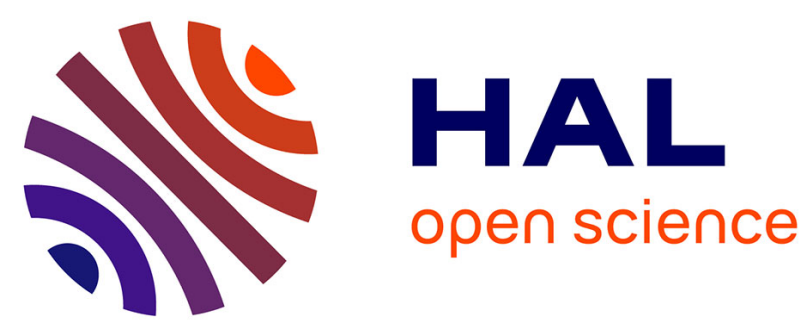

\title{
Farming in mediterranean France and rural settlement in the Late Roman and early Medieval periods: the contribution from archaeology and environmental sciences in the last twenty years \\ Aline Durand, Philippe Leveau
}

\section{To cite this version:}

Aline Durand, Philippe Leveau. Farming in mediterranean France and rural settlement in the Late Roman and early Medieval periods: the contribution from archaeology and environmental sciences in the last twenty years. Miquel BARCELÓ; François SIGAUT. The Making of Feudal Agricultures?, 14, BRILL, pp.177-253, 2004, The transformation of the Roman World, 90-04-11722-9. halshs-01052529

\author{
HAL Id: halshs-01052529 \\ https://shs.hal.science/halshs-01052529
}

Submitted on 28 Jul 2014

HAL is a multi-disciplinary open access archive for the deposit and dissemination of scientific research documents, whether they are published or not. The documents may come from teaching and research institutions in France or abroad, or from public or private research centers.
L'archive ouverte pluridisciplinaire HAL, est destinée au dépôt et à la diffusion de documents scientifiques de niveau recherche, publiés ou non, émanant des établissements d'enseignement et de recherche français ou étrangers, des laboratoires publics ou privés. 


\author{
BARCELÓ M. et SIGAUT F., (eds.), The Making of Feudal \\ Agricultures?, Boston-Leiden, Brill editor, coll. The transformation \\ of the Roman World, vol. 14, 2004, p. 177-253.
}

\author{
Aline DURAND (aline.durand@univ-lemans.fr)
}

Philippe LEVEAU (leveau.phil@wanadoo.fr)

\title{
FARMING IN MEDITERRANEAN FRANCE AND RURAL SETTLEMENT IN THE LATE ROMAN AND EARLY MEDIEVAL PERIODS: THE CONTRIBUTION FROM ARCHAEOLOGY AND ENVIRONMENTAL SCIENCES IN THE LAST TWENTY YEARS
}

\section{Introduction}

From the end of the $19^{\text {th }} \mathrm{C}$, French historiography has studied the period spanning the $5^{\text {th }}-10^{\text {th }} \mathrm{C}$ essentially along political and institutional lines. For Southern France, the sum of available information allows a brief overview. The Province of Gallia Narbonensis, created as a single administrative unit during the early Roman Empire, is first split up, as a result of Diocletian's reforms, at the end of the $3^{\text {rd }} \mathrm{C}$. These reforms lead to the creation of three new provinces: the Primary Narbonnaises (Narbonensis Prima comprising Narbonne, Béziers, Nîmes, Lodève, Uzès, Agde and Maguelonne), the Secondary Narbonnaises (Narbonensis Seconda with Aix-en-Provence, Apt, Riez, Fréjus, Gap, Sisteron, Antibes) in between which the Provincia Viennensis are inserted (the southern part of the latter, comprising Valence, Die, St-Paul-Trois-Châteaux, Vaison, Orange, Cavaillon, Avignon, Arles, Marseille, Carpentras being of interest here) (Rivet 1988). But the real divisions stem from the splitting up of the Roman Empire following the military crisis that ensued from the massive influx of Germanic peoples, Wisigoths in the South, Burgundians in the North, into the former Province. New political entities are being formed through the settlement of immigrants and through the gradual merging of the old Gallo-Roman population with the newcomers: Septimania and Provence on either side of the Rhône valley. Even though from the end of the $5^{\text {th }} \mathrm{C}$ the Francs achieve the unity of Gaul within the Frankish kingdom and later within the Carolingian Empire by removing Provence from the Burgundian kingdom, the two regions - Provence and Septimania - nevertheless remain peripheral to these political developments. The dissolution of the Carolingian Empire after $822 \mathrm{AD}$ results in the birth of two new feudal principalities: the county of Provence torn between its allegiance to the Carolingians on the one hand and the Burgundians who for a century consider Provence as a territory ripe for conquest on the other hand, and the marquisate of Gothia.

By contrast, the history of farming during this «period of transition» between the Roman Empire and the Middle Ages is rarely studied for itself. Several reasons can explain this situation. Amongst the main reasons figure the dirth of written documents even in a region generally better served than others. A number of written sources of considerable interest exist for the period of the end of the Roman Empire. Some, like the Theodosian code refer to the whole of the Empire. The imperial legal texts that it contains are to be used with caution, as illustrated by the debate surrounding the meaning of the expression agri deserti. This expression, coined for taxation purposes (Whittaker 1976), cannot be used to describe a real situation in settlement archaeology. Other texts provide local information, such as that given in the works of Gregory of Tours or Sidonius Apollinaris, or in Wisigothic documents 
Article published in BARCELÓ M. et SIGAUT F., (eds.), The Making of Feudal Agricultures ?, Boston-Leiden, Brill editor, coll. The transformation of the Roman World, vol. 14, 2004, p. 177-253.

or in the Lives of Saints. On the other hand, descriptive or financial accounts, compiled primarily for military or taxation purposes do not appear until the $7^{\text {th }}$ and $8^{\text {th }} \mathrm{C}$ with the two polyptychs of Waldade and Ansefred, advocatus of the Bishop of Béziers. At the very end of the $8^{\text {th }} \mathrm{C}$ royal and imperial proclamations of gifts or confirmations throw some light on rural Languedoc and Provence. It is only in the second half of the $10^{\text {th }} \mathrm{C}$ that diplomatic acts begin to form series coherent enough to shed light upon agricultural systems. Even so, the interpretation of these sources encounter problems, in particular of vocabulary. Thus it is hard to elicit the meaning of such key terms as aratrum (ard or plough) or frumentum (winter or spring cereals). To obtain a more complete picture of agricultural regimes, one must therefore turn to archaeology. But here the medieval period is less easily legible on the ground than the late Roman period: in surveys greater use of lime in masonry and the better quality of pottery favour the Roman period in comparison with the Early Middle Ages whose remains are difficult to trace. Therefore the Roman period is over-represented in relative terms. This bias is largely illusory but it combines with a miserabilist school of interpretation of often tenuous remains to reinforce the image of a period of decline experienced by the second part of the first millennium AD.

Some twenty years ago, J. Chapelot and R. Fossier berated the Mediterranean coast as the one region of Europe where, - with some notable exceptions, amongst which Provence - archaeological research in the rural environment was least advanced (Chapelot and Fossier 1980, 70). In fact, from that time onwards a fundamental change in the attitude of archeologists was beginning to take shape and is at the origin of much recent progress. P.-A. Février was already drawing attention, in the 1970s, to the strength of new research on settlement and population patterns, a research area he was particularly keen to encourage (Février 1978) and which he reviewed in the catalogue of the exhibition Premiers temps chrétiens en Gaule méridionale (Février 1986) At the same time, the traditional historical view of the Early Middle Ages as a Dark Age where people, driven to despair by recurrent famines due to very poor if not basic farming practices, were resorting to cannibalism was being challenged at the Flaran colloquium (1992). The way was open to a new more sophisticated reading of the documents and to a better integration of archaeological research, which itself was in the process of reorientation. These developments allow the breaking down of barriers between fields of research formerly artificially segmented into institutionalised chronological compartments. They open new paths which an increasing number of researchers are eager to take and, at present, the Ministry of Culture actively promotes archaeological research on the periods under discussion.

By definition, agriculture aims to model, adapt and transform a natural milieu to produce plant and animal products. The milieu under consideration corresponds to Mediterranean France, that is to say three old French provinces, Provence, Languedoc and Roussillon. Climate and soils, conditioning the development of agricultural regimes, are two key elements in the reading of the evidence and are used to define a sector whose northern limit is given by botanists and plant geographers as the limit of the spread of the olive tree, the mythical tree of Mediterranean civilisation. Temperate winters, hot and dry summers contribute to unite a region topographically very varied or even divided on either side of the Rhône: to the West plains and plateaux predominate and to the East basins and mountains of middle altitude prevail. As always in Mediterranean countries, the major characteristic is not so much the amount of annual rainfall - in the Camargue $450 \mathrm{~mm}$, in Nice $750 \mathrm{~mm}$ - but the arid conditions of the summer, necessitating irrigation and rendering cattle production very difficult. 

Brill editor, coll. The transformation of the Roman World, vol. 14, 2004, p. 177-253.

\section{I.- THE MILIEU AND LANDSCAPE DYNAMICS}

The question of the milieu has grown in importance during the last few years, particularly in archaeological studies of historic periods. By reinstating archaeological sites into their geomorphological and sedimentological context, soil scientists and geomorphologists have drawn the attention of archaeologists to the role of the climate in the destruction or post-depositional history of archaeological sites. A strictly deterministic approach showed its limitations and led to misinterpretations. Nevertheless, natural elements and processes have an influence upon the formation of land and their exploitation: stable, even inert or stagnating periods are followed by phases of innovation where technical advances or social and economic structures cross new thresholds. That is why we shall consider in some detail the results of an approach that can increase our understanding of agricultural activities and farming practices.

\section{1.- The question of general climate change}

It is generally accepted that the end of the Roman Empire saw a major deterioration in climate which contributed to depress living conditions and may have played a key role in the onset of an economic decline (Provost 1984). This correlation needs to be re-examined in the light of recent advances in our knowledge of climatic history, made possible through new dating methods such as radiocarbon dating and dendrochronology (Magny and Richard 1992). Historians have in the past tended to use the work of natural scientists to dress up «scientifically» a tradition strongly anchored in a messianic vision of early Christianity: the notion of a God-inflicted worsening of conditions in retribution for the sins of humanity was in tune with its time. Even though historic thinking has become more secular, historians have continued to see climate change as one of the factors in the decline of the Roman Empire: the consequent deterioration of living conditions would have been one of the causes for the great migrations. It is therefore necessary to review briefly the subject, while underlining the relative nature of the term «worsening» since we are dealing with a particular Mediterranean climatic zone where farming regimes are bound by heat and summer droughts. Obviously a drop in the mean temperature or an increase in rainfall do not have the same effect as in more northerly regions.

Collaborative research carried out by archaeologists, historians and environmentalists give a more trustworthy and subtle image of climatic conditions, that is to say the climatic context. Since written documents can only be used from 1396 AD (Alexandre 1987), when continuous and homogeneous series of records begin, a multidisciplinary approach is necessary. The data gathered refer to temperature and rainfall, i.e. two of the three parameters that define «the climate»; they were collected in the main along the northern margins of our study area. In brief, palaeoclimatologists have identified a cooling phase named «Göschenen II» which begins in the $3^{\text {rd }} \mathrm{C}$ and results in an advance of alpine glaciers at its peak in the $5^{\text {th }}$ to $7^{\text {th }} \mathrm{C}$. This cooling period begins in the Danube regions and the Alps in the first half of the $4^{\text {th }} \mathrm{C}$ and continues with the advance of glaciers around the middle of the $5^{\text {th }} \mathrm{C}$. The drop in summer temperature is estimated to be in the order of 1 degree $\mathrm{C}$ and heralds the end better climatic conditions which had enabled the spread of certain plants such as, in particular, the grapevine (Patzelt 1994). This sequence of events seems to be confirmed by observations made on the level of lakes in the Jura and subalpine regions (Magny 1992) and on tree-ring growth of larch trees (Serre 1979). This phase corresponds to a period coastal erosion resulting in a rise of the sea level along the North Sea coast between 250 and $700 \mathrm{AD}$ (formerly named «the second Dunkirk transgression»). A general warming period, coincidental with the Middle Ages proper, follows this cooler period. A small «climatic optimum», peaking around $1000 \mathrm{AD}$ continues until the $14^{\text {th }} \mathrm{C}$, which sees the onset of the Little Ice Age. These are of course general trends which, depending on the regions, can have greater or lesser effects upon agricultural production, the subject of our investigations. Particular caution is needed since the Mediterranean climate affecting our region is itself a climate of transition. This question has recently been addressed by the pollen specialist G. Jalut. His work shows that the Mediterranean climate developed gradually in the western Mediterranean during the Holocene period along a north-south latitude. According to Jalut, a change in the annual distribution of rainfall which resulted in the pattern of summer droughts characteristic of the Mediterranean climate took place between 3300 and 1000 B.P in a latitude zone located between $40^{\circ}$ and $44^{\circ}$ (northern latitude), i.e. in our 
Article published in BARCELÓ M. et SIGAUT F., (eds.), The Making of Feudal Agricultures ?, Boston-Leiden, Brill editor, coll. The transformation of the Roman World, vol. 14, 2004, p. 177-253.

study area (Jalut et alii, 1997). The onset of summer droughts in the Golfe du Lion is dated to 2600 - 1900 B.P (2850 - 1630 cal. B.P) (Jalut et alii, 2000) (contra : Pons and Quezel 1998). In the Languedoc and Roussillon, the climate sequence has been refined thanks to a series of measurements on the variation of $\delta^{13} \mathrm{C}$ carried out on Mediterranean deciduous oak charcoal from prehistoric and historic contexts (Vernet et alii, 1997). Indeed if the weather is too dry, plant stomata close up, inhibiting the exchange of gas through photosynthesis, i.e the fixing of carbon in lignite, the constituent of living wood. Although further observations are needed, these results already point to a date around 3000 B.P for the greatest extent of summer droughts. The construction of a Holocene curve of variations in the isotope of oxygen $\delta^{18} \mathrm{O}$ from stalagmites in the cave of Clamouse near St-Guilhem-le-Désert in the middle valley of Hérault (MacDermott et al. 1999) also reveals the return to warmer and /or drier climatic conditions - without is being possible to determine which - from around 3000 B.P: the correlation between the isotopic variations and the behaviour of stalagmites is particularly well documented in this cave and therefore an interpretation along climatic lines is permissible.

These hypotheses must be compared with observations that suggest that during the Roman period rainfall patterns were more regular. For the northern Alps and the Jura, it is now possible to consult the work carried out on the lakes of the Jura and the lake of Paladru in the department of Isère. Archaeological research conducted by M. Collardelle and E. Verdel allow the reconstruction of a climatic sequence dating to the end of the Early Middle Ages. The period preceding $1000 \mathrm{AD}$ is characterised by a «dry» phase which archaeologists suggest was an essential factor in the establishment of a community on the edge of the lake of Paladru (Borel et al. 1996). Work carried out on river levels and on the formation of water basins in the lower Rhône valley has recently extended our understanding of climatic conditions. This research examines rainfall regimes through measuring the river water debit. A combination of morphological, sedimentological and archaeological information has allowed riverine milieux to be better defined in our region. It is only during the transition phase between the late Roman and the Early Medieval period that a major hydraulic crisis, capable of affecting river environments in a fundamental way, can be detected. Whereas during the millennium that comprises the later Iron Age and the Roman period, that is to say the period bracketed between the $5^{\text {th }} \mathrm{C}$ BC and the $5^{\text {th }} \mathrm{C} \mathrm{AD}$, hydro-sedimentary activity had not caused any major modification of the water courses, the latter undergo, during the three centuries that run from the end of the $5^{\text {th }}$ to the end of the $7^{\text {th }} \mathrm{C} \mathrm{AD}$ major transformations such as braiding of the water courses or modification to the delta. Noticeable from the end of the Roman period, this development signifies an increase in the liquid and solid volume carried by the water courses and this is undeniably due to a climatic component (Provansal et al. 1999). A wetter climate phase starting around the $2^{\text {nd }} \mathrm{C}$ is due to last into the beginning of the Middle Ages proper, when conditions become drier again. In a comparative study of the sedimentary stratification from two rock shelters, Font-de-l'Oule near Fontaine-de-Vaucluse in the Rhône valley and Font Juvénal near Carcassonne, J.-L. Brochier notes a first cold spell around 450-700 AD and a second one corresponding with the Little Ice Age. The lack of sedimentary deposition during a period spanning the $7^{\text {th }}$ to $12^{\text {th }} \mathrm{C}$ undoubtedly corresponds, given the palaeoclimatic data, to a temperate period which Brochier ascribes to a «dry tendency». Indeed conditions become more humid from the $13^{\text {th }}$ C onwards (Brochier 1983).

\section{2. - Climate, agriculture and the rhythms of erosion}

Erosion, which in our time scale refers to superficial erosion, is the physical process where the effects of the climate on the landscape are most readily observable. Rainwash carries sediments towards the bases of slopes which are then built up into river terraces and which are accumulated downstream in river mouths before ending up in marine deposits. These formations depend on petrology and on climate. In the absence of human intervention, the rhythm of the erosion that affects them (slowing down or speeding up) depends on two factors that define the climate: rainwater that causes the sediments to move and vegetation that protects soils from the impact of rain and stabilises them on slopes. However, since the beginning of the Holocene, one must add anthropogenic causes to climatic causes.

During the last century, foresters engaged in the fight against torrential rains emphasised the relationship existing between the latter and forest clearances caused by the increase in agricultural exploitation and by the need for fuel. In historic times, but particularly in the $19^{\text {th }} \mathrm{C}$ hillwash had torn from hill slopes and Mediterranean mountain sides huge amounts of sediments which built up in lower valleys, coastal plains and deltas. These accounts were corroborated by the work of geomorphologists who had proposed a more subtle analysis of alluvial deposits 
Article published in BARCELÓ M. et SIGAUT F., (eds.), The Making of Feudal Agricultures ?, Boston-Leiden, Brill editor, coll. The transformation of the Roman World, vol. 14, 2004, p. 177-253.

than those presented in geological maps of the «recent Quaternary». The late 1960s saw the work of C. Vita-Finzi on alluvial valleys around the Mediterranean during the Quaternary. The model that Vita-Finzi put forward gave precedence to natural causes, that is to say the climate (Vita-Finzi 1969). But, following on from the concept of anthropisation, other models have emphasised the social causes of erosion (Neboit 1991). The latter are of great interest to historians enabling them to detect within the rhythms of erosions precious pointers, in regions and periods where documents are rare, to the impact of agricultural systems.

This approach has been followed in Provence since 1985, when research on historic periods by geomorphologists from Aix-en-Provence was conducted in collaboration with archaeologists and historians in the neighbouring hill regions. First, research concentrated on hills to the East of the Etang de Berre, a lagoon formed by the retreating waters of the Holocene: boreholes through sedimentary deposits enabled the rhythms of erosion in the basins of a small number of water courses to be charted. This work has led to the definition of regional rhythms corresponding to developments in agriculture and fluctuations in the climate. A first erosion «crisis» initiated at the beginning of the Subatlantic lasted into the early Iron Age. By contrast, the Roman period is characterised by a very small amount of sedimentary deposition. Beyond, a second crisis results in the establishment of a second alluvial blanket, noted on the principal river terraces and in the foothills. The Little Ice Age and the population explosion of modern times are held jointly responsible for this alluvium (Provansal 1996). In fact the data show a great range of situations given by natural factors - petrology and slope - as well as anthropogenic causes. For the massif of the Sainte-Victoire, M. Jorda concludes that «the sum of erosion during the last two millennia seems modest in spite of the delicate nature of the milieu and contours seem to have changed little since protohistoric times» (Jorda and Mocci 1997, 227). By contrast, the situation is vastly different in the northern and southern foothills of the Alpilles where detailed research by H. Bruneton (1999) concentrated upon the post-Roman accumulation of deposits on archaeological sites. The site of Glanum, located at the base of a talweg and on its northern slope, was fossilised by a sedimentary blanket that could reach a depth of 4 to $5 \mathrm{~m}$. Further, there are colluvial fills which, though not deep, cover most of the piedmont (Bruneton 1999, 150).H. Bruneton reaches the following general conclusion in his study: «the widespread nature of post-Roman deposits in talwegs and their very frequent association with colluvial pockets represents a new facies which it is possible to attribute to increased pressure of agriculture on slopes, whatever the fluctuations in population or the settlement densities might be» (ibid., 168). However, a detailed picture is a complex one: in the hollows formed on the archaeological site of Saint-Blaise on the western side of the Étang de Berre «stratigraphy shows rather a series of erosion incidents, separated by episodes of arable land» (Provansal 1996) (Leveau et al. 2001 in press).

One must therefore turn to soil science to extend our understanding in a more refined way. First among such studies were the works of P.Poupet and then J.-F. Berger who both cooperated with archaeologists. Though following different lines of enquiry the results obtained converge. P. Poupet carried out detailed studies on the nature of the soils of eastern Languedoc, their possible depletion caused by agricultural exploitation, their preservation and the possibility to trace agricultural practices on soils that were subsequently suddenly covered. His research targeted two micro-regions in particular, the Vaunage and the flanks of the Garrigues in the Nîmes area. The Vaunage consists of a small depression, some $10 \mathrm{~km}$ from Nîmes and some $25 \mathrm{~km}$ from the sea. It is drained by a tributary of the Vistre, the Rhôny, which springs to the North-East of the Vaunage and is $12 \mathrm{~km}$ long. The region is the subject of a number of investigations into its protohistoric, Roman and medieval past. Whereas it used to be thought, in the 1970s, that the region had been stabilised early on by a system of terrace cultivation dating to protohistoric times (Sapin 1981), it became apparent, just as it was becoming apparent elsewhere, that the visible landscape was not an ancient landscape (Ginouvez et al. 1990, 389-393). A section observed near Saint-Dionisy «shows that before the Roman period the slopes below the oppida of Viou and Nages-les-Castels were stable». Its cultivation before protohistoric times is discounted. In fact it is after the Roman period that there began a series of soil management cycles and of levelling of the slopes (Poupet 1999, 135 and fig. 14b). The effects of erosion vary tremendously. Thus, whereas shallow (less than $1 \mathrm{~m}$ thick) deposits smother the foothills of La Liquière, substantial post-Roman colluvial deposits can be seen at the foot of Roque-de-Viou. These observations have been extended to the eastern fringes of the Garrigues of Nîmes, where P. Poupet has studied the evolution of the slopes and piedmont above the river Vistre. There are of course areas of cover, but on the whole they are not substantial. In certain areas, the level of ancient fields has even been totally stripped.

Further North in the Valdaine, the work carried out by J.-F. Berger has resulted in a series of publications from which we have extracted information concerning the period under study. This hilly region is located on the left bank of the Rhône to the East of Montélimar and occupies circa $300 \mathrm{~km}^{2}$. Drained by two tributaries of the Rhône, 
Article published in BARCELÓ M. et SIGAUT F., (eds.), The Making of Feudal Agricultures ?, Boston-Leiden, Brill editor, coll. The transformation of the Roman World, vol. 14, 2004, p. 177-253.

the Roubion in the North and the Jabron in the South, it consists of a series of hills and sandstone-marl plateaux with changes in levels ranging from 250 to $450 \mathrm{~m}$. During the Holocene, a very active period of morphogenesis has resulted in a rounded topography. In spite of the continuing erosion of the slopes causing deep alluvium in the talwegs, the sedimentary deposits have become stabilised by a permanent vegetation cover during the second half of the first millennium Ad (Berger 1997, 115-117). For the period spanning the $4^{\text {th }}$ to $10^{\text {th }} \mathrm{C}$ the soil, charcoal and mollusc analyses carried out by S. Thiébault and F. Magnin conjure up an open vegetation along forest edges or hedges (Berger 1995, 105). By contrast a brown soil formation in the plains and foothills demonstrates that a period of hydrological calm followed a period of greater hydrological activity. But the drainage networks that allow the development of agriculture are abandoned: the data provide by molluscs indicates wet meadows and marshes where fields were once cultivated. A period of several centuries, in which slopes were able to stabilise, allowed the soil cover to become structurally more stable and to reach a high level of organic matter which was to be of benefit to the medieval society that came to exist after $1000 \mathrm{AD}$.

\section{3. - Sedimentary build-up: coastal plains and river terraces}

The relatively stable nature of slopes (upland zone) does not preclude substantial sedimentary build-up on major river terraces and on coastal plains (lowland zone). Though of small extent at a regional scale, these deposits are of particular interest to farmers at a local level since the grey alluvial soils that make up these surfaces give cultivation soil of good quality, kept fertile by the adjunction of silt from flooding. Their cultivation presupposes a strong degree of water management. As they are very sensitive to summer droughts, these soils need to be irrigated. It is also necessary to drain them to eliminate standing rainwater and to lower the level of the water table. Flooding does no harm provided the ditches that allow floodwaters to recede and stop the water table from rising are kept in good order. During periods of environmental crises, saturation on alluvium quickly results in the abandonment by farmers of low-lying land.

The construction, in 1996, of a new TGV line in the Rhône valley between Valence and Orange allowed new research to be commissioned. These have confirmed the predicted extent of sediments which, since the Roman period, reaches a depth of 1 to $3 \mathrm{~m}$ and even $3.50 \mathrm{~m}$ in the plain of Orange (Brochier 1997, 95). These sedimentary deposits have masked the old «corrugated iron» land surfaces (id. 94). J.-F. Berger and C. Jung have concentrated on the hydrological conditions prevailing in these sedimentary deposits and on the relationship between the control of water flows and agricultural exploitation. They were able to identify a stable period dating from the end of the $3^{\text {rd }}$ or early $2^{\text {nd }} \mathrm{C} B C$ to the end of the $1^{\text {st }} \mathrm{C} \mathrm{AD}$ (Berger et al. 1997, 150), in which a marked slowing down of alluviation had allowed soils to regenerate. The agricultural conquest of the flood plains took place at the time of the establishment of the Roman centuriation system of Orange. Later, starting at the end of the $1^{\text {st }} \mathrm{C}$, there begins a «major hydrological crisis» which entails a rise, estimated to be between 50 and $80 \mathrm{~cm}$, in the river beds as well as an increase in the amount of sedimentation in the southern Tricastin at north of Avignon and in the plain of Orange (3$4 \mathrm{~mm}$ per year). From the late $5^{\text {th }}$ and early $6^{\text {th }} \mathrm{C}$ to the $7^{\text {th }}$ and $8^{\text {th }} \mathrm{C}$, that is to say during a climatic phase known to have been humid throughout Europe, there are no more controls over water drainage, nor over the disposal of sedimentary deposits, nor over their admixture to arable land: several dozen centimetres of floodwater silt can be seen sealing abandoned ditches. A fallow period begins, a phenomenon whose social nature J.-F. Berger draws attention to. But the hydromorphology of the soils observed in sections dating to the end of the $2^{\text {nd }} \mathrm{C}$ is not irreversible. Between the end of the $3^{\text {rd }}$ and the end of the $5^{\text {th }} \mathrm{C}$ the drainage networks connected with the centuriation system are restored and enable the control of alluviation; soil formation is allowed to restart. However, when, from the end of the $5^{\text {th }} \mathrm{C}$, ditches are no longer cleaned out marshes develop. Thus natural factors such as a climatic crisis are compounded by a political crisis. Husbandry would then have grown in importance according to J.-F. Berger.

Information concerning the coastal zone is uneven, in spite of collaborative research between archaeologists and geomorphologists. To the East of the Rhône, on the lower reaches of the river Argens, research is in its initial stages. Two borehole sondages, one upstream from the ria, the other $5.2 \mathrm{~km}$ to the East, i.e. about half-way from the present coast line, have allowed M. Dubar to propose a provisional reconstruction of the rhythms of growth of the shoreline and of filling up of the ria. He notes the depth of reddish silts cut into by the present river bed. These 4 to 5 $\mathrm{m}$ thick deposits represent reddish clays washed down from the flanks of the massifs of the Maures and Esterel; erosion has caused a an alluvial cone to build up between the $5^{\text {th }} \mathrm{C} \mathrm{BC}$ and the beginning of our era, which means 
Article published in BARCELÓ M. et SIGAUT F., (eds.), The Making of Feudal Agricultures ?, Boston-Leiden, Brill editor, coll. The transformation of the Roman World, vol. 14, 2004, p. 177-253.

that «access to the port of Fréjus has to be provided by an artificial channel» (Fiches et al. 1995, 210). But the reconstructions proposed are based on a mathematical model which assumes a constant rate of sedimentation taking into account neither fluctuations in climate nor social pressure. Situated between Provence and the Languedoc, the lower Rhône plain and the Camargue have been studied for the light they can shed on the dynamics of the river and the history of the delta. The blanket coverage of alluvium explains why archaeological distribution maps do not reflect the density of occupation in ancient periods. The effects of flooding and of dynamics specific to the formation of the delta are compounded. In the plain of Arles, sedimentation is estimated to have grown by c. $2.5 \mathrm{~m}$ since the Roman period outside the areas near river banks where it is obviously deeper. The port of Aigues-Mortes at west of the Rhône delta was cut off by alluvium from the river during the Middle Ages. To the West in the Languedoc, the coast is characterised by extensive marshy plains and marshes whose history is linked to the coastal rivers that bring deposits with them. As a result, despite the rise in sea level in the last two millennia (Ambert 1986; Ambert 1995, 432), the sealing off of lagoons is inconsequential when the rivers that flow into them are low but rapid when rivers are high. The difference between two neighbouring stretches ow water, the Etang de Thau and the Etang de l'Or (or of Mauguio) illustrates perfectly this state of affairs. At present, the Vidourle, a small coastal river of some $70 \mathrm{~km}$ in length, flows directly into the marshes of the Petite-Camargue. But up to recent times it flowed into the Etang-de-l'Or which is now almost completely filled in by the rivers Vidourle, Vistre and Radelle (Ambert 1986). The fragile nature of the marshes and their movements have important implications in terms of salinity and exploitation of natural resources. Documents from Psalmodi of the $9^{\text {th }}$ and $10^{\text {th }} \mathrm{C}$ indicate, through the precision of their descriptions and vocabulary, that there was a clear knowledge of the landscape and of land reclamation at an ancient date. In the $11^{\text {th }} \mathrm{C}$, the Bishop of Maguelonne orders a new salt marsh to be opened to replace the old «grau sarrasin» whose access had become difficult. Further West the demise of the old port of Narbonne is linked to the build up of soil by the river Aude: its present volume is estimated to be in the order of $1800 \mathrm{~m}^{3}$ per year (Ambert et al. 1993, 129-130). The present lower course of the river is totally artificial, having been corrected and managed after the floods of the $14^{\text {th }} \mathrm{C}$ and the great flood of 1755 . In all the cases cited, though the general sequence has been identified, the rhythms of fluctuations have not yet been recognised precisely. The character of the coastal region remains elusive beyond the $17^{\text {th }} \mathrm{C}$, when map evidence becomes available to reconstruct the coastline. The precise impact of the crisis of the $6^{\text {th }}$ and $7^{\text {th }} \mathrm{C}$ should become better understood thanks to current research on the wetland zones and the valley of the Aude, where borehole surveys have been carried out by P. Ambert and by J. Guilaine (1995).

\section{II.- THE CONDITIONS OF FARM PRODUCTION}

Straddling traditional historical periods, the period spanning the $3^{\text {rd }}$ to the $10^{\text {th }} \mathrm{C}$ is split between a dying Roman Empire and a yet unborn Frankish kingdom. This situation has earned it the definition of an inevitably obscure transition phase, between the high points of two different socio-economic systems. It can therefore neither have its own dynamic nor offer conditions which would favour an expansion in farming. Given the weight that such a historic tradition carries, let us briefly review its main lines. Indeed, gaps in our knowledge have given rise to vast historic narratives, sometimes brilliantly told, which even today still hold sway. They are beginning to be revised in the face of so much contradictory evidence. Two areas are particularly significant: on the one hand economic and commercial exchanges which benefit from two interesting data sets, pottery and coin evidence; on the other hand the mastery of energy sources, indicative of the history of technology.

\section{1. - Exchanges}

For Henri Pirenne, the great divide in the Medieval western world was not the migration of «barbarian» peoples at the beginning of the $5^{\text {th }} \mathrm{C}$, but the migration of the Saracens: trade and economic relations between East and West would have remained active up to the time of Arab expansion. Muslim piracy would have led to the failure of these relations and the death of the Christian western Mediterranean world. Sometimes taken to extremes, this thesis, which emphasises the break of the $7^{\text {th }} \mathrm{C}$, has been rejected by historians for several decades. In the absence of a great corpus of written documents, recent archaeological research can contribute new information to the economic 
Article published in BARCELÓ M. et SIGAUT F., (eds.), The Making of Feudal Agricultures ?, Boston-Leiden, Brill editor, coll. The transformation of the Roman World, vol. 14, 2004, p. 177-253.

question. It allows us to qualify over-simplistic schemes by pointing out the complexity of economic phenomena. It also gives the opportunity to approach the question at different levels, in particular local and regional levels.

Pottery, a favoured indicator of change, has been the subject of new studies completely revising the question of the opening of Provence and Languedoc to commercial currents. Paradoxically from the $4^{\text {th }} \mathrm{C}$ onwards, ceramic evidence allows us to trace a curve, from a $1^{\text {st }} \mathrm{C}$ base, which shows increasing exchanges and the number of sites denoted by pottery show that land occupation is at its peak at this time. Ceramic imports have substantially increased compared to local pottery production. Imports only begin to decline in the $6^{\text {th }} \mathrm{C}$, a century which saw the end of the great Mediterranean market (Février 1986; Raynaud et al. 1990, 289-299 and 1996). But this decline is not simultaneous everywhere: evidence for solid commercial relationships exists for Marseille up to the $7^{\text {th }} \mathrm{C}$, whereas in Arles or Narbonne they can only be traced up to the $5^{\text {th }} \mathrm{C}$ (Villedieu 1986, 182-183). Between the $7^{\text {th }}$ and $9^{\text {th }} \mathrm{C}$ this trend, identified by A. Parodi and C. Raynaud in their research on the Vaunage (Parodi et al. 1987), is characterised by a change in pottery repertoire where «grey pottery predominates, pottery forms in the Gallo-Roman tradition disappear and Mediterranean imports cease». They also note that this trend does not prejudice the intensity of interregional relations. Other recent pottery studies follow similar lines (Lenhardt et alii, 1993). The first truly medieval pottery tradition can only be clearly perceived from the $7^{\text {th }} \mathrm{C}$ and $8^{\text {th }} \mathrm{C}$, when regional workshops such as Masmolène start production and prelude the great tradition of regional pottery production that lasted right into modern times. Yet a break in imports and an evolution of indigenous productions does not imply a stable system: mapping of microregional distribution zones shows that the Early Medieval economy was not a mere subsistence economy.

The study of coins from excavations has shown that small and medium coinage continued to be used well after minting stopped in the Merovingian period: «numismatists have evidence that the currency which was no longer available to regular administration was nevertheless in use for far longer than could be supposed, at least until the Ostrogothic period» (Brenot 1998, 361). Byzantine bronze coinage makes an appearance in Provence and the Languedoc. Ancient coins continue in use and are copied by overcasting. Nevertheless a break in the monetary economy occurs in the $7^{\text {th }} \mathrm{C}$. Copper and bronze were already no longer used at the end of the $6^{\text {th }} \mathrm{C}$. At the end of the following century, around 675-680, the Merovingian mints of Arles and Marseille cease to mint gold coinage. Silver is left as the only metal used for coinage until the first gold issues of Saint Louis (Brenot 1986, 197-199 and 1996, 147-160).

\section{2. - The mastery of energy sources}

From the oldest (Duby 1962) to the most recent, all the syntheses dedicated to farming in the Early Middle Ages emphasise the poor means of which the peasantry disposes for cultivating the land: primitive tools, «hardly any iron», «poor quality and badly selected stock» (Chapelot and Fossier 1980, 24-25). Fortunately, archaeology allows a re-evaluation of such notions. The situations that archaeology highlights, in the history of water mills and in the light of more and more frequent finds of metalworking from sites, go against the received notion of a technologically backward period. But this state of affairs does not preclude the upkeep of techniques that go back to the earliest days of farming, evidenced by the data on manuring (see below). For the time being, the diversity of real situations is striking.

\section{a. - The water mill question}

Recent years have seen much progress in the archaeological identification of water mills, a structure that occupies a key place in the mastery of natural sources of energy. Since the work of M. Bloch (Bloch 1935), the historiography of mills has been marked by the notion of a blockage in techniques with a society that relied on slave labour. Mills would only have come into general use during the Middle Ages. Undertaken by F. Benoit during the 1940s, the excavations of the mills of Barbegal near Arles seem to have given archaeological credence to such a theory. It appears that the mills were built at the end of the $3^{\text {rd }} \mathrm{C}$ and were in use until the end of the $4^{\text {th }} \mathrm{C}$. The dating was based upon observations of building techniques seen on the aqueduct bridges of the valley of the Arcs and on excavated finds, in particular coins. F. Benoit saw the mills in a wider economic and historic context (Benoit 1940). 
Article published in BARCELÓ M. et SIGAUT F., (eds.), The Making of Feudal Agricultures ?, Boston-Leiden, Brill editor, coll. The transformation of the Roman World, vol. 14, 2004, p. 177-253.

Accordingly, the abandonment of the mills was due to an economic decline following the barbarian invasions. The dating suited social historians and historians of techniques and, quickly, the mills became a symbol: the construction of these mills constituted a response of the Roman economy to the decline of slavery. Unable to force men to carry out work that was considered the hardest of labours, Roman society would have turned to technology and would have tried to substitute human labour with natural energy sources.

New discoveries were to be expected: Palladius recommends the use of the outflow from bathhouses to drive water mills, a recommendation that would suggest that this sort of arrangement was commonplace in villae (De agricultura I, 41). New excavations at the site of the mills of Barbegal has caused the dating of this structure to be revised: earlier by a century and a half, the construction of the mills goes back to the second quarter of the $2^{\text {nd }} \mathrm{C}$ (Leveau 1996). At the same time greater attention given to this type of structure has revealed that mills were more common than once thought. R. Royet had excavated an early Roman mill with vertical wheel outside the baths of the villa of Vernai in Saint-Romain-de-Jalionas to the east of Lyon (Royet 1995 and 1996). In the department of the Var, excavations by M. Borréani and J.-P. Brun have led to the identification of two mills, at the sites of the villae of Mesclans and Laurons at Les Arcs-sur-Argens (Borréani and Brun 1998). In the same region, the site of Saint-Martin at Taradeau provides a good example of the transformation of a water basin into a reservoir for a horizontal wheel driven mill (Brun 1999, 770). No doubt the list will grow. Between Arles and Barbegal, at La Calade (Amouric et al. 2000), a rescue archaeology project has led to the discovery of a turbine mill dating to the late Roman period. Similarly at the site of a villa of Vareilles at Paulhan on the Hérault, work on the A75 motorway has unearthed two mills of the $1^{\text {st }} \mathrm{C}$ AD, superceded by a third, larger mill (Mauné 1999). Similar discoveries have been made elsewhere, in North Africa (Wilson 1995) and in Portugal (Carvalho-Quintela et al. 1999, 214).

In Catalonia and in the Languedoc, where written documents are more frequent than in Provence, the first mentions of mills allow to put down some pointers to the history of the use of hydraulic energy during the early Middle Ages. In the Roussillon, the distribution of water mills leads S. Caucanas (1987) to conclude that water mills are neither rare nor isolated elements in the Carolingian landscape. Similar results have been obtained in the plains of the Languedoc: there the extremely wide geographic spread of the first mills dated to the $8^{\text {th }}-9^{\text {th }} \mathrm{C}$ shows that all running water courses, even standing water, were tried and put to use (Durand 2001). Current historiography thus asks afresh the question of the appearance of water mills and its spread between the Roman period and the year 1000, by investigating its mechanism and technique in a precise regional context, without generalising by trying to establish a link between the establishment of landlords and farm machinery (Comet 1999). In this perspective, the question of the chain of elements is of utmost importance; in the end, what use is made of the milled product? The gradual takeover by cereals of the farmers' diet, which took place some time between the $5^{\text {th }}$ and $8^{\text {th }} \mathrm{C}$, may provide a partial answer.

\section{b. - Iron metallurgy}

Iron is readily found throughout Europe but its frequent association with other metals makes it necessary to purify it in an operation that is technically delicate. Consequently, rural historians traditionally describe the early Middle Ages as a period where iron is scarce and inefficient tools are made mostly of wood. This point of view was made popular by G. Duby and has largely contributed to our pessimistic view of rudimentary farming techniques and of a little developed agriculture with a low output of hardly double the seeded input (for each sown grain only one or two grains were harvested). This thesis was founded both on historical (Duby 1962, 71-87) and archaeological sources. Indeed Carolingian tax inventories, including the well known example from Annapes, mention very few iron tools, and up to recently, archaeological finds of iron objects or tangible and frequent evidence for ironworking (forges) in the country was rare (Pesez 1991). Re-interpretation of polyptychs, in particular southern ones like the Brescia one, shows that iron is indeed present, if not plentiful, and that the traditional view can no longer be held. In the last decade, J.-M. Pesez and other archaeologists have drawn attention to the fact that negative evidence does not necessarily mean a real lack of iron: it could have been collected and re-used (Pesez 1991). Protohistorians, who tend to propose older dates, go even further: according to them, technical progress goes back well before the Middle Ages and they suggest the abandonment of the notion that Iron Age tools had remained at an archaic stage. In a development of an idea put forward by J. Kolendo in respect of Roman agriculture, P. Poupet notes, in the context of the protohistoric site of Ambrussum, that the scarcity of metals is linked to the cycle of re-use and re-shaping of tools 
Article published in BARCELÓ M. et SIGAUT F., (eds.), The Making of Feudal Agricultures ?, Boston-Leiden, Brill editor, coll. The transformation of the Roman World, vol. 14, 2004, p. 177-253.

(Poupet 1989, 264). Current investigations that follow this avenue of enquiry are leading to a complete reappraisal of traditional opinion. Thanks to rescue archaeology, early medieval settlements are beginning to become better known, when previously knowledge had been confined to just two sites: Larina in the higher Rhône valley in the southern zone and Brébières in the department of Pas-de-Calais in the northern zone. Iron slag, forges, charcoal kilns and other iron scrap are nearly always recovered from rural settlement sites (Bilans archéologiques régionaux).

F. Trément explains in his book on the occupation pattern around Saint-Blaise (on the western side of the Étang de Berre) that, although he took account of iron slag only in the last phases of his survey, his results show that forges and smithies engaged in the manufacture and repair of small agricultural tools are evident: 34 such sites have been identified. On one of these sites, seven areas of high density of slag coincide with settlement evidence for a hamlet. In the absence of excavation, this activity cannot be dated precisely, but Trément observes that the greatest part of these sites were occupied in the late Roman period (Trément 1999 a, 195). A few kilometres to the East and this time in an excavated context, ironworking on the site of la Pousaraque at Gignac has been identified by F. Gateau $(1997,16)$. These are but a few pointers in a region where remains of metalworking are frequent on ancient sites, as is shown by consulting the Archeological Map (Sites and Monuments Records) under the heading «slag». Once alerted, it is noticeable that forges or smithies are frequently reported in late Roman settlement or villa excavation reports. Amongst published sites, settlements at Lunel-Vieil (Raynaud 1998) or the Camp-de-César at Laudun above the right edge of the Rhône at nord-west of Avignon in the $5^{\text {th }} \mathrm{C}$ at least (Goury 1997, 166) or villae sites in their ultimate phases of occupation such as Près-Bas on northern side of the Étang de Thau (Pellecuer 1998), Sauvian/La Domergue near Beziers (Ginouvez et al. 1998, 182-3), dated to the second half of the $4^{\text {th }} \mathrm{C}$ at the earliest, at La Ramière (Maufras et al. 1998, 210-221) and Mayran (Buffat and Petitot 1998) in the east of the department of the Gard or at Les Bruns on the south-west side of Monts du Ventoux in Provence. These relatively frequent and recent indications give support to the hypothesis that negative evidence results from a lack of prospection. Thus the small number of slag-producing sites - some twenty amongst the 300 surveyed by S. Mauné in the valley of the Hérault - is probably explained as a problem of visibility (Mauné 1998).

Based upon an enormous and painstaking amount of survey that now needs the support of excavated evidence, V. Izard's thesis, dedicated to the Mediterranean Pyrenean mountains, demonstrates masterfully the role of iron prior to the year 1000. By tracing the diffusion of iron and technical advances in the art of the blacksmith, she shows the excellent quality of Catalonian iron and puts forward the idea that iron metallurgy plays a fundamental, hitherto unsuspected but never so clearly illustrated, role in the onset of the medieval process, and this from the Carolingian period onwards. This truly iron based civilisation reveals a new mountain civilisation, an anthropological system based not on pastoralism but on metallurgy (Izard 1999). Such a situation implies that finished metal products are plentiful and exported all over the South. Similarly, historians and archeologists engaged in the study of castels and "incastalamento" in the Languedoc, emphasise more and more the control of mines and their chains of production to explain the introduction of certain fortified places and the existence of veritable networks of power. These considerations appear to play a major role in the process of compartmentalisation ("encellulement") of people, underestimated until recently (Amado 1977; Journot 1990, Darnas 1998). This array to indications and of converging results points to the existence of a very developed and very early mastery of iron craftsmanship, if not metallurgy. During the 1997 Flaran colloquium dedicated to village craftsmen, the overview by M. Arnoux and the review by C. Verna of the western southern zone endorsed this point of view (Mousnier 2001). 


\title{
III.- PLANT ENVIRONMENT AND AGRARIAN SOCIETIES
}

\begin{abstract}
G. Bertrand wrote in 1975 that «the historic interpretation of the natural world in its relationship with agrarian structures and societies remains the most ill-understood problem, most rarely tackled and above all most illdefined in the whole of rural history» (Bertrand 1975, 38). Since, an increasing number of palaeoecological analyses are beginning to restore the ecological dimension within the history of farming societies. Palaeobotanical data allow us to trace in broad lines the anthropisation of the plant landscape, that is to say the opening of the environment to, and the development of species that appear in relation with agriculture and the need for fuel for domestic purposes and for craft or industry. Generally speaking, forest clearance episodes are characterised in pollen assemblages by a fall in the tree pollen curve. But it is yet early days for the construction of a general picture giving the regional fluctuations of such a history of clearance. Indeed, up to now in France, pollen specialists have mainly been interested in older periods and have paid little attention to historic periods, as shown in a survey by Jalut in 1991 (Jalut 1991, 360-1) of sites that have been sampled. Similarly in 1993, M.-C. Marinval-Vigne et S. Thiébault (Marinval-Vigne and Thiébault 1996), in their review of palaeoecological studies carried out throughout the French territory, note the lack of analytical data, thus prohibiting in-depth syntheses. However, the number of such studies has grown appreciably in the last ten years, though important regions remain on the fringe. The reasons behind such a situation are to be sought partly in the late start in French archaeological research, partly in the inclination of palaeobotanists to study climate history rather than agriculture.

The approach adopted here consists of an attempt to sequence written, archaeological and environmental data. Palynologists who have been concerned mainly with environmental change have made use of cultural features or agrarian features to date events in pollen sequences, but have rarely used written historical documents. Natural biologiste or scientific have been engaged in research on ancient landscapes, most often within the boundaries of climate research. Inevitably these scholars were led to work with prehistorians, but also with archaeologists and historians studying the more recent past. Amongst leading laboratories, let us mention the Laboratoire «Paléobotanique, Environnement et Action de l'Homme» at Montpellier, the Institut Méditerranéen d'Ecologie et de Paléoécologie at Marseille and the geomorphologists of the Institut de Géographie and the CEREGE at Aix-enProvence.
\end{abstract}

\section{1. - Indicators of cultivation}

Palaeoecology no longer contents itself with just providing lists of species for historians or archaeologists: it brings precious information on the character of the vegetation cover which reflects changes in the economic orientation of societies. In principle, these vegetation dynamics are often regressive in our climates: farmers clear forests or craftsmen exploit them to obtain fuel for heating mines and above all for ovens or furnaces. This evolution is obviously speeded up when the needs of urban markets for farm produce and craftsmen's products greedy in fuel are taken into account. During the Roman period urbanisation increases the need for building materials (timber, lime and fired materials), for heating public baths and for manufacturing pottery vessels.

In the coastal region - an unstable milieu and therefore sensitive to change -, in Provence, in the lower Rhône valley and in the Languedoc, recent work on charcoal and pollen analyses enable us to follow the sequence of human pressure on the vegetation and its effect on the landscape at the end of the Iron Age. At the foot of the massif of the Alpilles, in the Vallée-des-Baux, the Subatlantic phase is characterised by a drop in forest taxa (deciduous oak or pine) and the appearance of cultivated taxa, whose persistence indicates farming activity (Andrieu et al. 2000, 58). This activity, to which we shall return later, does not however exclude the re-growth of forests, though the latter remains difficult to date (Riera i Mora 2000,369-370). In general, however, palaeoecological data contribute to a more sophisticated image of the region during the early Middle Ages. Of course there is no denying the importance of water nor the impact of the break in cultivation in the medieval landscape around Arles. The abbey of Montmajour emerges from the marshes, which its monks manage, like an island (Stouff 1993). Pollen diagrams do not register any particular vegetational regeneration, probably because of the continuation of an agrarian economy. Boreholes made in the delta of the old Rhône and the current Rhône off the Golfe du lion by N. Acherki (Acherki 1997) also show, at 
Article published in BARCELÓ M. et SIGAUT F., (eds.), The Making of Feudal Agricultures ?, Boston-Leiden, Brill editor, coll. The transformation of the Roman World, vol. 14, 2004, p. 177-253.

the same time, an intensification in human activity with almost the same pointers to cultivation as previously. Pinus $s p$. and Buxus sempervirens, the latter indicative of an open environment, are added to the list of taxa. These sondages add to and mostly support the conclusions reached by N. Planchais in his study of the lagoon site of Marsillargues on the edge of the Etang de Mauguio (or de l'Or) in the Languedoc (Planchais 1982). N. Planchais attributed a first fall in the oak-beech curve, visible in the level of frequency of Fagus in pollen assemblages of the end of the Iron Age, to a first phase of clearance. If the Roman period is unremarkable in the pollen diagram from Marsillargues, the land charcoal spectrum of this period shows an opening up of the environment on the alluvial plains and the immediate surroundings of the sites studied poor in naturally generated forest: forest management, evidenced by coppiced wood, plays an important role (Chabal 1997, 132). A similar situation is shown further West in the lower valley of the Aude in the sequences of Peyrac and Capestang (Guilaine et alii, 1990) and comparable to the result obtained at Marsillargues and in the Golfe du Lion. They record the same double evolution: a marked decrease in the deciduous oak forest and /or of the oak-beech woods in favour of Quercus ilex-coccifera, or Pinus, notably at Peyrac, and in favour of open garrigues or moorland (heathers, cypresses, Buxus) conjoined with an increase in indicators of human activity (Cerealia, Plantago, Artemisia, Juglans, Olea, Vitis).

In the hinterland of the Languedoc, in the coomb of l'Hortus, J.-L. Vernet has followed the establishment of the green-oak cover at the expense of deciduous oak at some time between the end of the $4^{\text {th }} \mathrm{C}$ and the $5^{\text {th }} \mathrm{c}$ (Vernet 1973). The palynologist J. Renault-Miskovsky notes that on that site the tree pollen component falls from $22.5 \%$ to $7 \%$ while Carducaea, Anthemidia and chicory plants are on the increase. An examination of the texture of Quercus pubescens reveals that wood from hearths is gathered first from tightly forested stands and then later from more and more open areas. The activity of smelters requiring wood for their hearths in the vicinity is in this case directly responsible for the transformation of the landscape, not for agriculture but for the management of wood resources. This opposition must, however, not be exaggerated

Since we are dealing with a homogeneous milieu, regional differences can nevertheless be apprehended. In the basin of the Aude, the decrease in mesophilic species is more pronounced and earlier, and, in general, the beginning of woodland clearances takes place more quickly than at Marsillargues, where Cupressacea and Ericacea, indicating open environments, only reach their peak after the early Middle Ages. Thus, to the East of the Hérault, the end of the protohistoric era and the beginning of the Roman period are marked by a fall in tree pollen, indicating extensive forest clearance. This state of affairs is to be linked to the proximity of Narbonne, capital of the Roman province, and to a greater degree of regional urbanisation than on the coast of the eastern Languedoc, where the principal Roman centres are located in the interior (Nîmes). The effects of the 6th-7th C crisis are also felt differentially: in the boreholes studied by N. Acherki, the strong presence of weeds betrays an intensification of farming activity from the $7^{\text {th }}$ and $8^{\text {th }} \mathrm{C}$ (Acherki 1997); on the Marsillargues pollen diagram, around the $8^{\text {th }} \mathrm{C}\left(1300^{-}\right.$ $60 \mathrm{BP})$, human intervention upon the forest environment is perceived through the rapid decrease in Quercus pollen of ilex type (including $Q$. ilex and $Q$. coccifera); it denotes an episode of woodland clearance for cultivation. This event is indeed accompanied by the appearance in continuous pollen curves of cultivated taxa: Castanea sp., Juglans sp., Olea $s p$., Vitis sp. Coincidentally peaks in Ericacea, Cerealia and a whole series of introduced weeds all point in the same direction. At Psalmodi $\left(5^{\text {th }}-12^{\text {th }} \mathrm{C}\right)$, Mauguio $\left(11^{\text {th }} \mathrm{C}\right)$, and Lunel-Vieil $(10$ th-12th $\mathrm{C})$, at east of the Rhône delta, the landscape is cleared of woodland. Mixed oak forest is receding and Aleppo pine plays a major role (Durand 1998, 329-332). Indeed this species behaves like a veritable stop-gap, re-colonising open areas faster than green oak. At Lunel-Vieil, however, there is evidence for the regeneration of oak woodland at the turn between the $4^{\text {th }}$ and $5^{\text {th }} \mathrm{C}$ (Raynaud et alii 1990, 318-326).

All the signals given by the charcoal evidence indicate a strong anthropisation of the milieu from the beginning of the early Middle Ages. On the plain of eastern Languedoc in particular, many intensive and diversified developments, notably the establishment of orchards, have been recognised. Written documents support these findings: the flourishing of benedictine monasteries, of which Psalmodi is a prime example, encouraged by royal and later imperial politics, as well as the establishment of refugee settlers from Spain under a specific contract, the aprisio, explain that Carolingian forest clearances resulted in both an agrarian colonisation and an intensification of land ownership. Regional differences exist nevertheless. In the Massif Central, J.-L. De Beaulieu, A. Pons and M. Reille have carried out pollen analyses of 88 peat, lake or bog sites, for which $160 \mathrm{C}^{14}$ dates were available. This analysis demonstrates that the Gallo-Roman period saw widespread forest clearance which is ascribed to an exploitation of the environment similar to that observable in the $19^{\text {th }} \mathrm{C}$. The re-afforestation that followed began during the $4^{\text {th }} \mathrm{C}$ and lasted into the middle of the $9^{\text {th }} \mathrm{C}$ (Beaulieu et al. 1988). 
Article published in BARCELÓ M. et SIGAUT F., (eds.), The Making of Feudal Agricultures ?, Boston-Leiden, Brill editor, coll. The transformation of the Roman World, vol. 14, 2004, p. 177-253.

\section{2. - The question of burning}

Land clearance is associated with fire, whose place in agriculture is much debated: for a long time this question was tackled by historians as well as botanists and plant geographers only to deplore the erosion, desertification and devastation that ensues. But up to the $19^{\text {th }} \mathrm{C}$, when mechanisation became available, land clearance by fire of moorland, grassland or forests was the only known and used technique to extend the surface of arable land. In the central Pyrenees, detailed studies by J.-P. Métailié on pastoral fire (Métailié 1981) have given back to fire its role as a natural agent in the working of many ecosystems. Yet this role is difficult to characterise in written documents: mentions of the use of fire or ash by ancient agronomists are rare and restricted to stubble or brushwood burning or to the use of ash as fertiliser (Sigaut 1975, 295). Medieval Carolingian sources are completely silent on the subject. Therefore, archaeology is called in to play and develop procedures to apprehend these practices, as has been achieved in Northern Europe, where pollen analysis of peat bogs makes it possible to date the beginnings of agriculture thanks to burning practices.

Detailed observations on sediments in the Valdaine and later in the plain of Orange have led J.-F. Berger to question the origin of the fires attested by charcoal which appears on thin section slides prepared for micromorphological analysis. In the Valdaine, a series of fires is to be linked to burning practices within a pastoral economy. According to Berger, the exploitation of the massifs from the $4^{\text {th }}$ to the $10^{\text {th }} \mathrm{C}$ would have been «marked by periodic fires and the upkeep of open spaces, where Fruticea plants and dry grassland predominate according to the snail population identified in alluvium at the foot of slopes. The spectra of the burnt vegetation are typified by the absence of oak (Q. pubescens) and the frequency of elm, ash, box trees and Rosaceae (Sorbus type), evoking an open forest-edge or hedge environment in the hills and peripheral plateaux» (Berger 1995, 105). Lower down, in the plain of Orange now bisected by the TGV, further observations could be made on the dual sites of Caderousse-lesCrémades and les-Négades. Sediments recorded «burning of hedges or forest-edges», most probably associated with cereal cultivation, whose last phase is dated to the course of the $6^{\text {th }} \mathrm{C}$. In the following two or three centuries, «traces of human activity are only perceptible in the form of fires of the deciduous oak forest» which is thought to be linked to husbandry (Berger forthcoming).

These observations are made in the framework of a reflexion on « the role fire in the techniques used for preparing fields in ancient European agriculture» pursued by F. Sigaut in his book L'agriculture et le feu (Sigaut 1975). He has shown that slash and burn clearance, soil enrichment, manuring, burning of fallow land, moorland and pastures with running fires are specific agrarian techniques. Those who are seeking their traces in the ground agree on the difficulty in identifying such horizons and in distinguishing them from natural fires or fires started without pastoral or agrarian objectives ( Boissinot and Brochier 1997, 42-44). Taking into account a climatic phase typified by a degree of drought at least during the $9^{\text {th }}$ C, J.-F. Berger and S. Thiébault suggest that a natural propensity to fires could have been combined with a period of reorganisation of the agrarian system requiring new land for pastures to be gained (Berger an Thiébault 1997). This suggestion is the supported by further palaeoecological data. In the Valdaine (the region of Montélimar), the period is characterised by the growth of «evolved meadow soils», favouring the development of a pastoral economy. Land snail analysis shows that in marl zones marshy ecosystems and water meadows superceded cultivated fields (Berger 1995, 103). But confirmation through archaeological data or written sources is needed to validate such a thesis.

Indirect evidence may confirm that land has been cleared by fire. One of the more secure hypotheses is the relationship between burning and certain crops. This is the case of root crops and green crops (Sigaut 1975,115), and, amongst grasses, buckwheat (Fagopyrum), identified for the Middle Ages at Canet-Saint-Nazaire by N. Planchais (Planchais 1985). It is also the case of some ligneous plants. In the Pyrenean part of the department of the Aude, at Pinet, pollen assemblages from a peat bog located at an altitude of $880 \mathrm{~m}$ are marked by a drop of the oak and beech-fir (Fagus, Abies) count and by a temporary peak in the frequency of Betula. Birch trees, together with alder are pioneer species which recolonise burnt coniferous forests, because germination of the seeds of the former species are stimulated by ashy soils (Sigaut 1975, 112). At Pinet, pollen-analytical indicators, considered as characterising changes due to the introduction of husbandry (Poaceae, Plantago lanceolata, Chenopodiaceae) support the interpretation that the site is a clearance site: land has been gained from the forest to be turned into pasture. At the same time, the increase in the frequency of cultivated plants (Cerealia, Fagopyrum) and weeds (Artemisia and other Compositae) testifies to the establishment of fields (Reille 1991). Furthermore burning entails a mineralisation of organic matter which acts as fertiliser and benefits plant growth. F. Sigaut reminds us that «in experimental clearance trials, Danish archaeologists witnessed the appearance of a characteristic plant population 
Article published in BARCELÓ M. et SIGAUT F., (eds.), The Making of Feudal Agricultures ?, Boston-Leiden, Brill editor, coll. The transformation of the Roman World, vol. 14, 2004, p. 177-253.

consisting of lanceolate plantain, various composites (dandelion, daisies, thistles) and some species of moss. This situation had also been observed in clearances in the New World, where «plantain was, to the Indian, the trail of the white man» (Sigaut 1975, 112-113). The results from pollen analysis of the site of Marsillargues also suggest an interpretation along those lines. The pollen sample records the increase of Cupressacea, in particular juniper from the Early Middle Ages. Junipers are, just like birch, pre-forest bushes establishing themselves on formerly cultivated soils and which lead to the reconstitution of a forest cover and forest soil. In the hinterland and coastal landscapes, a syncopated triennial rotation system of winter cereals and oats has been identified (Durand 1998, 312-323). By «syncopated», it is understood that cultivation systems existed within an internal organisation of the landscape without being complete, unlike full rotation systems (R.Fossier). Such a system with long fallow periods an only work as an itinerant system on temporarily cleared land. The increase in junipers at Marsillargues in the Early Middle Ages has also been interpreted as direct evidence for an itinerant cereal culture on burnt land.

Such still dispersed results need further evidence. Nevertheless they already show that the slash and burn system that had rendered the expansion of societies from the Neolithic onwards possible had not been abandoned during the $5^{\text {th }}-12^{\text {th }} \mathrm{C}$. In general histories of agriculture, the Middle Ages are considered to be the period in which heavy ploughing with drought animals is introduced; in lowland zones, this system replaces a system with fallow periods and husbandry, associated with light ploughing with drought animals which existed since at least the early Roman period (Mazoyer and Roudart 1997, 128). In spatial terms, a general tendency observable at the level of a huge geographical zone does not prejudice the reality of customs that can be apprehended at a micro-regional and even regional level. Indeed, not all landscapes lend themselves to such an evolution and research emphasises the attachment of peasant communities to tried and trusted methods and techniques.

\section{AGRICULTURAL PRODUCTIONS}

Comparing archaeological and palaeoecological studies makes it possible to tackle the question of agricultural production in a period where written documents remain rare.

\section{1. - Oil production}

Roman oil production has been the subject of much attention in the 1980s and was considered to be the major agricultural activity of the province. Cultural reasons dictated such a position: the olive is the plant most closely linked with Mediterranean civilisations. Certainly in modern times it was the case that olives played this major role in Provence. Results from archaeological surveys supported this position, while excavations of production sites allowed the technical characterisation of pressing systems to be undertaken and to evaluate the size of these production sites (Brun 1986). Furthermore, pollen specialists favoured this interpretation. For them, it was expedient to establish a relationship between the increase in the percentage - the «peak»- of Olea observed in pollen diagrams and the Roman period. As a result, a circular argument developed: pollen analysis was validating a theory borrowed from historians, that is to say the massive increase of oil production in southern Gaul. But, unlike what was happening for wine production, it has not been possible to pinpoint the existence of an amphora production specific for oil: there was no such thing as an oil amphora from the Narbonnaise, whose distribution could be mapped. On the contrary ceramic studies emphasised the importance of imports from Spain and Africa. A comparison between production sites in the Narbonnaise and production sites in Africa where large scale buildings are much more frequent was already pointing in this direction.

Facts had to be faced: the relative ease with which oil production could be identified in surveys was at the origin of the overestimated situation. Olive pressing indeed produces characteristic stone equipments: large blocks of stone, easily identifiable in surveys, are used as counterweights and for other parts of the presses. The economic importance of oil production in Provence during the Roman period has been re-evaluated since 1990. In pollen diagrams, signs for cultivated Olea are recorded from the end of the Subatlantic without precise dates. This is the 
Article published in BARCELÓ M. et SIGAUT F., (eds.), The Making of Feudal Agricultures ?, Boston-Leiden, Brill editor, coll. The transformation of the Roman World, vol. 14, 2004, p. 177-253.

case of the pollen sequences of Ponts-Clapets-Fos and Grands-Paluds-de-Fos D20 (Triat-Laval 1978) and of l'Etangdu-Pourra (Laval et al. 1991) on the eastern side of the Rhône delta. The cultivation of olive trees is dated in only one diagram, that of the Etang-de-Berre (Laval et al. 1991), where its beginning is dated to $1070 \pm 70 \mathrm{BP}$. In the Vallée-de-Baux, evidence for post-Roman periods has been greatly damaged by deep ploughing for rice cultivation. By contrast, on the eastern edge of the plain of Arles at La Calade (Fontvieille), V. Andrieu has been able to observe in a sequence starting in the $11^{\text {th }} \mathrm{C}$ a very steep rise in the pollen of Olea, reaching a maximum of $6 \%$ of the pollen population and testifying for a regional oil production. Olive trees were not absent previously, but the pollen count remains low, although the possibility that olives were cultivated cannot be excluded (Andrieu-Ponel et al. a 2000, 353). All in all, the zenith of oil production in Southern France is medieval and modern: it is linked to trade with Northern Europe.

In the pollen samples of Marsillargues, of the Golfe du Lion and of the basin of the Aude (Planchais 1982, Acherki 1997, Guilaine et al 1990), olive is recorded as present since the beginning of the pollen sequences, but in a sporadic and fleeting manner. The major cultivation peaks date to the Early Middle Ages, around the $8^{\text {th }}-9^{\text {th }} \mathrm{C}$, since they post-date the $\mathrm{C}^{14}$ date of $1300 \mathrm{BP}$ in the eastern lagoons. Charcoal analyses of the sites of Augery $\left(9^{\text {th }}-10^{\text {th }} \mathrm{C}\right)$, Psalmodi $\left(5^{\text {th }}-12^{\text {th }} \mathrm{C}\right)$ and Mauguio $\left(10^{\text {th }}-11^{\text {th }} \mathrm{C}\right)$ endorse these findings, depicting an alluvial plain where fruit culture, with olives in the first place, occupies an extensive surface. At present, work on fruit remains has not yet confirmed these findings, but this is due to the rarity of studies dedicated to the Carolingian period in Mediterranean France (Ruas 1992, 1993). Historic documents of the region do not record an increase in oil production during the $8^{\text {th }}$ - $11^{\text {th }} \mathrm{C}$ either, even though olive groves are not unknown. By contrast, the documents show a phase of intensification in farming when fruit trees are planted in the Languedoc landscape from the $11^{\text {th }} \mathrm{C}$ onwards: olive groves invade the plateaux, garrigues and sedimentary basins such as the Vaunage. At the beginning of the $12^{\text {th }} \mathrm{C}$, olive production is sufficiently advanced to become a specialist affair: the existence of specialist workers, the olivadors, and a special duty, the olivigarium, suggests an advanced level of technical know-how in olive oil production methods (Durand 1998, 345). In Provence, at least in the region of Arles and in the hinterland of Nice, olive cultivation on a large scale will have to wait until the beginning of the $15^{\text {th }} \mathrm{C}$ (Boyer 1991, 147, Stouff 1988).

The increase in surveys has also confirmed that the extent of archaeological remains concerning ancient olive oil production had indeed been overestimated. Oil production is well attested in the Languedoc (Garcia 1992) and never absent anywhere. But it has left traces mainly on the coast of Provence in the department of the Var and in the Marseille region (Leveau et al. 1991). In summary, the data gathered confirm Strabo's report that olive trees were introduced into Southern Gaul via Marseille. The mild winters of coastal Provence explain why remains of olive oil production are more frequent there. Cultivated species of higher yield, introduced by the Greeks of Marseille, probably found better conditions in the department of the Var than in the lower Rhône area and the Languedoc, areas which can suffer from hard cold spells. The diffusion of olives towards the north and the west would have been constrained by the climate. Indigenous species were adapted to harsher conditions, but their Yield would have been lesser. The historic dimension in this discussion is of fundamental importance. The most likely explanation for the fact that the greatest increase in olive cultivation actually happened during the Little Ice Age must be in the care given to the trees. Economic reasons must have discouraged Roman agronomists from applying to olive production the know-how that they had proven in the care of vineyards. But it cannot be excluded that certain aspects of the Mediterranean climate which were beneficial to the growth of cultivated olive trees only appeared in the region during the Middle Ages (Jalut et al. 1997).

\section{2. - Wine production}

Up to recent years, wine production was known in Gaul through a few written sources that were used by R. Dion to trace the origin of viticulture in a celebrated book (Dion 1959). Archaeological data have completely revolutionised the subject since the 1980s. First, the study of amphorae, in particular that of F. Laubenheimer, established that wine was exported in specific amphorae, the so-called «Gaulish» amphorae. The mapping of amphora kilns has thus made it possible to draw the first maps of the extent of the vineyard in Southern Gaul (Laubenheimer 1992). Its produce was exported northwards towards the borders of Germania and the British Isles. Imports of Gaulish wine are of great importance in Rome up to the $3^{\text {rd }} \mathrm{C}$. And in the East, it is exported as far as India. New advances in archaeological research have been made in the 1990s. On archaeological sites in the Rhône valley, in the Languedoc and in Provence, excavations have revealed production and storage sites. These 
Article published in BARCELÓ M. et SIGAUT F., (eds.), The Making of Feudal Agricultures ?, Boston-Leiden, Brill editor, coll. The transformation of the Roman World, vol. 14, 2004, p. 177-253.

establishments come in all shapes and sizes. The most important cellars known up to now are those of the Mollard at Donzère in the Rhône valley in the department of the Drôme and Rians on the northern side ot the Montagne SainteVictoire in the department of the Var where the maximum storage capacities are estimated to be in the order of 2500 hl for 200 dolia (Odiot 1996) and $1760 \mathrm{hl}$ for 176 dolia (Brun 1999, 599-600) respectively. The discovery of vineyard plantations represents the third and latest phase in research. Taking into account the conditions that favour the preservation of vineyards in the plain or on lower slopes rather than on hillsides, soil stripping that was occasioned by road or rail (TGV) constructions has brought to light vast surfaces planted with vines (Boissinot 1997) and has caused a new specialism to be born, that of the archaeology of fields (Monteil et al. 1999). Archaeobotanical studies have sprung from this work, just as for olives and along similar lines; in particular, they allow us to question afresh the botanical basis for the emergence and the growth of viticulture in Gaul. A secure basis would enable us to vindicate or to refine the role Marseille in relation to the indigenous population (Marinval 1997). On archaeological sites, the study of fruit, charcoal and wood remains makes it possible to identify the presence of vines. The pollen of Vitis does not get dispersed as widely as that of the olive tree. In the landscape, however, the pollen signature of vines is a constant element of all pollen diagrams: at Embouchac near Lattes, for example, it is one of the typical taxa of the Subatlantic (Puertas 1998 and 2000): percentages up to $16 \%$ leave no doubt that this is the cultivated variety and not a wild vine $(<2 \%)$.

Based on the study of cellars, it used to be thought that wine production saw a slow decline from the $3^{\text {rd }} \mathrm{C}$ onwards. But the most recent studies come to refine this view. The association between viticulture and storage space in dolia, a well established feature of Southern Gaul, is not known further North in Northern Gaul, for example in the vineyards of the Mosel. Storage in barrels, whose archaeological identification is extremely difficult, must therefore not be excluded. This is what J.-P. Brun proposes for Provence (Brun 1993) and C. Pellecuer for the Languedoc. The latter scholar has established that wine continued to be produced in the Languedoc in the $5^{\text {th }} \mathrm{C}$. It is present already in a villa close to the oppidum of Ensérune, at Nissan-lez-Ensérune/Les Fargettes next to Béziers (Pellecuer 1996). But his major work is concerned with the villa of Près Bas at Loupian on the edge of the Etang de Thau (Pellecuer, forthcoming). Presses are installed again on this villa site in the second half of the $4^{\text {th }} \mathrm{C}$, when a storage building is also constructed. Later, at the beginning of the $5^{\text {th }} \mathrm{C}$ the residential wing of the villa is rebuilt and extended at the expense of the storage buildings. But wine growing does not disappear. A wine production site has been identified at Bourdou/Port de Loupian, only $2 \mathrm{~km}$ from the villa. This new site represent at present the latest known architectural evidence for local wine growing. Palaeoecology and the archaeology of fields contribute further findings in the same vein. Wine growing also seems to be documented for the phase 370/425 around the farm site excavated at Les Jurières-Basses at Puissalicon $10 \mathrm{~km}$ from Beziers in the department of Hérault. There, on the other hand, in the phase dated to the second half of the $5^{\text {th }} \mathrm{C}$ and early $6^{\text {th }} \mathrm{C}$, Vitis has practically disappeared from the charcoal samples (Mauné et al. 1998, 108). The data from the archaeological excavation of fields at Dassargues give similar indications. Trenches have been identified as traces of the planting of a vineyard of several hectares dated to the $5^{\text {th }}$ and $6^{\text {th }} \mathrm{C}$.

Archaeological records are silent for the ensuing period. This silence and the lack of texts would suggest a decline in wine growing in Provence as a well as in the Languedoc. Indeed, testimonies for the existence of vineyards or vine plantations reappear only in the 9th-10th C, with the first scraps of written documents. First in the urban zone: in the ancient Roman cities, a hanging vine nearly always gives shade to the domus or the domus cum curte. In the countryside, vineyards are recorded alongside fields in the long lists of goods in villa inventories. However, even though wine culture is well and truly present, it is hard to fathom its size in the $9^{\text {th }} \mathrm{C}$; but in the $10^{\text {th }} \mathrm{C}$, the growth of viticulture, in particular in the Biterrois, preludes the great growth of the Middle Ages proper, from 930-960 AD (Bourin-Derruau 1987). Indeed, by means of the plantation contract, part of the land devoted to growing cereals becomes a vineyard. The extent of wine growing is also shown by the existence of «maieuls» and young vines which indicate that the land was freshly put to this use. M. Bourin is convinced by the strength of such a phenomenon, when considering the relationship between the number of occurrences of new vineyards and the total number of vineyards cited in documents. The mobility of land devoted to wine growing, a sign of the vitality of the market, is a further indicator. This increase does not take place on newly cleared land, but on old land in the plain. Vineyards are established in lowland zones, near streams and rivers, on good, humid alluvial land. For a rural farmstead, a manse, two to three vineyards are recorded for 5 to 6 fields (Bourin-Derruau 1987). In the Nîmes chartulary of the $10^{\text {th }} \mathrm{C}$, vineyards form large surfaces of conjoined land. Such popularity, in particular in urban zones, cannot be explained purely by an increase in consumption. M. Bourin considers the possibility that some of the production was exported, but without any supporting evidence. Archaeology is of little help since wine is sold in barrels and no longer in 
Article published in BARCELÓ M. et SIGAUT F., (eds.), The Making of Feudal Agricultures ?, Boston-Leiden, Brill editor, coll. The transformation of the Roman World, vol. 14, 2004, p. 177-253.

amphorae. Nevertheless, Vitis $s p$. is recorded in small percentages in charcoal analyses at Psalmodi $\left(8^{\text {th }}-12^{\text {th }} \mathrm{C}\right)$, Lunel-Vieil $\left(10^{\text {th }}-12^{\text {th }} \mathrm{C}\right)$ on the western side of the Rhône delta and Béziers $\left(13^{\text {th }} \mathrm{C}\right)$, whereas this taxon is absent from Augery on the northern Camargue $\left(9^{\text {th }}-10^{\text {th }} \mathrm{C}\right)$. Whatever the reason, the growth of the vineyard of the Languedoc around 950 represents a new form of investment, often of speculative nature since it gives good returns. It results in an increase in commercial relations. This expansion continues through the following centuries. Th. Sclafert insists on the importance of vineyards in the valley of the Durance (Sclafert 1959). And vines are cultivated in the Valdaine at the east to Montélimar according to charcoal analysis.

\section{3. - Cereal production}

Identifying cereal cultivation poses a complex problem for archaeologists, similar to that posed by husbandry. Both activities are identified on rural sites by remains linked to the consumption of their end-products: food refuse, stone artefacts used for grinding flour. But cereal consumption is at the basis of nutrition; therefore the number of mortars or millstones found on a given site does not permit local production to be estimated. More than for oil and wine, it is necessary to distinguish between two types of production. In the case of a subsistence economy, grain production provides for local consumption. It allows, in second place, to extract surpluses for export. Such a type of production existed in Southern Gaul in the Roman period. At the end of the $2^{\text {nd }} \mathrm{C} \mathrm{BC}$, Marius had to import wheat to feed his troops, stationed in the Rhône valley. In the years around $75 \mathrm{BC}$, Fonteius has to resort to confiscations in order to supply the armies of Pompey in Spain. The situation changed during the Roman Empire and the province of Narbonnaise became an exporter. A painted inscription on a small amphora records this new situation, telling us that in the $1^{\text {st }} \mathrm{C} \mathrm{AD}$, the Cavares were sending barley from the region of Avignon to Marseille (Liou and Morel 1977). Alongside the open market, there was a state-controlled market whose purpose it was to participate in the supply of Rome: two texts are probably to be put in relation with the concept of the annona (C.I.L., III 14185 and C.I.L., XII 672 = I.L.S. 1432). Archaeological sources are not explicit. It is much harder to extract information out of cereal fields than out of orchards, whose excavation can pinpoint the spacing of trees or bushes. As for storage, difficulties are just as great. Storage in the Roman period is above ground and therefore granaries are difficult to identify. In the protohistoric period and in the Middle Ages storage takes place underground. But even in this case, problems abound. Though the excavation of storage pits provides information on the volume of stored grain, it is however much more delicate to interpret the food remains that they contain in terms of actual consumption, as it is exceptional to encounter an intact storage pit: these features, having been emptied of their primary content, were often used for rubbish disposal (Raynaud et alii 1990).

The recent development of environmental approaches for the period under study throws new light on this question. The work undertaken in the lower valley and delta of the Rhône is a good illustration. As F. Benoit wrote, the Camargue was probably not a granary, fishing activity and other activities linked with the sea being important (Benoit 1959; 1965, 116, n. 33). But whatever their importance, cereal agriculture played a fundamental role during the Iron Age and the Roman period, never really disappearing. In these sectors, the production of cereals would have thus known a widespread extension onto alluvial soil after drainage. It would have been one of the reasons for the prosperity of the Roman colonia of Arles. A few pollen analyses give support to the hypothesis that land was dedicated to wheat a little further north in the region. Cereal cultivation appears indeed distinctly in the profiles drawn by H. Triat-Laval in his thesis. Though no precise date could be given to the profile from Barbegal, the profile of La Calade, a few kilometres further on and on the edge of the Rhône plain shows a continuous curve for Cerealia in the later Iron Age and the Roman period: Ceralia $s p$. dominates but rye is present and introduced weeds (Centaurea solstitialis and Polygonum aviculare) are occasionally recorded. For V. Andrieu-Ponel it constitutes proof that cereals were grown in the plain of Arles. Later, in the second phase corresponding to the Merovingian and Carolingian periods, the curve becomes more continuous, reaches 3 to $4 \%$ of the total and the presence of Centaurea also becomes continuous. A third phase, whose beginnings are dated around $1200 \mathrm{AD}$ and corresponds to the Middle Ages proper is characterised by a high level of cultivated plants or weeds in a continuous curve, reaching as much as $8 \%$, with Centaurea solstitialis present in very high proportions (Andrieu-Ponel et al. 2000, 353). At Augery-deCorrège in Tête-de-Camargue, around the period of the $9^{\text {th }}$ to early $11^{\text {th }} \mathrm{C}$, the analysis of pollen spores reveals a regular increase in cereals (Laval and Malléa, 1993). For the western plain of the lower Rhône, boreholes carried out in lagoon sediments (Marsillargues, Golfe du Lion) (Planchais 1982; Acherki 1997) give a similar general image of an increase of cereal cultivation during the historic period. But there, just as in the Camargue, the major peaks in 
Article published in BARCELÓ M. et SIGAUT F., (eds.), The Making of Feudal Agricultures ?, Boston-Leiden, Brill editor, coll. The transformation of the Roman World, vol. 14, 2004, p. 177-253.

Cerealia are not recorded during the Roman period, nor do they occur during the period of late-Roman to early Medieval transition, but during the Carolingian period.

In syntheses on produce at the level of France, the singular position of Southern France in the Carolingian period has been pointed out a number of times (Ruas and Marinval 1991; Ruas 1999). The classical disparity between coastal plains and mountains reflected by a much clearer diversity of cereals in hilly regions belongs to the sum of new scientific knowledge acquired in the last few years. It is notably shown by the dominant place occupied in mountains by so-called secondary cereals, in particular the two types of millet, common Millet and Italian Millet, two hulled cereals which medieval documents of the Languedoc do not mention (Ruas 1999) and in the plains by oats and emmer wheat. According to the overview tables, it seems that the diversity in cereals that typifies the South and the hinterland-coast dichotomy was born during the period spanning the $5^{\text {th }}-10^{\text {th }} \mathrm{C}$. But for the time being, the lack of data in sequences does not allow us to be entirely positive about the period of transition between the late Roman and early Middle Ages, whereas for the Iron Age and the beginnings of romanisation we are better informed. Pollen analysis also records the progression of rye, beans and buckwheat. The latter species is only encountered in the pollen analysis of Canet next to Perpignan in the Roussillon (Planchais 1985) and of Pinet in the Pyrenean part of the department of the Aude (Reille 1991) around the $13^{\text {th }}$ C. Originating in central Asia and perhaps cultivated on the Armorican peninsula from the Iron Age onwards, it only spread late in the Mediterranean zone. These puzzling indications seem to give weight to the hypothesis that this plant was cultivated well before its first mention in written documents $\left(15^{\text {th }} \mathrm{C}\right)$. Often linked with autumn-germinating weeds, the Mediterranean cereals were generally sown at the end of the summer and regularly hoed; this suggests that sowing was done in rows and not broadcast, which goes against the accepted historical tradition (Ruas 1999).

\section{4. - Fruit production}

Oil and wine are well and truly the principal products of fruit-bearing agriculture of the $5^{\text {th }}$ to $11^{\text {th }} \mathrm{C}$. But vines and olive trees are not the only trees cultivated for their fruits. By demonstrating that Mediterranean farming is not reduced to the intensive cultivation of the classical Mediterranean wine-olive-cereal trilogy,archaeobotanical data has struck a blow to the stereotype of a Mediterranean landscape and enriched its image.

In Southern France, archaeobotanical research tends to confirm what was already hinted at by written sources. An example is the analysis of fruit remain assemblages from the site of Coudouneu, on the northern side of the Étang de Berre, excavated by F. Verdin: the plant remain study by Ph. Marinval has highlighted the presence of garlic, a plant that is only recorded in the $1^{\text {st }} \mathrm{C} \mathrm{AD}$ in Italy (Marinval 2000). The beginnings of a fruit tree culture are visible from the Iron Age and are to be linked with the increase of exchanges between indigenous peoples and seafaring peoples who transmit the knowledge from the East, Italy and Africa. These beginnings are earlier than further north and they reveal a real sophistication in growing techniques inherited from the classical and hellenistic Greek world, where horticulture and fruit tree culture were common practice (Ruas 1996). This chronology confirms that the economic penetration of these regions by Marseille and later by Rome took place earlier than the conquest and the administrative reorganisation of Southern Gaul. An eloquent example is given by the walnut tree. Since H.-J. Beug published his article (Beug 1975), pollen specialists interpret the presence of Juglans not only as an indicator of human activity, but also as a convenient yard-stick for measuring the increasing part played by agriculture. Around $2270 \mathrm{BP}$, or the $3^{\text {rd }} \mathrm{C} \mathrm{BC}$, the Juglans-line showing the extent of the introduction of walnuts circumscribes the northwestern Mediterranean.. In broader terms, the spread of this tree is linked with «romanisation» and its presence is used as a dating element at Pinet as well as at Marsillargues. It is thought that walnut trees were still in an expanding phase in Italy in the $1^{\text {st }} \mathrm{C}$ AD and that its spread was far from completed (Benzi and Berliocchi 1999, 90). Meanwhile, the latest archaeobotanical analyses appear to date its appearance back to around $3500 \mathrm{BP}$ (Triat-Laval 1979; Arnaud-Fasetta G. et alii, in preparation). The study of ancient seeds in particular shows that walnuts spread in Gaul earlier than previously thought. In northern France, Juglans regia is recorded in the late Neolithic or Copper Age (Ruas and Marinval 1990, 420), and in southern France in the Aveyron (Krauss-Marguet 1981). It is cultivated in the Valdaine, according to charcoal analysis. In fact, there are old records in historical documents, an unsurprising fact since walnuts are linked to religious traditions. The Greeks associated walnuts with the cult of Dionysos and the Romans with that of Jupiter, as indicated by its name: Jovi glans has given Juglans.

Archaeobotanical work has led to a reconsideration of the influence of the oriental world. Since the famous remark by J. Le Goff, it is accepted that apricot trees are really the only benefit brought back from the Crusades in 
Article published in BARCELÓ M. et SIGAUT F., (eds.), The Making of Feudal Agricultures ?, Boston-Leiden, Brill editor, coll. The transformation of the Roman World, vol. 14, 2004, p. 177-253.

the north-eastern Mediterranean. By all accounts, it seems that Prunus armeniaca had already been cultivated well be fore the $11^{\text {th }} \mathrm{C}$ in the Languedoc. Charcoal analysis undertaken by L. Chabal at the Moulin Villard and at Lunel-Vieil in the plain of the Vistre at east of the Rhône delta identifies this tree in the $1^{\text {st }} \mathrm{C} \mathrm{AD} \mathrm{(Chabal} \mathrm{1997,} 113$ and 130). A single kernel found on the oppidum of Nages in Vaunage reveals that apricot was consumed in the second half of the $2^{\text {nd }} \mathrm{C}$ (Pottrain and Py 1975). Almond trees are thought to have been introduced by the Greeks into protohistoric Gaul; at least this is L. Chabal's hypothesis, to explain the presence of almonds on the island of Porquerolles in the offing of Toulon (Chabal 1991). Note that during the Carolingian period, almond trees are the object of special care: the size of vessels (wood cells) from charcoal samples of Psalmodi show that irrigation took place. As for peach trees, analysis of fruit remains as well as charcoal analysis shows that it was present in the region well before the Middle Ages.

Sites of the $5^{\text {th }}$ to $11^{\text {th }} \mathrm{C}$ in the southern zone reflect a well established fruit growing economy. Already in 1982, when interpreting the pollen data from Marsillargues, N. Planchais defined the Early Middle Ages as « a period of very intensive and very diversified development fundamentally different from the current agricultural and wine producing organisation», where orchards of Rosaceae occupy a choice place. Further charcoal analyses come to confirm and to broaden this vision. From the end of the $8^{\text {th }} \mathrm{C}$, oak and pine woods leave space for fruit tree cultivation which is entering a major phase of expansion: cherries, almonds, figs, olives are grown over the whole of the lowland plain of the eastern Languedoc. Charters of the Languedoc hinterland in the Middle Ages proper reveals that fruit cultivation is sufficiently spread to have become a specialist affair: the cellarium -keeper of the abbey of Aniane (Herault), responsible for its supplies, - must feed the olivadors and the amanliadors every day (cart.An. n $^{\circ} 100$ p.240(1181-1188). Such a terminology implies certainly that there was a technical expertise linked to a differentiation of tasks depending on species. The existence, if not of a group of specialist workers, but at least of a workforce attached to a specific type of fruit culture, speaks for advanced cultural behaviour. Written historical documents show that fruit trees were not planted only as homogeneous orchards. In the $12^{\text {th }} \mathrm{C}$ vineyards planted together with, most often, olive and almond trees occupy an increasingly important place and, except in the Biterrois, break up the uniformity of the cultivated landscape. In this respect, there is everything to expect from an improvement in southern France of an archaeology of fields which has already proved so useful in northern France, following the stripping of vast surfaces in the context of rescue archaeology. The work of Laurent Vidal has made the first contribution to this subject for the landscape of the Biterrois in the late $9^{\text {th }}$ and early $10^{\text {th }} \mathrm{C}$ (Vidal 2000, 238246).

\section{5. - Husbandry}

The study of the fauna from food refuse contained within archaeological contexts was still in its infancy some twenty years ago but is now the object of much attention from archaeologists. As a result, archaeozoology has conquered an important place in historic, ancient and medieval periods. It is now in a position to set a specific research agenda, appreciably different from that elaborated for earlier periods. In the latter, in so far as the commercialisation of animals, their meat and other products was restricted, the faunal assemblages made it possible to apprehend directly the management of flocks belonging to the community living on a given site. From the end of the protohistoric period, it may still be possible to consider a simple economic relationship between people and flocks in marginal peasant communities. But in the rural Gallo-Roman and Medieval world, the setting up of complex commercial networks prevents the establishing of a direct link between meat consumption, as apprehended through archaeozoology, and herds or flocks from the same site. Animals may have been consumed by the occupants of a given site; but they could have been marketed, so that animal bone remains constitute simply data in the study of husbandry.

\section{a.- A social indicator}

The social dimension of meat consumption is essential in faunal research. While studying animal assemblages from Roman sites along the coast of the department of the Var, M. Leguilloux observed that there were no great economic differences between the small peasants living in hamlets and the rich farmers living in mediumsized villae: a break did exist between «the latter group and that of the great landowners», inhabiting the great villae 
Article published in BARCELÓ M. et SIGAUT F., (eds.), The Making of Feudal Agricultures ?, Boston-Leiden, Brill editor, coll. The transformation of the Roman World, vol. 14, 2004, p. 177-253.

whose refuse reveals that high quality meat and venison was consumed. This situation typifies the sites of SaintMichel at La Garde near Toulon and Les Laurons at Les Arcs-sur-Argens up to the $5^{\text {th }} \mathrm{C}$ in the same region.

But the historic, Gallo-Roman and Medieval periods do not constitute a single bloc and it is important to recognise phases in meat consumption. On the site of Saint-Julien-les-Martigues at the southern end of the Etang-deBerre, luxury goods consumption is linked to the early Roman levels, whereas at the end of the Roman period a large proportion of sheep and goats is associated with a lesser consumption of beef. In this case, the analysis of the faunal assemblages joins that of the building structure: the site is first occupied by a residential villa; at the end of the Roman period and up to the $6^{\text {th }} \mathrm{C}$, the social status of its inhabitants changed: they are peasants (Columeau 1996, 132-3). In the hinterland of the Languedoc, on two sites of the early age of castles, Olargues-le-Vieux and SaintAmans-de-Teulet (Le Pouget in the middle Hérault valley), A. Gardeisen highlights the luxury consumption of suckling pork and lamb: the inhabitants of the first perched barracks of the year 1000 are not peasants, but caballarii, recorded by remains of crossbows and hunting horns found amongst bone artefacts. They are more concerned with raiding and hunting than with husbandry: their social status is a privileged one (Durand et al 1997). These examples show that a correct interpretation of animal bone assemblages requires an archaeological reflexion encompassing the whole of the site and included into a micro-regional context.

\section{b.-The question of the morphology of cattle}

Osteological studies allow the identification of an evolution in cattle populations and to define assemblages corresponding to different economic situations. For the beginning of our era, they have been incorporated into the research agenda concerning romanisation. The starting point of this reflexion comes from northern Gaul, where archaeozoologists note an increase in the size of domestic animals, particularly of cattle, for the period following the Roman conquest (Brunaux and Meniel 1983). At present, the debate is centred on the reality, the size and the interpretation of such a phenomenon. It is summarised thus by two archaeozoologists: «By extrapolation from osteometrical data, there emerges a breed of «small cattle» or Gaulish cattle associated with peat bog cattle, Bos taurus brachyceros Rütimeyer, and a breed of «large cattle» or Roman cattle, Bos taurus brachycephalus Wilckens» (Forest and Rodet-Belarbi 1998). Though in principle of a methodological and zootechnical nature, this debate is compounded by the opposition Gauls/Romans: the growth curve of the size of cattle is seen as a consequence of the Roman conquest and later of the decline of the Roman Empire. The Roman conquest would have introduced new species of greater size originating in Italy. The crisis and decline of Rome would have entailed a return to a situation prevalent in protohistoric times. This historical scheme was proposed a number of years ago but has not been endorsed by the archaeozoological research that followed. The latter have shown that the situation in Gaul was far from simple. First of all, occurrences of «large cattle» are earlier in Northern Gaul than in the South: in the former region it appeared in the last two decades of the $1^{\text {st }} \mathrm{C} \mathrm{BC}$ but in the latter region it is known only a century later (Lepetz 1997). «Large cattle» make a real impact in Southern Gaul from the end of the $1^{\text {st }} \mathrm{C} \mathrm{AD}$, that is to say two centuries after the Roman conquest. Then it remains dominant until the end of the $5^{\text {th }} \mathrm{C}$. But this predominance is not exclusive: «large cattle» does not eliminate «small cattle»; neither does the former characterise herds found in«Roman» archaeological contexts, nor does the latter typify herds from «indigenous» contexts. The data do not allow us to think that «Romans» imported breeding stock on a massive scale. It is more likely that the cattle population evolved «through a zootechnical will to obtain larger animals from an original Gaulish cattle population» (Forest and Rodet-Belarbi 1998, 1054). Rather than import herds, a rich breeder from the Narbonnaise would use the Roman slave system and settle in his "familia rustica» slave technicians able to master the techniques of breed selection; he would have bought them on the Italian or Oriental market or would have moved them from one of his other regional estates. Furthermore, it is not certain that the «large cattle» breeds are superior. Because of difficulties in preserving meat, a smaller size was not a disadvantage for meat-bearing animals if the outlets were insufficient (Columeau, pers. comm.). Larger animals were, however, more appropriate as drought animals, giving an advantage if they were destined to be used for traction on a farm or if they were to be used as beasts of burden. In fact, current osteological research does not permit to stay whether «large cattle» is remarkable for its power rather than for its weight, that is to say whether it is a traction animal or an animal bred for its meat. In any case, this phenomenon does not coincide completely with traditional chronological frameworks: it makes an impact only from the $2^{\text {nd }} \mathrm{C}$ for a period that does not extend beyond the $5^{\text {th }} \mathrm{C}$. 
Article published in BARCELÓ M. et SIGAUT F., (eds.), The Making of Feudal Agricultures ?, Boston-Leiden, Brill editor, coll. The transformation of the Roman World, vol. 14, 2004, p. 177-253.

\section{c.-A regional division of space}

Archaeozoologists are beginning to interpret the data obtained in terms of space. At the local (microregional) level in Provence during the Roman period, M. Leguilloux has made use of faunal assemblages to refine the character of an estate, that of the villa of Laurons in the valley of the Argens (Berato et al. 1990, 245). Regional specialisms have been identified. L. Jourdan had noted the importance of goat remains in the animal bone assemblages from the port of Marseille (Jourdan 1976, 133). M. Leguilloux has been able to confirm this trend in animal bone assemblages from more recent excavations: at the end of the Roman period, ovicaprids, i.e. sheep and goats together, make up between 63 and $77 \%$ of the assemblages. An extensive fleece or fur industry would have provided an outlet for the flocks of the neighbouring countryside or even from the Crau (Leguilloux 1998, 240). On his side, $\mathrm{Ph}$. Columeau recorded a great proportion of goats on the site of the Pousaraque to the South of the Etangde-Berre and suggests that these findings confirm L. Jourdan's hypothesis that goat meat was smoked or cured. These data shed light on the relationship between Marseille and its hinterland (Columeau 1996 and 1997, 29-30). In the Languedoc, A. Gardeisen and then V. Forest have shown that during the early Middle Ages, the eastern lagoon plain was specially dedicated to meat cattle breeding, a type of husbandry that is well suited to the geographic conditions of the hinterland, where husbandry is part and parcel of integrated economic and commercial networks (Gardeisen 1993, Forest 1997-1998). A relationship between the type of husbandry and a humid environment has been established by Ph. Columeau in his work on the faunal remains from the Vallée-des-Baux (Columeau 2000, 353) and from the villa of Près Bas on the edge of the Etang de Thau (Columeau, forthcoming). In a synthesis on meat consumption during the Middle Ages in the Languedoc, V. Forest insist on the diversity of the images obtained through the study of animal remains: sites in the Pyrenees stick out as sites where indigenous species were consumed, including bear and izard (Pyrenean chamois); on lowland and hilly sites cattle and sheep dominate. Thus the lowland of the Languedoc appears similar to Southern Provence, whereas sites on middle range mountains form, together with their neighbours of Northern Provence, an intermediary assemblage, between the Mediterranean coast and the region of Rhône-Alpes. Consequently an identity specific to the Languedoc, as opposed to a Provençal identity cannot be identified.

Knowledge of husbandry practices in pre- and protohistoric periods has made great progress thanks to the contribution from soil analysis of samples taken by natural historians in cave sites, where indicators contained within the sediments have shown that animals were stabled in these caves (Brochier 1991). Such methods are starting to be applied for more recent periods. But in the case of open sites, the preservation of these indicators is often poor and few attempts have been made for the historic period. Buildings dedicated to husbandry remain little-known. Caves continue to be used. The contribution of palaeoecological analyses carried out outside excavation sites is essential, in particular those of pollen analysts: the increase in proportion of nitrate-loving taxa, the Chenopodiaceae an plantain (Plantago lanceolata) is to be put in relation with the presence of flocks or herds. Such an observation was made in the sondage of La Calade on the edge of the plain of Arles, where an increase in these taxa is even used to distinguish a particular phase, phase 2: the levels are higher towards the end of the Roman period and for the Middle Ages. This interpretation has received support from a correlation with insect assemblages: the continuous presence of dungloving insects shows that along the eastern edge of the plain, a humid zone has been frequented continually by flocks (Andrieu-Ponel et alii 2000). It is therefore possible to foresee a spatial analysis that makes it possible to write the long-term history of sheep husbandry in the region of Arles. The site of La Calade is located not far from the plateau of the Crau precisely where a major discovery has recently been made, that of ancient sheep folds. Identified at the beginning of the 1990s, these buildings are now fairly well known, thanks to archaeological surveys followed by excavations. They are long, large structures pointing towards the mistral (Négreiron-Négrès 6: length: $46.3 \mathrm{~m}$; width:9.55 m; surface: $280 \mathrm{~m}^{2}$ ). Their presence is surprising; Strabo (Geography IV, 1, 7) and Pliny (Hist. Nat., 21, 57) note that flocks roamed the Crau, no doubt since a very long time ago. But that this husbandry should include sheep folds was not expected. Considering the size of these sheep folds which can shelter 700 to 900 sheep at any one time and the number of sheep folds, estimated at a around 130, a figure of 100000 sheep has been put forward. In the present climate during the dry season, such numbers could not subsist if the flocks had only access to nearby humid zones (the plain of the Rhône, the Camargue, or the edges of the Étang de Berre). This husbandry would therefore have to have resorted to transhumance, far earlier than the transhumance known in Provence at the end of the Middle Ages (Badan et al. 1995). It would go back to the Roman period. The evidence poses some problems which Ph. Columeau points out. The absence of milk teeth of lambs in the occupation levels of the sheep folds lead him to place the occupation of the sheep folds after the months of December/January . Given a better spread of 
Article published in BARCELÓ M. et SIGAUT F., (eds.), The Making of Feudal Agricultures ?, Boston-Leiden, Brill editor, coll. The transformation of the Roman World, vol. 14, 2004, p. 177-253.

rainfall, the sheep folds of the Crau would have fulfilled «as their main function the need to shelter flocks of sheep from the end of the winter to the beginning of the summer» (Columeau 2000, 354-355). As for transhumance, it is safest to stick with the minimalist hypothesis of P. Coste and N. Coulet: the sheep of the Crau in the Roman period " spent their summers in the Camargue marshes, or in the neighbouring Alpilles or in the Lubéron, just beyond the Durance» (Coste and Coulet 1994, 65). Further, the discovery of sheep pens has opened a discussion that has become polemical. Indeed, at the same time, P. Gros, while studying some particularities in the architecture of the site of Glanum at the north piedmont of the Alpilles, during the hellenistic and Roman period, suggested that there, there was an assemblage typical of the sanctuaries-cum-markets associated with transhumance. Tax collection at a site of passage is thought to have been one of the reasons for the prosperity of the town (Gros 1996). This article caused a strong reaction from A. Roth-Congès, putting forward a number of objections, from a chronological, geographical and technical point of view and trying to re-instate the religious hypothesis (Roth-Congès 1997). These objections are of unequal weight. The chronological dispute in particular is open to discussion because the research in the Crau has shown precisely that the sheep folds dated to the Roman period, whereas the texts of Pliny and Strabo refer in general terms to flocks that may have existed far earlier and which applied to breeds of sheep that do not require built shelters. Furthermore, new archaeological research has shown that the site of Glanum extended beyond what was expected and was not confined to the monumental zone that is on display (Gazenbeeck. 1998).

It is in fact necessary to improve research on stock animals, in order to characterise them (types of breeds, duration of periods spent in stables,...) And to identify the paths they followed to their pastures. Here again geoarchaeological work conducted in the Rhône valley has brought new evidence: according to J.-F. Berger, in certain sectors subject to flooding and in the hollows of the Tricastin at north of Avignon and the Valdaine at east of Montélimar, drainage is abandoned from the end of the $2^{\text {nd }} \mathrm{C}$ onwards. The landscape is then altered by an increase in water meadows which would correspond to an extensive pastoral exploitation, which of course remains to be proven by archaeological findings (Berger 2001).

Situations differ from one region to the next. The Crau was pasture land for flocks from the Neolithic onwards, but, as we have seen, the Roman period is characterised by the establishment of stabling which is only found again in modern times. This difference can of course be explained by the nature of the Roman occupation in Provence and the place that the market economy occupies, that is to say by a change introduced into the region by Rome. In the Pyrenean mountains, historical ecology and the archaeology of pastures (Davasse et al. 1997; Galop 1998), make it possible to sketch a history of husbandry from the Neolithic to the modern period which does not exhibit any similar breaks in tradition. In French Catalonia, on the mountain of Enveig, archaeological records of levels dating to the Roman period show a pastoral occupation probably to be equated with farming occupation in the plain: it is likely that the former are summer pasture rather than transhumance sites. Thus archaeology comes to vindicate the hypotheses put forward by palaeoecologists for the history of the Pyrenean mountains; the opening of the forest picked up in pollen analyses must be related to the pastoral occupation of the mountain. In the long-term frequentation of the mountains, a history that starts in the Neolithic, the Roman period does not occupy a particular position. It exists as a continuation of a system of exploitation and use of space that goes back to the end of the Bronze Age and has very little impact on the mountain (Galop 1998, 257; Riera i Mora 1994). On the French side of the Pyrenees complementary, research on the lowland zones has not been undertaken. But an investigation of the plain of Barcelona, carried out by J. Palet i Martinez, can be consulted. During the period that is of interest to us, the development of the pastoral economy is characterised by the complementary nature of the delta wetlands, where pollen diagrams record the presence of flocks (Riera-Mora 1995) and the pastures of the mountain chain of Collserola. New road axes, used as drove ways, replace the roads of the Roman centuriation system and allow the plain to be crossed (Palet 1997). The topography is very different from that of Southern France: the Pyrenean mountains dominate directly the plain, whereas in Provence a long trek is necessary to reach the summer pastures from lower Provence.

In the hinterland of the Languedoc, further West in the Monts de l'Espinouse, a clear decrease in the level of tree pollen is recorded in the pollen diagrams of Font-Salesse and Baissecure between the $1^{\text {st }}$ and the $8^{\text {th }}-10^{\text {th }} \mathrm{C}$, although this phenomenon is not accompanied by a notable increase in the Mediterranean vegetation (Beaulieu 1969). On the contrary, in a region where the cultivation of cereals and trees (sweet chestnut, walnut) are still only recorded in places, the start of a continuous curve for plantain speaks for a pastoral use of these zones. From the $8^{\text {th }}$ $10^{\text {th }} \mathrm{C}$ middle-range transhumance begins to develop, under the auspices of the Benedictine monasteries established on the high plateaux and in the plain (Durand 1998, 362-370). The same situation exists in Catalonia. In the Po plain in Italy, middle-range transhumance also starts at around the same time, associated with indications that trees (mostly 
Article published in BARCELÓ M. et SIGAUT F., (eds.), The Making of Feudal Agricultures ?, Boston-Leiden, Brill editor, coll. The transformation of the Roman World, vol. 14, 2004, p. 177-253.

sweet chestnut) were also cultivated (Menant 1994, 249-287).

A number of palaeoenvironmental studies highlight the role of husbandry in mixed farming. In the Pyrenean part of the department of the Aude work on the peat bog of Pinet provides a good example (see above). According to charcoal analysis in the Valdaine, ash trees, which, like elm trees are used in husbandry, increase, probably because they were used to build hedges. But they are not the only ones. On the plateau of the Larzac, box trees are documented as being used in husbandry, particularly for lambs (litter, food), so much so that on can talk of a box tree culture. During the Carolingian period, the only known sites are located in the uplands, at the northern limit of the green oak forest. Human activity is recorded there. Botanical work by M. Farizier on a macro-flora preserved in limestone deposits (travertine) and radiocarbon-dated to the $11^{\text {th }} \mathrm{C}(1080 \pm 50)$, has revealed the presence of Coryllus avellana, which indicates an opening up of the beech forest during the period that precedes the establishment of the Carthusian monastery in 1205, a clearing that is greater in extent than today's (Farizier 1980).

\section{V.- - THE RURAL ECONOMY}

\section{1 - The populating of the countryside}

The traditional view of the populating of the countryside has been markedly modified by a better grasp of the dynamics of the landscape. It has permitted a review of the notion that the lowland zones had been deserted by showing that the absence of visible archaeological sites was due to their burial by later deposits. Research in the Vallée des Baux can be cited as one of the most accomplished examples (Leveau and Saquet 2000). This depression of some 1-2 km in width, separating the Alpilles from the Crau and defined by the $20 \mathrm{~m}$ contour, has been incorporated into the bed of the river Rhône following a process that probably started in the Middle Ages. As a result it constitutes an excellent observatory for the history of regional hydrological phenomena. The bottom of this valley is almost level with the sea-level and it would be a marsh if water was not permanently pumped out from it. Transformed into a polder after a century of drainage works, the valley is at present under cultivation. It has long been thought that the marsh had existed «at all times», in particular during the Roman period (Benoit 1940, 68). But sediment analysis and the discovery of a settlement (village ?) going back to the Copper Age have brought into question the notion of the permanent underwater status of this depression. Deposits corresponding to various hydraulic features of the valley have been correlated with written historical documents and archaeological data. It could be demonstrated that the horizontal nature of the valley was the result of the build-up of sediments masking a varied topography (Leveau 1999). Thus, contrary to what used to be written since F. Benoit, human occupation had not retreated towards the North at an early date, abandoning the valley bottom to rising water: the valley remained occupied until the $7^{\text {th }}-8^{\text {th }} \mathrm{C}$ (Bellamy and Hitchner 1996).

\section{a - The situation at the end of the Roman period}

Much has been made by Romanists of the end of the Roman world, a crisis whose origins were sought in the crisis of the $3^{\text {rd }} \mathrm{C}$. In the last ten years, a general re-thinking of the problem has led to and abandonment of the idea that there was a profound break in rural settlement between an ill-defined Early Medieval period and a far better studied Roman period in the Mediterranean regions. Then, battles and sieges affect the economy and have a depressing effect on the conditions of production and the economic networks. But the latter put up a fight. Archaeological research would now put less emphasis on the process of decline that was observed and forbids to present the end of the Roman period as a time of sudden break and a general collapse of the Roman infrastructure. One of the major advances in archaeology, and one that has made re-interpretation possible, has been the use of quantitative methods which increase our understanding of the real burden that society puts on the landscape. Archaeological surveys, conducted systematically and within a scientific and heritage perspective make it now possible to draw, sector by sector, distribution maps of given sites and to construct curves showing the appearance, the growth, the maintenance or the 
Article published in BARCELÓ M. et SIGAUT F., (eds.), The Making of Feudal Agricultures ?, Boston-Leiden, Brill editor, coll. The transformation of the Roman World, vol. 14, 2004, p. 177-253.

decline of different forms of settlement, «peasant settlement» or villa latifundia (Durand-Dastes et al. 1998, 74-114). Micro-regional characteristics can appear on these curves. Regions with dense Roman populations are broadly opposed to other regions where a farming economy of protohistoric origin and indigenous tradition is dominant. The density curves that have been drawn up, giving the number of sites per $\mathrm{km}^{2}$, show roughly parallel evolutions. " During the $4^{\text {th }} \mathrm{C}$, densities range between 0.11 and 0.92 sites per $\mathrm{km}^{2}$, for an average of 0.25 sites per $\mathrm{km}^{2}$. During the $5^{\text {th }} \mathrm{C}$, they range from 0.14 to 2.08 sites per $\mathrm{km}^{2}$, the average being 0.60 sites per $\mathrm{km}^{2}$. These values can be compared with those for the $1^{\text {st }} \mathrm{C} A D$ which range between 0.59 and 2.28 sites per $\mathrm{km}^{2}$, that is an average of 1.15 sites per $\mathrm{km}^{2}$ (Trément et al. 2001). There is therefore a real decrease in the occupation of the landscape, manifesting itself in the loss of a considerable number of Roman villae, in particular large villae with often ostentatious architecture and medium-sized or small villae which secure the weft of the landscape. This decrease is often of a qualitative nature. In Provence, where studies have been conducted, villae sites are indeed occupied during the $4^{\text {th }}$ $5^{\text {th }} \mathrm{C}$. But only a very small number of them has the status of villa (Carru et al. 2001). The others are not necessarily abandoned, but the nature of their occupation has changed. What remains of the occupied parts of buildings exhibits a drop in the standard of living. In fact, the situation is close to that described by P. van Ossel and P. Ouzoulias in Northern Gaul, to the extent that his observations merit to be applied to the whole of the territory of Gaul (Van Ossel and Ouzoulias 2000). In Northern Gaul, this development is accompanied by the appearance of a type of settlement different in its plan and organisation. In 1980, J. Chapelot and R. Fossier thought that buildings which were partly underground and partly above ground had been brought in by Germanic migrations from the Slavic and Germanic world where such structures are known (Chapelot and Fossier 1980, 131-132). Since, examples have been excavated in Southern France, in the Languedoc (Ginouvez 1993; Garnier et al. 1995; Mauné and Feugère 1999, 391) and in Provence (Bertucchi pers comm; Berato in Bertoncello 1999, 291). Therefore, one might be justified in asking whether the novelty lies in the type of construction or in its discovery! The difference is of importance: in one case it would be a real innovation and it could correspond to a Germanic settlement (Mercier and Raynaud 1995, 202), in the other it would merely confirm its use.

One element seems certain: in Narbonnaise Gaul, the phenomenon of the palatial villa has not experienced a growth equivalent to that exhibited in Aquitaine, in North-Eastern Gaul or in Spain in the $4^{\text {th }} \mathrm{C}$. The only known villa which is comparable is a villa maritima which has been known for some time, the villa of Les Beaumelles at SaintCyr-Les-Leques to the West of Toulon (Brun 1999, 639-652). The presence of urban elites is nevertheless well documented in the countryside. P. A. Février has been able to prove this from geographical lists (Février 1981), to which archaeological findings can be added. The best known villa is now that of Près-Bas at Loupian on the edge of the Etang de Thau reported on by $\mathrm{Ch}$. Pellecuer in a monograph that reconstructs its history from its construction in the early Roman empire up to its definitive abandonment in the $7^{\text {th }} \mathrm{C}$. The site sequence is meticulously reconstructed over the half millennium preceding the building of the architectural project that include the rich polychrome mosaics that have made the villa famous. Started at the beginning of the $5^{\text {th }} \mathrm{C}$, it entails a transformation of the local topography, however without breaking with earlier phases. The residential part is doubled in size. Whereas previously residential wings and courtyards were laid out following the topography of a slope cut into by small valleys, a new and vast platform is built. The buildings are arranged around a huge peristyle $(40 \mathrm{x} 26 \mathrm{~m}$ including the porticos). Archaeological finds (pottery, coins), combined with stylistic arguments suggest a date around $400 \mathrm{AD}$ for this building programme, a date which would roughly agree with the suggestion by $\mathrm{H}$. Lavagne (1981) that the building dates to the first quarter of the $5^{\text {th }} \mathrm{C}$. Excavations has not revealed agricultural buildings, which - just as the baths of this time - are located outside the confines of the villa, in the near or far neighbourhood. The ultimate period of occupation of the site is little known.

All in all, the situation does not evolve in a way that is different from other villa sites in the Narbonnaise, like that excavated at Saint-Julien-Les-Martigues (Rivet 1996, 97-111). But what is different is the chronology. At Près Bas, there is indeed evidence for the permanency of the residential occupation of the building for a very long time spam; the mosaics reveal that the rooms were occupied continuously. As in Northern Gaul, where such a trend has been observed by P. Van Ossel (Van Ossel 1992, 178), utilitarian and agricultural functions re-colonise certain parts of the building, where they replace residential functions. During the course of the $6^{\text {th }} \mathrm{C}$, the courtyard seems to have housed a hut. The gardens of the residence are no longer looked after. New buildings are erected, in particular sunken-floored structures similar to those discovered at Dassargues (Garnier et al. 1995, 36 and fig. 35). Thus Ch. Pellecuer has been able to bring to light evidence of an evolution also observed elsewhere, in particular at SaintAndré-de-Codols, where a villa site has been the subject of a large rescue archaeology operation (Fiches and Veyrac $1996,489-491)$. In the South, the real break in the occupation of the landscape is to be sought in the course of the $7^{\text {th }}$ 
Article published in BARCELÓ M. et SIGAUT F., (eds.), The Making of Feudal Agricultures ?, Boston-Leiden, Brill editor, coll. The transformation of the Roman World, vol. 14, 2004, p. 177-253.

\section{b. - The Carolingian destiny}

Medieval historiography of the 1980s and 1990s, dominated by the question of castles, proposed a unequivocal view of human endeavour prior to the year 1000: in that most classical of schemes inherited from the Italian case, peasants, up to then spread in makeshift settlements, were gathering together under the coercion of lords from the year $950 \mathrm{AD}$ onwards, inside purpose-built fortified settlements so that they could benefit from the benevolent but interested protection of the master. The birth of villages coincided with a will to assemble populations in order to control them better. In the Languedoc, M. Bourin has pointed out from early on that this scenario needed some adjustments: it described the Carolingian settlement pattern as open and dispersed, though not absolutely, with hamlets in the form of clusters or more rarely as tightly-knit communities. Within this very loose structure, the nuclei of the old Gallo-Roman vici and those of the cities remained. Similarly, in the growth of the castle network, the part of the ancient, Roman or Carolingian, inheritance is to be taken into account, even if the reorganisation of the settlement pattern was largely under way.

Archaeological research has come to refine, complement, even contradict the general framework, by demonstrating the growth of villages is a complex phenomenon. At Lunel-Vieil - the oldest and most thorough example - the excavations of C. Raynaud have revealed the hesitations and the fluctuations of the settlement between the $7^{\text {th }}$ and $11^{\text {th }} \mathrm{C}$, highlighting the problem of weak discontinuities in the built environment while the site remains occupied continuously since the Roman period. The organisation of this village is slow and takes place over a long time around the church area (Raynaud et alii 1990). In the Vaunage and the canton of Mauguio, at west and south of Nîmes, A. Parodi, C. Raynaud and C. Mercier have demonstrated the existence of nuclei of grouped settlements before the year 1000, which, though modest, survive beyond the year 1000, to die out with the new trend for castles in society. A more careful re-reading of Carolingian written documents endorses this point of view: the term in ipsa villa, following in the same sentence or at the beginning of the next the expression in villa de, shows that the word villa means at the same time a tract of land cultivated by peasants and a specific place located within this land, where a settlement has started to nucleate (Bourin and Durand 1994). The use of topographic descriptors such as super or subtus reifies in the landscape this polarisation of space by taking into account one of the elements of the landscape, its contours. Further, a large number of castra of the year 1000 are conceived initially as the inheritors of a mothervilla, reflected in the place-names in -an or -argues. The simultaneous use of two terms, villa and castrum, in the same place-name in the same document reveals the dual nature of the settlement and the bi-polar use of space, in ipsa villa on the one hand, around a castrum on the other hand.

The importance of the late Roman inheritance of the $3^{\text {rd }}$ to $6^{\text {th }} \mathrm{C}$ in the formation of the Carolingian settlement framework is well established today, through cross-reference of a number of sources. But this continuity of nucleated or even closed settlements (Raynaud et al. 1990) does not signify an immobile situation: without going as far as mentioning an itinerant pattern, it must be stressed that the anchorage of the built fabric to specific localities is not yet definitively achieved; the polarisation of the Carolingian rural space is the beginning of a long process of burgeoning settlements reaching a plateau with the birth of villages in the $11^{\text {th }} \mathrm{C}$. These continuities or weak discontinuities do not exclude foundations like Augery-de-Corrège $\left(9^{\text {th }}-11^{\text {th }} \mathrm{C}\right)$ in the Camargue, which could be a village colonising marshy zones or former salt marshes. At least this is one possible interpretation. These grouped settlements are still very loosely knit: the settlement buildings of Augery are grouped around enclosed spaces interpreted as courtyards or kitchen gardens and they form the centre of the nucleus. Grouping is also open, flexible and articulated around fields at Dassargues. It therefore appears that the structural organisation of these early forms of villages is rough and ready, even rustic, corresponding to what J.-M. Pesez calls «infraconstruction».

Archaeological evidence has also come to re-evaluate the weight of secular fortifications in the genesis of villages: in Catalonia first, then in the Languedoc in the department of the Aude, and later in the departments of the Hérault and Gard, historians and archaeologists have contrived to describe the "ensagrerament», that is to say the spontaneous congregation of people around the circle of peace of churches, defined as a radius of 30 paces around the ecclesiastic building, in order to protect itself against the violence and increasing demands of milites during the advent of the tying of common men to the lord's fief (Baudreu, Cazes 1994; Catafau 1997). In the higher Herault valley, the Carolingian diplomas of the monasteries of Aniane and Gellone also record closed groupings up people around a cult centre. Thus the role of the church and cemetery in the polarisation of the Carolingian rural space has been largely rehabilitated in the last ten years: research activity in the South is at present focused on this subject.

Motte and bailey castles have long been considered as typical of the northern half of Europe. Supported by a national inventory programme on earthen fortifications, research has demonstrated that this feature was also presents 
Article published in BARCELÓ M. et SIGAUT F., (eds.), The Making of Feudal Agricultures ?, Boston-Leiden, Brill editor, coll. The transformation of the Roman World, vol. 14, 2004, p. 177-253.

in Provence and Languedoc : C. Castelvi (1984) in Roussillon,, M. Dauzat (1983) in Lauragais, M. Fixot (1975) and D. Mouton in Provence, P.-Y. Laffon (1998) in Vivarais have listed a not negligeable number of mottes. If some reuse or re-cut natural contours, others respond well and truly to the strictest definition of the phenomenon. In chronological terms, it begins in the $10^{\text {th }} \mathrm{C}$ and ends during the course of the $13^{\text {th }}$. Generally featuring wooden constructions and surrounded by storage structures, notably numerous grain storage silos, these mottes have been recognised as part of a timber and earth tradition. Indeed, if J. Chapelot and R. Fossier remained relatively cautious in 1980, writing that in France and Italy «due to the paucity of excavations, it is difficult to establish the age of this rural stone building tradition, especially in the Mediterranean zone»; they noted, however, the fact that the analysis of documents dating to a period prior to the $12^{\text {th }} \mathrm{C}$ recorded stone houses more frequently than timber houses and concluded that stone houses were closely linked to the southern limestone zones of Europe. Since at least the last decade, archaeology has come to contradict such a chronology: during the early Middle Ages as afterwards, medieval houses of earth, timber, mud or wattle and daub existed also in the South, and not just in the Camargue.

\section{2 - Major land organisations}

The setting out of land boundaries, roads and drainage, which give to the landscape an enduring framework, were determined by two objectives. The first is economic and consists of the establishment of newly cultivated land and the opening up of the region. The second is constituted by taxation, based on land boundaries. Neither of these two objectives are, a priori, the prerogative of a specific period. But there seems no doubt that in the Roman period particular attention was paid to the system of centuriation, whose establishment and destiny has played an essential part in research.

\section{a. - Orthogonal and concentric land boundaries}

The Roman conquest resulted in a vast agrarian restructuring which affected most parts of the plains of Provence, the Languedoc and the valley of the Rhône. In its outline, the Roman landscape remains profoundly marked by this heritage. The publication by A. Piganiol of the Roman marbles of Orange, which give the plans of three centuriations in the Rhône valley, followed by the research of M. Clavel-Lévêque on Béziers, together with, in more general terms, the remarkable work of the Besançon geomorphologists have permitted and estimate of the surfaces involved. The Romans were of course not the only ones to have resorted to geometric divisions into plots of the territory. But in the South of France, they were the only ones to have conceived and put into practice such an organisation over hundreds of $\mathrm{km}^{2}$. The discovery of fossil centuriation systems has therefore been greeted unanimously by historians as a major feature. Two millennia later, the traces of this organisation continue to mark the landscape, undoubtedly to a lesser degree than in Africa or in Italy, in Campania or the Po plain, but sufficiently clearly to be visible on vertical air photographs and recorded on topographic maps.

At present, research is able to delve deeper into the evidence. In the Rhône valley, work on the cadastres of Orange continues. The three known cadastres are now fairly securely located. Two of them can be pinpointed with certainty: the «Cadastre B» since the publication of A. Piganiol (Piganiol 1962) and the «Cadastre A» since the research undertaken by G. Chouquer in 1981 (Chouquer 1981). The «Cadastre C» has recently been the subject of convincing arguments that vindicate a suggestion of A. Piganiol (Christol et al. 1998). In the Languedoc, the research carried out on the cadastres of Béziers have resulted in the publication of an Atlas (Clavel-Lévêque 1995). These results have generally enabled us to evaluate the complexity of the evidence for superimposition and enmeshment of the centuriations, related in the texts of the Gromatici. Thus, in the Languedoc, in the territories of Roman colonies, but also in territories dependant on Latin law such as Nîmes, extensive research has been able to isolate a sequence of successive centuriations on the palimpsest of the landscape. Impressed by the success obtained by antiquarians, G. Duby presented centuriation as a «vast net, whose fine mesh was thrown by Rome over the peasantry of Gaul» (Duby 1975, 30).

But matters did go adrift, as such images justified a simplistic method which consisted of casting grids onto maps and ending up with a multiplicity of geometric boundary systems attributed systematically to Roman colonisation, while concentric land boundaries were considered as medieval. This approach is absurd, as it aims to 

Brill editor, coll. The transformation of the Roman World, vol. 14, 2004, p. 177-253.

attribute to the shape of land boundaries a chronological value. Generated as convenient plots, orthogonal divisions are indeed the basis of all space management on a large scale by a strong power. By contrast, rural communities will create a landscape whose circular character is due to the polarisation of fields towards a central point, the village or the farm. Ease of access to fields favours such an arrangement in a period in which power is splitting up. A priori, it should not be impossible for a central power to allocate plots on a circular model: it has been used in the history of European urbanism (Fabre et al. 1996). But concentric forms could just as easily have existed during the Roman period in sectors where the underlying pattern had been respected, while orthogonal layouts had been used in the preRoman period in our regions by Phocean colonists and, in the Middle Ages, on newly colonised land. Orthogonal and polarised structures refer first and foremost to social formations - which could coexist - ; in second place only, can this phenomenon be interpreted in chronological terms. It nevertheless remains true that non-orthogonal landscape forms are more characteristic of protohistoric and medieval landscapes, whereas the orthogonal treatment of territories represents an «event», such as the imposition of power from Rome over Southern Gaul.

Like all «crises», that which affects archaeo-morphological research does not only have negative effects (Leveau 2000). Growing attention is being paid to the decay of the geometric framework associated with five centuries of use of land and tracks and to the relationship between land boundaries and the natural environment. The complexity of the situation is becoming increasingly apparent. Some researchers have sought a confirmation in the field by excavating fields and revealing traces of ploughing, ditches and field boundaries of centuriation systems. The burial conditions («taphonomy») of field boundaries or the reasons for their destruction through erosion constitute a precise research target, tackled in collaboration with environmentalists. The latter have been able to incorporate into archaeological operations, physical variables associated with sedimentary deposits likely to bury archaeological features. Research protocols put in place on large excavations, such as those occasioned by the construction of the regional airport of Lorraine have been applied to certain sectors of the excavations on the TGV Méditerranée line in the Rhône valley in the area affecting the Cadastre B, the best documented of the three cadastres of Orange. Through cross-reference between the data obtained by the three disciplines involved in this research - archaeological data referring to soil occupation, archaeomorphology and geomorphology - it is possible to refute objections levelled at the method (Chouquer 2000). Geomorphological studies have been instrumental in establishing the phases of use of drainage networks and for comparison with the results from the various palaeoecological, geomorphological and soil studies. Knowledge of the theoretical frameworks of centuriation has enabled us to understand the diversity of «their initial materialisation (ditches, buried drains, tracks, hedges) and later to sketch their role and function (drainage, irrigation, communication or protection from the wind)» (Berger 1999). In the plain of the Rhône, in the Tricastin, in the locality of Malalones in the parish of Pierrelatte, J. Berger and C. Jung have been able to follow the history of a ditch belonging to the Cadastre B of Orange. Regularly cleaned and recut in the Middle Ages, it was finally obliterated by later deposits. But, remarkably, its line was preserved by a later hedge (Berger and Jung 1996, 100 fig. 5). This example vindicates archaeological research procedures while also demonstrating the determining role played by collective memory in the preservation of land boundaries: in its outline, the modern landscape has inherited ancient forms. Archaeological investigations allow the threads of complex orientations to be unravelled in areas where written sources are not available. Centuriation affected the whole of the plain of the Rhône South of the Roman colony of Orange. The plain of Arles was also subjected to a centuriation system, only known up to now through the orientation it has imprinted on the land boundaries. The cadastre of Orange stops at the foot of the Alpilles, some ten kilometres North of where the town of Arles was established. At present, no network of tracks and ditches comparable to those known in the plain of Orange has been identified through aerial reconnaissance or excavation.

At present, the best example outside that of the plain of Orange is located in the region of Lunel-Dassargues, on the right-hand bank of the Vidourle between the Camargue and the Garrigues of Nîmes, where orientations picked up in excavated areas are probably linked to three centuriations in the territory of Nîmes, already highlighted in studies of agrarian morphology (Favory 1996). The network of ditches that reveals these territorial divisions was in use up to the end of the $4^{\text {th }} \mathrm{C}$ at the latest. Ins pite of being backfilled, the orientation of these ditches continue to structure the landscape up to the $7^{\text {th }} \mathrm{C}$ : hedges and wooden fences replaced them. A farm and a small cemetery of a few graves were established in this context. There is little archaeological evidence for the Carolingian period, although an $8^{\text {th }} \mathrm{C}$ text refers to the existence of a church and houses (Garnier et al. 1995).

All in all, recent research has come to confirm the hypothesis of J. Chapelot and R. Fossier of some twenty years ago: «In the South of France, the maintenance of Roman land boundaries, at least in large areas, can be explained probably by an exploitation of the landscape so much imprinted upon the terrain that an early medieval 
Article published in BARCELÓ M. et SIGAUT F., (eds.), The Making of Feudal Agricultures ?, Boston-Leiden, Brill editor, coll. The transformation of the Roman World, vol. 14, 2004, p. 177-253.

agricultural exploitation did not alter it» (Chapelot and Fossier, 1980, 70). Advances in archaeological techniques enables current research on the rural world of the Early Middle Ages to review the image of deserted landscapes that prevailed in the past. The image of a general abandonment is to be rejected. But this does not necessarily mean that sectors whose cultivation required rigorous management and important means continued to be exploited.

\section{b. - Agricultural water management}

Research by S. Caucanas on mills and irrigation in the Roussillon from the $9^{\text {th }}$ to the $14^{\text {th }} \mathrm{C}$ represents the most recent overview on the question of water management in the South of France. Its origins are obscure: historiography hesitates between a Roman, Wisigothic or Arabic origin (Caucanas 1995, 20). But, in the absence of precise and explicit archaeological or historical evidence for mills and irrigation systems, it is impossible to decide. The study of the first texts, dated to a time spanning the $9^{\text {th }}$ to $11^{\text {th }} \mathrm{C}$, leads Caucanas to highlight the relationship between agricultural water management and the construction of water mills: it appears to be a relatively common practice. Irrigation of gardens on a small scale has been a feature of farming since the origins of agriculture in agrarian societies, whatever their technical level; there are no reasons for thinking that this was no longer the case. But a real innovation appears at the beginning of the $11^{\text {th }} \mathrm{C}$ in the form of canals « which are no longer just considered a profitable but ancillary means of increasing the income of an estate: on the contrary they are now regarded as essential, even paramount and fundamental for the exploitation of the land» (Caucanas 1995, 27). In the light of documents describing the situation in the decades prior to the year 1000, S. Caucanas concludes that «everything leads us to believe that constructions of this type were already in existence during the preceding centuries». There is no cause for surprise: such arrangements are known in the Iberic peninsula since Roman times (Gorges and German Rodrigez Martin 1999).

An identical situation is visible in the neighbouring Languedoc: the existence of veritable hydraulic systems can be linked to the mastery of irrigation from the beginning of the $9^{\text {th }} \mathrm{C}$ : before the year 1000 , around $30 \%$ of mills are equipped with systems for watering the land; this percentage is truly eloquent, considering that these are the beginnings of the mechanisation of the landscape (Durand in press). Furthermore, particularly in the lowlands in the zones of marshland or former salt marshes, a number of fields are passed on vallo in medio, but it is not possible to decide whether this refers to a drainage system or an irrigation system or both together. Field archaeology confirms the vision offered by the history of water management given in written documents. At Augery-de-Corrège there are numerous salt water canals on the Carolingian settlement site. The purpose of land snail analysis, undertaken by J. André, on a number of negative features, was to differentiate between their origins, functions and time of use, such as drainage structures, foundation trenches or tracks. Thus, she has been able to recognise beside dry ditches which had later been rapidly backfilled, drainage ditches which held stagnant water and which were periodically flooded. Results from charcoal analysis, which record salt-loving and humidity-loving species with monocotyledons, do not contradict these findings (Kotarba et alii 1987). Research undertaken by C. Raynaud on the territory of Dassargues has also shown the presence of irrigation and drainage ditches associated to traces of fences and hedges and to plantation furrows: they allow the reconstruction of the limits of a few hectares of a farm established at the beginning of the $6^{\text {th }} \mathrm{C}$ on the banks of the Vidourle (Andre et al. 1997, 109-113). Irrigation on a small scale is thus well recorded in the farming economy in Provence as well as in the Languedoc.

In the latter region, contrary to what $\mathrm{S}$. Caucanas records in French Catalonia, there is still no evidence that irrigation on a large scale existed in the Middle Ages (Bourrin-Derruau et alii, forthcoming). J. Béthemont had already noted that, just as in the rest of the Rhône valley, large scale irrigation was only developed in Basse Provence in modern times,, when the canal of Craponne is built (Béthemont 1972). In the Comtat Venaissin, where the management of water became of particular importance, the historian P. Fournier has recently dated the beginning of the process to the end of the $16^{\text {th }} \mathrm{C}$, a process that ends up with the large scale irrigation of the $19^{\text {th }} \mathrm{C}$ (Fournier 1999 , 24-25). P. Fournier accepts that there was an «acceleration» of the process in the Middle Ages but not a «break». The documentation which he consulted gives an impression of a constant improvement of procedures needed to control water. Archaeological work is able to contribute new data to this subject. For the Roman period, large scale irrigation, that is to say the construction of structures able to collect, conserve and distribute water to fields on the scale of a whole valley or a plain, was only known in drier regions of the Empire and perhaps in Italy (Quilici-Gigli 1989; Thomas and Wilson 1994). J.-F Berger and C. Jung suggest they have identified a Roman irrigation network at 
Article published in BARCELÓ M. et SIGAUT F., (eds.), The Making of Feudal Agricultures ?, Boston-Leiden, Brill editor, coll. The transformation of the Roman World, vol. 14, 2004, p. 177-253.

Bartras in the parish of Bollène in the Tricastin, based on a study of the typical sandy fills of the ditches (Berger and Jung 1993, 103-105). Thy appear to have established the presence of large scale irrigation in the Roman period which disappears from most areas during the Middle Ages. However hydraulic knowledge was passed on into some historic documents of the Languedoc dating to the $11^{\text {th }}-12^{\text {th }} \mathrm{C}$ and mentioning fossatos antiquos, apparently in working order. Used in a specific context, the adjective antiquus refers to a stone-built structure rather than to just a ditch or vallum. The Roman period is the most likely.

The scattered information available for the history of water mills points in the same direction. Im the Catalan Pyrenees, V. Izard argues convincingly that the use of water wheels in the context of iron metallurgy goes back some three centuries earlier than thought, that is to around the year 1000 (Izard 1999). In her eyes, this is a veritable technological revolution. It is therefore unlikely that hydraulic techniques had disappeared completely.

The data concerning systems of sluices or outlets speak in general in favour of a preservation of the knowledge required to operate drainage and irrigation on a large scale. Thanks to such systems, the many enclosed depressions that are scattered throughout the calcareous plateaux of Southern France, in Provence as well as in the Languedoc, were put into cultivation, as has been recorded on air photographs: anomalies in land boundaries continue to indicate the shape of these hollows, now almost all drained. Following the research that he has conducted on the wetlands of the eastern Languedoc and on the closing of the lagoon of Narbonne, P. Ambert has recently directed research in the valley of the Aude which opens new perspectives for the history of the landscape in the Roman and Medieval periods. Under the aegis of the Centre d'Anthropologie de l'Ecole des Hautes Etudes at Toulouse and the directorship of J. Guilaine, the lower valley of the Aude between Carcassonne and Narbonne has been the subject of a borehole survey. Meanwhile P. Ambert assembled a palaeoenvironmental team which examined a series of closed depressions isolated from the regional river network and which were naturally marshy, and therefore likely to give a good record of the evolution of the local environments. Some hollows had been developed during historic periods, with tunnels or canals dug into the subsoil to drain them (Ambert 1995, 221). The possibilities for observation and analysis offered by these depressions have been known for some time. They contain, preserved in them, remains of constructions, in particular trenches or outlet tunnels, which are roughly equated with the Roman period or with medieval land clearance. Considering that these are periods in which the techniques of mining have been mastered, canal construction is of no great technical difficulty.

An interesting example of drainage work identified at Suze-la-Rousse in the department of the Drôme, in the Tricastin, has been the focus of some suggestions from P. Poupet. An underground structure maintains at present the drainage of a depression located in the parish of Suze-le-Rousse, being the successor to drainage works carried out in the $17^{\text {th }} \mathrm{C}$ : but the marsh kept returning. The first interventions are mentioned in texts of the $11^{\text {th }} \mathrm{C}$. Yet the depression belongs to a zone known to have been cultivated during Roman times and integrated into the area of the cadastre of Orange (Poupet 1994). A similar focus was brought to the are surrounding the ancient site of SaintBlaise, on the western side of the Etang de Berre, where F. Trément has studied a number of small depressions. For this zone, there are numerous archaeological and historical records which allow the fluctuations of water levels to be put in relation with the rhythms of occupation of the land and with large scale drainage works which are probably datable to the Roman period (Trément 1999a and b). Further research is being undertaken, in particular on two depressions crossed by the new TGV line at west of Avignon, at Tras-le-Puy (Arthuis and Ambert 1997) and Pujau, where a sluice tunnel is known to have existed.

Traditionally, it used to be thought that these drainage works were the work of powerful individuals or ecclesiastic communities able to command sufficient political and financial support, wanting to increase their arable land or hay meadows on soils with high potential. No doubt this is the case for the most extensive interventions. During the $13^{\text {th }} \mathrm{C}$, the drainage of the depression of Montady near Ensérune in the country of Béziers is indeed presented as the proof of the renewed dynamism of an association of citizens (Bourin 1987, 2, 16). But it is likely that research has been too influenced by extreme examples, the most famous being the drainage of the Fucine lake which required the outlay of the Emperors of Rome and later in the Middle Ages the investment of their Germanic successors to maintain and refurbish this drainage. Too little attention has been paid to smaller scale works. A brief note on this subject by N. Coulet is dedicated to the drainage of a small depression in eastern Basse Provence by a single carpenter! (Coulet 1993). Finally, the remark made by S. Caucanas in relation to irrigation can equally well be applied to drainage: the initiative for the construction of these water works is due to «the owners of estates, as much the rich landlords as the small landholders» (Caucanas 1995, 31). In this perspective, the study of land improvements, large or small, of their operation and maintenance is an avenue to explore in order to evaluate the will and the ability of societies to master their environment. 
Article published in BARCELÓ M. et SIGAUT F., (eds.), The Making of Feudal Agricultures ?, Boston-Leiden, Brill editor, coll. The transformation of the Roman World, vol. 14, 2004, p. 177-253.

\section{c. - The management of slopes}

A similar type of question can be asked of cultivated terraces used to manage slopes. At a time of great demographic pressure, these developments extend agrarian surfaces on sloping terrain and maintain a relative humidity. As a result, they stabilise the slopes and help minimise the effects of erosion. In the majority of cases, these terraces do not last long if they are not maintained, perhaps some dozen years, unless they have been buried at the base of slopes. Thus, against the hopes entertained in the 1970s that the presence of this type of development could be established and that one day archaeological excavation would reveal its traces, many archaeologists in the South of France have reacted negatively towards such a proposal. Neither have the methods used by plant geographers proved useful in apprehending the history of ridge and furrow agriculture. In Southern Gaul the technique of terrace construction had already been mastered by Iron Age populations adept at building ramparts. The question has been taken up again by P.Poupet who, in opposition to general opinion, has been able to establish convincingly that slopes have been managed since the protohistoric period on a site occupied by the old Benedictine quarter in Nîmes. He concludes: «The slope of the Mont Cavalier, on the site of Les Villégiales has been cultivated in fields staged along a terrace system between the $4^{\text {th }} \mathrm{C} \mathrm{BC}$ abn the beginning or middle of the $2^{\text {nd }} \mathrm{C} B C »$ (Poupet 2000, 37). No similar research has yet been published nor envisaged for the Roman period, although it could be undertaken by archaeological teams. It is a question of seizing opportunities. Most archaeological operations capable of taking into account such a research objective have been carried out in the plains. Where it could have been possible to study terracing, namely in certain sectors touched by the construction of the TGV Méditerranée line, it has not been considered a priority by those responsible for operations. This is what happened in a section located between the valley of the Durance and the basin of Aix-en-Provence, where the line ran through a landscape which archaeologists and geomorphologists from the University of Aix had just studied.

The question of terraces was becoming a major archaeological challenge. It would permit to apprehend on an archaeological basis, for the protohistoric period, the question of the density of the indigenous farming population on the periphery of the domain of Marseille and, for the Roman period, the question of a potential reflux of populations towards the higher ground and of an exploitation of slopes in zones integrated into the Roman agricultural system (Leveau 1993, 34). For geomorphologists, the question was to assess the place of human factors in erosion processes during the last two millennia (Jorda 1993).

These are the questions tackled by F. Bertoncello and M. Gazenbeek in the Massif des Maures on the rock of Rochebrune which overlooks the valley of the Argens near Fréjus. There, huts and terrace walls of protohistoric date had encouraged the creation of soil accumulations against or on them (lynchets), on which new occupants settled in the late Roman period, reusing these structures. «Since the abandonment of the site in the $6^{\text {th }}$ or $7^{\text {th }} \mathrm{C}$, inspite of their partial collapse, these structures continue to retain soil on the slopes» (Bertoncello and Gazenbeek 1997, 619). A small village has been surveyed by F. Bertoncello and M. Gazenbeek on the rock of Rochebrune. Samples were taken and the pollen analysis undertaken by Bui Thi Mai shows that in the $5^{\text {th }}$ and $6^{\text {th }} \mathrm{C}$ human activity had somewhat diminished compared with earlier periods.

The author of a remarkable study of the genesis of landscapes and farming communities in Europe in modern times, Ph. Blanchemanche, had called the attention of archaeologists to the absence of mentions of cultivation terraces in historic documents (Blanchemanche 1990). In fact, a few texts dating to the Roman period mention terraces (Poupet 2000, 38). But it is not easy to track down terraces in written medieval sources. In the absence of descriptions in acts, only indirect references can be traced. The first and most secure approach consists of following the term «faïsse» (faissa, faxia, fascia) which bears witness to the development of slopes in a series of chartularies. In the Languedoc, the earliest mentions of «faïsses» date back to the $9^{\text {th }} \mathrm{C}$, but the zenith of the phenomenon takes place towards the end of the $11^{\text {th }} \mathrm{C}$, following an increase in population. The term «faïsse» itself encompasses a whole range of different structures and different types of cultivation. It describes steps on rocky slopes as well as terraces on the slopes of garrigues or even, and that is its main meaning, long narrow strips of land established along lagoons or water courses. Indeed, farming on slopes is not just concerned with steep slopes of the hinterland: it develops also and foremost in humid environments, along the edges of rivers, using as its base the contours of quaternary terraces sculpted into steps. The process is well understood: from around the year 1000, the colonisation of river banks following woodland clearance incorporate into the ager land dedicated to intensive cereal cultivation which requires drainage, banking or tree planting, using sometimes very specific procedures such as manuring or revetting with grass or turf. But if historical sources shine a fairly strong light on certain aspects of terrace cultivation, they remain silent on other types of development. Yet, from the end of the $10^{\text {th }} \mathrm{C}$, terms 
Article published in BARCELÓ M. et SIGAUT F., (eds.), The Making of Feudal Agricultures ?, Boston-Leiden, Brill editor, coll. The transformation of the Roman World, vol. 14, 2004, p. 177-253.

(prepositions) meaning a change of level are becoming increasingly frequent in descriptions and naming of goods, and strips of land located on or next to puechs (hilltops) are also more common. The long and laborious work of transporting stones and building with stone and earth is not recorded more precisely in written sources: the absence of exploitation contracts or of collective charters suggests that it must have been mostly individual constructions.

\section{Conclusion}

The image of the landscape in the Mediterranean South during the second half of the first Millennium that we have been able to present appears to show the sense there is in adopting an approach that integrates palaeoecological data. At the level of data useful to a historical reflexion, whether they are land units, archaeological sites or agricultural produce, the gain is obviously considerable. But this approach has not just the effect of bringing more data or more precise data to light. An ecological history implies a reinstatement of the «long time», a slightly outdated concept since the rehabilitation of the history of events. Ecological history gives pride of place to the notions of usage and inheritance. The concept of the first known use permits in particular to avoid falling into the trap of over-interpretation of an archaeological discovery or of negative evidence and similarly to avoid underestimating a given period. The examples concerning the use of water mills, of iron metallurgy or of terrace cultivation constitute good illustrations. Historians and archaeologists alike are led to abandon simple evolutionary models consisting of progress from «protohistory» to the «Roman period» to the «Dark Ages» to the «Middle Ages». In breach with a mythical image that portrays Romanitas from which the Middle Ages were breaking off, they insist on the notion of inheritance. Research has shown that, thanks to internal developments and to influences originating in the eastern Mediterranean, the foundations of the farming economy had been laid down during protohistoric times: plant cultivation, animal husbandry, tools, techniques of cultivation, management of the soils (drainage, irrigation, terrace building) form these bases. They continue to exist during the early Middle Ages. The principal novelty introduced by Rome consists of the integration of the region into the commercial economy of the whole Empire. The political and military crisis that accompanies the fall of Rome has had disastrous consequences. But it does not entail a retreat or a regression. Much of what has been acquired remains, broadly paving the way for a take-off in the early Middle Ages, succeeded by the great expansion of the centuries following the year 1000. The growth in farming in the $8^{\text {th }}-9^{\text {th }} \mathrm{C}$, resting on a demographic increase combined with intensive land clearance episodes, owes much to the preceding centuries: the change resides more in the intensification than in the introduction of new features.

Archaeological analysis allows us to step back from making obviously simplistic generalisations. At the micro-regional scale, two agricultural economies coexist, a farming economy that has its roots in a protohistoric tradition, and an organised economy ruled by profit («capitalistic"). Just as any other region, Southern France is not a homogeneous block. In the Roman period, the notion of heterogeneity in space enables us to integrate the opposition between the Roman and indigenous worlds, an opposition that has preoccupied many archaeologists. In the history of environments, it is not possible to talk in general terms of the impact of humans on the natural environment: the concept of anthropisation must be used at the level of the history of the societies being studied (Leveau 1997). Such is also the case in societies. Thus the administrative, social and economic aspects of romanisation can be distinguished. In Narbonnaise Gaul, as in the other provinces during the Roman period, irreducible economic forms exist side by side. «Rome» signifies in the first place a chronological period; in the second place it qualifies a social formation that has at its disposal means of intervention whose efficiency and whose impact on the environment have no common measure with the preceding protohistoric societies. The term «Protohistory» contains the same ambiguity: first of all it also identifies a chronological period and secondly a type of economy or a social formation that is otherwise qualified as «indigenous». The administrative integration of a geographical zone into the Roman province does not necessarily translate itself into the adoption of methods of space management that are encountered in the more developed sectors - the territories of the Roman colonial foundations for example. This way of reasoning also applies to the Carolingian period. Historians have already underlined on a number of occasions the heterogenous character of Frankish constructions, notably in Septimania and in Provence where Hispanic, Germanic and GalloRoman influences are encountered. One of the great merits of the dynasty of Pippin the Brief, Charlemagne and his 
Article published in BARCELÓ M. et SIGAUT F., (eds.), The Making of Feudal Agricultures ?, Boston-Leiden, Brill editor, coll. The transformation of the Roman World, vol. 14, 2004, p. 177-253.

successors is to have attempted the unification of the Frankish kingdom and later empire, the first form of the future Europe. On an economic level, Carolingian legislation, by means of capitularies, offers a model of organisation, that of the great estate, which possibly may never have been viable nor even attempted, if one follows its most fervent critics. Therefore, the term «Carolingian» exhibits the same ambiguity as «Protohistory» or «Romanisation». There is no Carolingian economy in the strict sense of the term, but the coexistence of different forms of spatial organisation and exploitation of the land. Bio-archaeological analyses demonstrate that any attempt to construct models on this subject is illusory and reaffirm the processes of human interaction with the landscape in all its complexity.

Finally the concept of transition applied to our period must be criticised. The archaeology of the landscape and of the land shows clearly how much this primitive notion is inadequate and useless. Indeed the historical vocabulary does not have another specific term to designate the span of time between the $4^{\text {th }}-5^{\text {th }} \mathrm{C}$ and the Carolingian period: this hybrid situation is a perfect reflexion of a historical study that leads nowhere.

Translated by Madeleine Hummler, January 2001 
Article published in BARCELÓ M. et SIGAUT F., (eds.), The Making of Feudal Agricultures ?, Boston-Leiden, Brill editor, coll. The transformation of the Roman World, vol. 14, 2004, p. 177-253.

\section{BIBLIOGRAPHIE}

ACHERKI N. (1997). Analyse palynologique de quatre carottes du Golfe du Lion. Application à la restitution de la végétation et du climat du Midi de la France pendant le dernier cycle climatique et à la stratigraphie marine. Thèse, Université de Montpellier II, Sciences et Techniques du Languedoc, Montpellier, 158 p.

ALEXANDRE P. (1987). Le climat en Europe au Moyen Age. Maison des Sciences de l'Homme, Paris, 827 p.

AMADO C. (1977). La seigneurie des mines en pays de Béziers et en Razès. Analyse de trois documents de la seconde moitié du XIIe siècle. In : Mines et mineurs... 1977 : 123-144.

AMBERT M. (1986). Le milieu naturel des étangs à l'époque médiévale. In : Les étangs à l'époque médiévale... : 19-28.

AMBERT M., AMBERT P., LUGAND M. (1993). Le littoral des départements de l'Aude et de l'Hérault. Atlas des changements des lignes de rivage en Méditerranée occidentale au cours des 2000 dernières années.

Archéologie en Languedoc, 17 : 126-134.

AMBERT P. (1995). La branche orientale du delta de l'Hérault ou de l'insularité du volcan d'Agde à l'époque grécoromaine. Hypothèses archéologiques et données géologiques. In : ARCELIN et al. 1995 (Études Massaliètes 4) : $105-112$

AMBERT P. (1995). Le couloir de l'Aude entre Carcassonne et la mer. In : GUILAINE 1995 : 221-224.

AMOURETTI M.-C., BRUN J.-P. and EITAM D. (eds.) (1993). La production du vin et de l'huile en Méditerranée. École française, Athènes, $339 \mathrm{p}$.

AMOURIC H., THERNOT R., VACCA-GOUTOULLI M., BRUNETON H. (2000). Un moulin à turbine de la fin de l'Antiquité. La Calade du Castellet (Fontvieille ; Bouches-du-Rhône). In : LEVEAU and SAQUET 2000 : 261 274

ANDRÉ J., CHABAL L., BUI THI MAÏ, RAYNAUD C. (1997). Habitat et environnement autour de l'Etang de l'Or au premier millénaire. Revue Archéologique de Narbonnaise, 30, 85-121.

ANDRIEU V., BRUGIAPAGLIA E., CHEDDADI R., REILLE M., BEAULIEU J.-L. (de), BARBERO M. (1999). A computerized data base for the palynological recording of human activity in the Mediterranean basin. In : LEVEAU et al. 1999 : 17-24.

ANDRIEU-PONEL V., PONEL P., BRUNETON H., LEVEAU P., BEAULIEU J.-L. (de) (2000 a). Palaeoenvironments and cultural landscape of the last 2000 years reconstructed from pollen and coleopteran record in the Lower Rhône Valley, southern France. The Holocene 10, 3 : 341-355.

ANDRIEU-PONEL V., PONEL P., JULL A.-J.-T., BEAULIEU J.-L. (de), BRUNETON H., LEVEAU P. (2000 b). 10000 years of vegetation history in Lower Provence revealed by the pollen analysis of two new sediment profiles from Marais des Baux. Vegetation History and Archaeobotany, 9 : 71-84.

ARCELIN P, BATS M., MARCHAND G., SCHWALLER M. (eds) (1995). Sur les pas des Grecs en Occident, Études Massaliètes, 4, 492 p.

Archéologie et espace, Actes des rencontres des 19-20-21 oct. 1989, APDCA, Juan-les-Pins, (1990), 523 p.. 
Article published in BARCELÓ M. et SIGAUT F., (eds.), The Making of Feudal Agricultures ?, Boston-Leiden, Brill editor, coll. The transformation of the Roman World, vol. 14, 2004, p. 177-253.

ARNAUD-FASETTA G., BEAULIEU J.-L. de, SUC J.-P., PROVANSAL M., WILLIAMSON D., LEVEAU P., ALOÏSI J.-C., GADEL F., GIRESSE P., EVIN J., DUZER D. (2000). Evidence for an early landuse in the Rhône delta (mediterranean France) as recorded by late Holocene fluvial paleoenvironments (1640-100 BC). Geodinamica Acta, $13: 377-389$.

ARTHUIS R. and AMBERT P. (1997). Des étangs, un petit lac, de vastes paluds, une prairie assainie : l'évolution naturelle et artificielle des cuvettes périglaciaires dans la dépression de Tras-le-Puy (Gard), durant l'Holocène. In : BURNOUF et al., 1997 : 350-364.

BADAN O., BRUN J.-P., CONGÈS G, (1995). Les bergeries romaines de la Crau d'Arles. Les origines de la transhumance en Provence. Gallia, $52: 263-310$.

BAZZANA A. (ed.) (1999). Castrum 5, Archéologie des espaces agraires méditerranéens au Moyen Âge, Casa de Velazquez, École française de Rome, Ayuntamiento de Murcia, Madrid-Rome, 496 p.

BEAULIEU J.- L. de, PONS A., et REILLE M. (1988). Histoire de la flore et de la végétation du Massif Central (France) depuis la fin de la dernière glaciation. Cahiers de micropaléontologie, N. S., 3, 4 : 5-35.

BEAULIEU J.-L. de, (1969). Analyses polliniques dans les Monts de l'Epinouse (Hérault). Pollen et Spores, 11 : 83 95.

BEAULIEU J.-L. de, (1977). Contribution pollenalytique à l'histoire tardiglaciaire et holocène de la végétation des Alpes M éridionales Françaises, Université d'Aix-Marseille III : 358 p.

BEDON R. (ed.) (1998). Suburbia. Les faubourgs en Gaule romaine et dans les régions voisines, Centre de Recherche A. Piganiol, Caesarodunum, 32, 356 p.

BELLAMY P. and HITCHNER R.-B. (1996). The villas of Vallée des Baux and the Barbegal Mill : Excavations at La Mérindole Villa and cemetery. Journal of Roman Archaeology, 9 : 154-176.

BENDER H., WOLFF H. (ed.) (1994). Ländliche Besiedlung und Lanwirschaft in den Rhein - Donau Provinze des Römischen Reiches, Passau, 2 vo., 519 p., 183 pl.

BENOIT F. (1940). L'usine de meunerie hydraulique de Barbegal. Revue Archéologique, 15, 1 : 70-71.

BENOIT F. (1959). L'Économie du littoral de la Narbonnaise. Revue d'Études Ligures, 25, Bordighera, 1959 : 87110 .

BENOIT F. (1965). Le développement de la colonie d'Arles et la centuriation de la Crau. Compte rendu à l'Académie des Inscriptions et Belles-Lettres : 156-169.

BENZI F., BERLIOCCHI L. (1999). L'histoire des plantes en Méditerranée. Art et botanique, Actes Sud / Motta, Milan, $170 \mathrm{p}$.

BÉRATO J., BOREANNI M., LEGUILLOUX M. (1990). La villa gallo-romaine des Laurons (quartier Saint-Pierre). Les Arcs sur Argens, Var. Documents d'Archéologie Méridionale, 13 : 221-247.

BERGER J.-F. (2001). Evolution des agro- et hydrosystèmes dans la région médio-rhodanienne. In : OUZOULIAS et al. 2001.

BERGER J.-F. and JUNG C. (1996). Fonction, évolution et taphonomie des parcellaires en moyenne vallée du Rhône. Un exemple intégré en archéomorphologie et en géoarchéologie. In : CHOUQUER 1996 : 95-112 
Article published in BARCELÓ M. et SIGAUT F., (eds.), The Making of Feudal Agricultures ?, Boston-Leiden, Brill editor, coll. The transformation of the Roman World, vol. 14, 2004, p. 177-253.

BERGER J.-F. et JUNG C. (1999). Developing a methodological approach to the evolution of mid-rhodanian agrosystems during historical periods. In : LEVEAU et al. 1999 : 155-168.

BERGER J.-F. (1995). Facteurs anthropiques et naturels de l'évolution des paysages romains et protomédiévaux du Bassin valdenais (Drôme). In : VAN DER LEEUW 1995 : 79-114.

BERGER J.-F. (1996). Le cadre paléogéographique des occupations du bassin valdainais (Drôme) à l'Holocène, Thèse de l'Université de Paris I, 325 p..

BERGER J.-F., BROCHIER J.-L., JUNG C., ODIOT T. (1997). Données paléogéographiques et données archéologiques dans le cadre d l'opération de sauvetage archéologique du T. G. V.- Méditerranée. In : BURNOUF et al., 1997 : 155-184.

BERGER J.-F., FAVORY F., ODIOT T., ZANNIER M.-P. (1997). Pédologie et agrologie antique dans le Tricastin central (Drôme Vaucluse), d'après les textes agronomiques et épigraphiques latins et les données géoarchéologiques. In : BURNOUF et al., 1997 : 127-154.

BERGER J.-F., MAGNIN F., THIEBAULT S., VITAL J., 2000. Emprise et déprise culturelle à l'âge du Bronze : l'exemple du bassin valdainais (Drôme) et de la moyenne vallée du Rhône, Bulletin de la société de Préhistoire française, 97-1 : 95-119.

BERGER J-F., THIÉBAULT S., Holocene fire history in South East France: Impact of climatic changes and human activities, colloque Fire and the Palaeoenvironment, Sheffield, 13-15 mars 1997.

BERTONCELLO F. and GAZENBEEK M. (1997). Dynamiques du peuplement en moyenne montagne : le massif des Maures (Var) entre le deuxième âge du Fer et la fin de l'antiquité. In : BURNOUF et al. 1997 : 601-620.

BERTONCELLO F. (1999). Le peuplement de la Basse Vallée de l'Argens et de ses marges (Var) de la fin de l'âge du Fer à la fin de l'Antiquité, Thèse de doctorat de l'Université de Provence, Aix-en-Provence, 503 p., 205 fig.

BERTRAND G. (1975). Pour une histoire écologique de la France rurale. In : DUBY 1975 : 34-113.

BETHEMONT J. (1972). Le thème de l'eau dans la vallée du Rhône. Essai de genèse d'un espace hydraulique, Le Feuillet Blanc, Saint-Etienne, 642 p.

BEUG H.-J. (1975). Changes of climate and végétation belts in the mountains of mediterranean Europe during the Holocene. Bulletin of Geology (Varsovie), $19: 101-110$.

Bilan scientifique, 22, Rhône-Alpes, 1996. Ministère de la culture, DRAC, Lyon, 208 p.

Bilan scientifique, 11, Languedoc-Roussillon 1999, Ministère de la culture, DRAC, Montpellier, 198 p.

BLANCHARD R. (1952). Les Alpes occidentales. 5 Les grandes Alpes françaises du Sud, 2 vol., Grenoble.

BLANCHEMANCHE P. (1990). Bâtisseurs de paysages, terrassements, épierrement et petite hydraulique agricole en Europe XVII ${ }^{e}$-XIX ${ }^{e}$ siècle, Maison des Sciences de l'Homme, Paris, 329 p..

BLOCH M. (1935). Avènement et conquête du moulin à eau. Annales d'histoire économique et sociale, 7 : 538-563.

BOISSINOT P. and BROCHIER J.-E. (1997). Pour une archéologie du champ. In : CHOUQUER 1997 : $35-56$.

BOISSINOT P. (1997). Archéologie des façons culturales. In : BURNOUF et al. 1997 : 85-112. 
Article published in BARCELÓ M. et SIGAUT F., (eds.), The Making of Feudal Agricultures ?, Boston-Leiden, Brill editor, coll. The transformation of the Roman World, vol. 14, 2004, p. 177-253.

BONIFAY M., CARRE M.-B., RIGOIR Y. (1998). Les fouilles de Marseille. Les mobiliers (Ier-VIIe s.), Etudes Massaliétes 5, Errance, Paris, 433 p.

BOREL J.-L., BROCHIER J.-L., DRUARD J.-C. (1996). Séquences climatiques et occupation du sol du VIII au XI ${ }^{\mathrm{e}}$ siècle dans le terroir de Colletière. In : COLARDELLE 1996 : 191-196.

BORRÉANI M., BRUN J.-P. (1998). Deux moulins hydrauliques du Haut Empire dans le département du Var (Villae des Mesclans à La Crau et des Laurons/Saint-Pierre aux Arcs-sur-Argens). Gallia, 55 : 279-326.

BOURIN-DERRUAU M. (1987). Villages médiévaux en Bas-Languedoc ; t. 1, Genèse d'une sociabilité (Xe-XIVe siècle), L'Harmattan, Paris, 339 p. ; t. 2, La démocratie au village, XIII ${ }^{e}$-XIVe siècles, L'Harmattan, Paris, 471 p.

BOYER J.-P. and EMMANUELLI F.-X. (eds.), De Provence et d'ailleurs. Mélanges offerts à N. Coulet, Provence historique, $546 \mathrm{p}$.

BOYER J.-P. (1990). Hommes et communautés du haut pays niçois médiéval. La Vésubie (XIIIe-XVe siècle), Centre d'étude médiévale, Nice, 585 p.

BRAVARD J.-P. and PRESTEAU M. (eds.) (1997). Dynamiques du paysage. Entretiens de géoarchéologie. Table ronde tenue à Lyon, les 17 et 18 novembre 1995, DARA, Lyon, $282 \mathrm{p}$.

BRENOT C. (1986). La circulation monétaire sur les sites de Lyon à la Méditerranée (IVe-VIIe siècles). In : FEVRIER $1986: 197-199$.

BRENOT C. (1996). Du monnayage impérial au monnayage mérovingien ; l'exemple d'Arles et de Marseille. In : LEPELLEY $1996: 147-160$.

BRENOT C. (1998). Fouilles de Marseille. Les mobiliers. V ${ }^{\mathrm{e}}$-VIII ${ }^{\mathrm{e}}$ siècles après J.-C.. In : BONIFAY et al. 1998 : $358-361$.

BROCHIER J.-E. (1983). Deux mille ans d'histoire du climat dans le Midi de la France. Annales (Économies, Sociétés, Civilisations), $8: 425-438$.

BROCHIER J.-E. (1991). Géoarchéologie du monde agropastoral. In : GUILAINE 1991 : 303-322.

BROCHIER J.-L. (1997). Contexte morphodynamique et habitat humain de la moyenne vallée du Rhône au cours de la préhistoire récente. In : BRAVARD and PRESTREAU : 87-102.

BRUN J.-P. and CONGÈS G. (1996). Une crise agraire en Provence au troisième siècle ? In : FICHES 1996 : 233 256.

BRUN J.-P. (1986). L'oléiculture en Provence : les huileries du département du Var, CNRS, Paris, 312 p., 224 fig. .

BRUN J.-P. (1993). L'oléiculture et la viticulture antique en Gaule, instruments et installations de production. In : AMOURETTI and BRUN 1993 : 307-341.

BRUN J.-P. (1996). La grande transhumance à l'époque romaine. À propos des recherches sur la Crau d'Arles. Anthropozoologica, $24: 31-44$.

BRUN J.-P. (1999). Le Var, 83/1 et 2, Carte archéologique de la Gaule, Paris, 984 p. 
Article published in BARCELÓ M. et SIGAUT F., (eds.), The Making of Feudal Agricultures ?, Boston-Leiden, Brill editor, coll. The transformation of the Roman World, vol. 14, 2004, p. 177-253.

BRUNAUX J.-L., MENIEL P. (1983). L'importation du bœuf à la période romaine : premières données. Revue Archéologique de Picardie, 4 : 15-20.

BRUNETON H. (1999). Evolution Holocène d'un hydrosystème nord-méditerranéen et de son environnement géomorphologique. Les plaines d'Arles à l'interface entre le massif des Alpilles et le Rhône, Doctorat de l'Université d'Aix-Marseille I,

BUFFAT L. and PETITOT H. (1998). Une activité métallurgique tardo-antique sur l'établissement de Mayran (Saint-Victor-Lacoste, Gard). In : FEUGÈRE and SERNEELS 1998 : 175-180.

BURNOUF J., BRAVARD J.-P., CHOUQUER J.-P. (eds.) (1997). La dynamique des paysages protohistoriques, antiques, médiévaux et modernes, APDCA, Sophia-Antipolis, 624 p..

BUXO I CAPDEVILA R. (1992). Cueillette et agriculture à Lattes : les ressources végétales d'après les semences et les fruits. In : PY 1992. : 45-90.

BUXO R. and PONS E. (eds.) (2000). Els productes alimentaris d'origen vegetal a l'edat del ferro de l'Europa occidental : de la produccio al consum. XXIIe colloque international pour l'étude de l'Age du Fer, Monografies del Museu d'Arqueologia de Catalunya-Girona, 18, Gérone, 413 p.

CAECALHO-QUINTELA A., MASCARENHAS J. M., CAEDOSO J.-L. (1999). Barrages romains au sud du Tage (Portugal). In : GORGES and GERMAN RODRIGUEZ MARTIN 1999 : 197-226

CARRU D., GATEAU F., LEVEAU P., RENAUD N., BERATO J., BERTONCELLO F., MEFFRE J.-C., MICHEL J.-M., MOCCI F., TRÉMENT F., VALENTIN F. (2001). Les villae en Provence aux IVe et Ve siècles : apports et limites des inventaires archéologiques. In : OUZOULIAS et al. 2001.

CASTELVI G. (1984). Les mottes castrales du Roussillon. Archéologie du Midi médiéval, 2 : 15-26.

CAUCANAS S. (1987). Les premières mentions de moulins en Roussillon. In : GRAU and POISSON 1987 : $167-174$

CAUCANAS S. (1995). Moulins et irrigation en Roussillon, du IXe au XVe siècle, CNRS, Paris, 421 p..

CHABAL L. (1997). L'anthracologie, de l'échantillonnage des charbons de bois à l'interprétation du paysage du Néolithique final à la période romaine en Bas Languedoc, Documents d'Archéologie Française, Paris, 189 p..

CHAPELOT J., FOSSIER R. (1980). Le village et la maison au Moyen Age, Hachette, Paris, 357 p..

CHOUQUER G. (ed.) (1997). Les formes du paysage, 3, L'analyse des systèmes spatiaux, Errance, Paris, 198 p, VIII pl.

CHOUQUER G. (ed.), 1996. Les formes du paysage, 2, Archéologie des parcellaires, Paris, Errance, 263 p., XVI pl.

CHOUQUER G. (2000). L'étude des paysages. Essais sur leurs formes et leur histoire. Paris, Errance, 208 p., 23 ill.

CHOUQUER, G. (1983). Localisation et extension géographique des cadastres affichés à Orange. In : CLAVELLÉVÊQUE 1983 : 275-295

CHRISTOL M., LAYRAUD J.-C., MEFFRE J.-C. (1998). Le cadastre C d'Orange : révisions épigraphiques et nouvelles données d'onomastique, Gallia, 55 : 337-343. 
Article published in BARCELÓ M. et SIGAUT F., (eds.), The Making of Feudal Agricultures ?, Boston-Leiden, Brill editor, coll. The transformation of the Roman World, vol. 14, 2004, p. 177-253.

CLAVEL-LÉVÊQUE M. (ed.) (1983 a). Cadastre et espace rural. Approches et réalités antiques, CNRS, Paris.

CLAVEL-LÉVÊQUE M. and VIGNOT A. (eds.) (1998). Cité et territoire II, Les Belles Lettres, Paris, 273 p.

CLAVEL-LÉVÊQUE M. (1995). Atlas des Cadastres de Gaule -1-. Le réseau centurié de Béziers B, Les Belles Lettres, Paris, $116 \mathrm{p}$.

CLAVEL-LEVEQUE, M. (1983 b). Pratiques impérialistes et implantations cadastrales : 223-244 (le cas de la Transalpine). Ktéma, $8: 240-247$.

COLARDELLE M. (ed.) (1996). L'homme et la nature du Moyen Age, Actes du Ve congrès international d'archéologie médiévale, Grenoble, 6-9 octobre 1993, Errance, Paris, 259 p..

COLUMEAU P. (1996). Pratiques cultuelles et spécialisation pastorale autour de l'Étang de Berre, de l'Âge du Fer à la fin de l'Antiquité. In : GATEAU 1996 : 128-136.

COLUMEAU P. (1997). La Poussaraque. Les ressources de l'élevage. Revue Archéologique de Narbonnaise, 30 : 27-30.

COLUMEAU P. (1997). Variation de la hauteur du garrot du boeuf de la fin de l'âge du Fer à l'antiquité tardive danssud-est de la Gaule. In : GARCIA and MEEKS 1997 : 153-156.

COLUMEAU P. (2000). Consommation de viande et élevage dans la vallée des Baux de l'âge du Fer au Moyen Age d'après les vestiges osseux. In : LEVEAU and SAQUET $2000:$ 347-357.

COMET G. (1999). Moulins de Provence et d'ailleurs. Historiographie, méthode et idéologie chez les historiens. In : BOYER and EMMANUELLI 1999 : 159-168.

CONGÈS G. (1997). Bergerie et transhumance dans la Crau antique : innovation et adaptation. In : GARCIA and MEEKS 1997 : 149-152.

COSTE P., COULET N. (1994). Que sait-on des origines de la transhumance en Provence ? In : DUCLOS J.-C. and PITTE A., L'homme et le mouton dans l'espace de la transhumance, Glénat, Grenoble : 65-70.

COULET N. (1993). Une opération de drainage en Basse Provence orientale au XVe siècle. Rives nord méditerranéennes, 8, GIS "Cultures et Civilisations Méridionales (XIe-XXe) (Université de Provence) : 58-61.

DARNAS I. (1998). Un castrum artisanal : Calberte en Gévaudan (XIIe-XIVe siècle). In : FELLER et al. 1998 : 335-348.

DAUZAT M. (1983). Les mottes castrales du Lauragais : notes préliminaires, Le Lauragais. Histoire et archéologie.

DAVASSE B., GALOP D., RENDU C. (1997). Paysages du Néolithique à nos jours dans les Pyrénées de l'Est d'après l'écologie historique et l'archéologie pastorale. In : BURNOUF et al. 1997 : 577-599.

DEMIANS D'ARCHIMBAUD G. (ed.) (1994). L'oppidum de Saint-Blaise (Bouches-du-Rhône) du Ve au VIIIe s., Documents d'Archéologie Française 45, Paris, 264 p., 172 ill..

DION R. (1959). Histoire de la vigne et du vin en France. Des origines au XIXe siècle, Paris,

DUBY G. (ed.) (1975). Histoire de la France rurale. T. 1 La formation des campagnes françaises des origines au XIVe siècle, Seuil, Paris, 624 p. 
Article published in BARCELÓ M. et SIGAUT F., (eds.), The Making of Feudal Agricultures ?, Boston-Leiden, Brill editor, coll. The transformation of the Roman World, vol. 14, 2004, p. 177-253.

DUBY G. 1975. Avant-propos. In : DUBY 1975 : 19-75.

DUBY G. (1962). L'économie rurale et la vie des campagnes dans l'Occident médiéval (France, Angleterre, Empire, IXe-XIVe siècles), t. 1, Aubier, Paris, 285 p..

DURAND A. (1998). Les paysages médiévaux du Languedoc, Toulouse, Presses universitaires du Mirail, 491 p..

DURAND A. (in press). Les moulins carolingiens du Languedoc de la fin du VIIIe siècle au milieu du XIe siècle. In : MOUSNIER, in press.

DURAND A., FOREST V., GARDEISEN A., RUAS M.-P. (1997). Approches bioarchéologiques de l'habitat castral languedocien : huit sites de la bordure méridionale du Massif central. Histoire et Sociétés rurales, $8: 11$ 32 .

DURAND-DASTÈS F, FAVORY F., FICHES J.-L., MATHIAN H., PUMAIN D., RAYNAUD C., SANDERS L., VAN DER LEEUW S. (1998). Des oppida aux métropoles. Archéologues et géographes en vallée du Rhône, Anthropos, Paris, 280 p.

FABRE G., BOURIN M., CAILLE J., DEBORD A. (ed.) (1996). Morphogenèse du village médiéval (IXe-XIIe siècles). In : Actes de la table ronde de Montpellier (22-23 février 1993), Inventaire général, Cahiers du patrimoine, Montpellier, $299 \mathrm{p}$.

FARIZIER M. (1980). Recherches sur les macroflores des tufs quaternaires du Sud de la France. DESS., Ecole pratique des Hautes études, Université des Sciences et Techniques du Languedoc-Montpellier II, 326 p. et XXVII planches.

FAVORY F. and FICHES J.-L. (eds.) (1994). Les campagnes de la France méditerranéenne dans l'Antiquité et le haut Moyen Âge. Études microrégionales, Paris, Documents d'Archéologie Française 42, 339 p., 205 ill.

FAVORY F. (1988). Le site de Lattes et son environnement (France Hérault), d'après les images aériennes et les documents planimétriques. Lattara $1: 15-56$.

FAVORY F. (1996). Morphologie agraire isocline avec une limitation romaine. Acquis et problèmes. In : CHOUQUER 1996 : 193-200, pl. VI-IX.

FELLER L., MANE P., PIPONNIER F. (eds.) (1998). Le village médiéval et son environnement. Mélanges offerts à J.-M. Pesez, Publications de la Sorbonne, Paris, 683 p.

FEUGÈRE M. and SERNEELS V. (eds.) (1998). Recherches sur l'économie du fer en Méditerranée nord occidentale, (Monographie Instrumentum, 4), Monique Mergoil, Montagnac, 263 p..

FÉVRIER P.- A. (1978). Problème de l'habitat du Midi méditerranéen à la fin de l'Antiquité et dans le Haut Moyen Age. Jahrbuch des römisch-germanischen Zentralmuseums Mainz : 208-247.

FÉVRIER P.-A. (ed.), 1986. Premiers temps chrétiens en Gaule méridionale. Antiquité tardive et haut Moyen Age IIIe-VIIle siècles, Archéologie médiévale en Rhône-Alpes, Association Lyonnaise de Sauvegarde des Sites Archéologiques Médiévaux, Lyon, 210 p.

FEVRIER P.-A. (1981). Villes et campagnes des Gaules sous l'Empire. Ktéma, nº 6 : 359-372.

FICHES J.-L. (ed.) (1989). L'oppidum d'Ambrussum et son territoire, CNRS, Paris, 286 p. 
Article published in BARCELÓ M. et SIGAUT F., (eds.), The Making of Feudal Agricultures ?, Boston-Leiden, Brill editor, coll. The transformation of the Roman World, vol. 14, 2004, p. 177-253.

FICHES J.-L. (ed.) (1996). Le IIIe siècle en Gaule Narbonnaise. Données régionales sur la crise de l'Empire, APDCA, Juan-les-Pins, 404 p..

FICHES J.-L. (ed.), BÉRATO J., BRENTCHALOF D., CHOUQUER G., DUBAR M., GAZENBEEK M., LATOUR J., ROGERS G. B. (1995). Habitats de l'Age du Fer et structures agraires d'époque romaine aux Escaravatiers (Puget-sur-Argens, Var). Gallia, 52 : 205-261.

FICHES J.-L. and VEYRAC A. (eds.) (1996). Nîmes 30/1. Maison des Sciences de l'Homme, Paris, 634 p., XXXI pl..

FINLEY, M. I. (ed.) (1976), Studies in Roman Property, Cambridge.

FIXOT M. and ZADORA RIO E. (eds.) (1994). L'environnement des églises et la topographie religieuse des campagnes médiévales, Documents d'Archéologie Française 46, Paris, 184 p., 90 ill.

FIXOT M. (1975). La motte et l'habitat fortifié en Provence médiévale, Château-Gaillard. Etudes de castellologie médiévale, Actes du colloque international tenu à Blois 2-7 septembre 1974,7 , C.N.R.S.Université de Caen, Caen : 67-93.

FIXOT M. (1994). L'église médiévale dans l'espace rural provençal d'après les fouilles récentes. In : FIXOT and ZADORA-RIO 1994 : 36-47.

Flaran (1990) : La croissance agricole du haut Moyen Age. Chronologie, modalités, Géographie, Actes des 10e Journées internationales d'histoire médiévale et moderne tenues au Centre culturel de l'abbaye de Flaran des 9-11 septembre 1988, Comité départemental du Tourisme du Gers, Auch, 1990, 205 p.

Flaran (1992): Plantes et cultures nouvelles en Europe occidentale, au Moyen Age et à l'époque moderne, Actes des 12e Journées internationales d'histoire médiévale et moderne tenues au Centre culturel de l'abbaye de Flaran les 11-13 septembre 1990, Valence-sur-Baïse, Centre culturel de l'abbaye de Flaran, 155 p.

FOREST V. and RODET-BELARBI I. (1997). Augmentation du format des bovins en Gaule romaine : problèmes méthodologiques et innovation technique. In : GARCIA and MEEKS, 1997 : 166-171.

FOREST V. and RODET-BELARBI I. (1998). Ostéométrie du métatarse des bovins en Gaule de la Conquête romaine à l'Antiquité tardive. Revue Méd. Vétérinaire, 149, 11 : 1033-1056.

GALOP D. (1998). La forêt, l'homme et le troupeau dans les Pyrénées. 6000 ans d'histoire de l'environnement entre Garonne et Méditerranée. Contribution palynologique, Géode,Toulouse, 285 p.

GARCIA D. and MEEKS D. (eds.) (1997). Techniques et économie antiques et médiévales. Le temps de l'innovation, Errance, Paris, 239 p.

GARCIA D. (1992). Les éléments de pressoirs de Lattes et l'oléiculture antique en Languedoc. In : PY 1992 : 237258.

GARMY P. and MONTEIL M. (eds.) (2000), Le quartier antique des Bénédictins à Nîmes (Gard), Documents d'Archéologie Française 81, Paris, 282 p, 236 fig.

GARNIER B., GARNOTEL A., MERCIER C., RAYNAUD C. (1995). De la ferme au village : Dassargues du Ve au XIIe siècle (Lunel, Hérault). Archéologie du Midi Médiéval, 13 : 1-78.

GASCOU J. and LEVEAU P. (1996). Un témoignage sur l'économie domaniale près d'Arles au début de l'Empire? Un membre d'un collège de fabri à Barbegal (Fontvieille, Bouches-du-Rhône). Ktéma, 21 : 237-250. 
Article published in BARCELÓ M. et SIGAUT F., (eds.), The Making of Feudal Agricultures ?, Boston-Leiden, Brill editor, coll. The transformation of the Roman World, vol. 14, 2004, p. 177-253.

GATEAU F. and GAZENBEEK (eds.) (1999). Les Alpilles, 13/2, Carte Archéologique de la Gaule, Maison des Sciences de l'Homme, Paris, $464 \mathrm{p}$.

GATEAU F. (1996). Bouches-du-Rhône, 13, Carte Archéologique des communes des rives de l'Étang de Berre, Carte Archéologique de la Gaule, Éditions de la Maison des Sciences de l’Homme, Paris, 380 p.

GATEAU F. (1997). L'établissement rural de la Pousarague, Revue Archéologique de Narbonnaise, 30 : 5-31.

GAZENBEECK, M. (1998). Prospections systématiques autour de Glanum (Bouches-du-Rhône) : l'extension de l'agglomération. In : BEDON 1998 : 83-103

GINOUVÈZ O., JANIN T., VIDAL L., POUPET P. (1990). Paléosols et structures agraires enfuies : quelques exemples d'approche du paysage rural. In : Archéologie et espace, $1990: 383-418$.

GINOUVEZ O., POMARÈDES H., FEUGÈRE M., 1998. Le travail du fer dans la villa de la Domergue à Sauvian (Hérault). In : FEUGÈRE and SERNEELS $1998:$ 181-185.

GINOUVEZ, O. (1993). Des maisons excavées à Narbonne autour de l'an Mil. Archéologie du Midi Médiéval, $11: 53-68$.

GORGES J.-G. and GERMAN RODRIGUEZ MARTIN F (eds.) (1999). Economie et territoire en Lusitanie romaine, 65, Casa de Velazquez, Madrid, 555 p.

GOURY D. (1997). L'oppidum du Camp de César à Laudun (Gard) : premières acquisitions de la recherche 1990-1994. Revue Archéologique de Narbonnaise, 30 : 125-172.

GRAU M. and POISSON O. (eds.) (1987). Etudes roussillonnaises offertes à Pierre Ponsich. Mélanges d'archéologie, d'histoire et d'histoire de l'art du Roussillon et de la Cerdagne = Estudis rossellonesos dedicata a en Pere Ponsich : miscellània d'arqueologia, historia de l'art del Rosselo i de la Cerdanya, Le Publicateur, Perpignan, $558 \mathrm{p}$.

GROS P. (1995). Hercule à Glanum, sanctuaires de transhumance et développement " urbain ". Gallia, 52 : 311 331.

GUILAINE J. (ed.) (1991). Pour une archéologie agraire, Colin, Paris, 576 p.

GUILAINE J. (ed.) (1995). Temps et espace dans le bassin de l'Aude du néolithique à l'Âge du Fer, Centre d'Anthropologie des Sociétés rurales, Toulouse, $442 \mathrm{p}$.

IZARD V. (1999). Les montagnes du fer. Eco-histoire de la métallurgie et des forêts dans les Pyrénées méditerranéennes (de l'Antiquité à nos jours). Pour une histoire de l'environnement, Thèse de l'université de Toulouse II-le-Mirail, t.I, 560 p., t.II, 192 p.

JALUT G. (1991). Le pollen, traducteur du paysage agraire. In : GUILAINE 1991 : 345-368.

JALUT G., ESTEBAN AMAT A., BONNET L ., FONTUGNE M., GAUQUELIN T., (2000). Holocene climatic changes in the Western Mediterranean, from south-east France to south-est Spain. Palaeogeography, Palaeoclimatology, Paleoecology, $160: 255-290$.

JALUT G., ESTEBAN AMAT A., RIERA MORA S., FONTUGNE M., MOOK R., BONNET L., GAUQUELIN T. (1997). Holocene climatic changes in the western Mediterranean : installations of the Mediterranean climate. Compte Rendu à l'Académie des Sciences de Paris, Sciences de la terre et des planètes, 325 : 327-334. 
Article published in BARCELÓ M. et SIGAUT F., (eds.), The Making of Feudal Agricultures ?, Boston-Leiden, Brill editor, coll. The transformation of the Roman World, vol. 14, 2004, p. 177-253.

JORDA M. and MOCCI F. (1997). Sites protohistoriques et gallo-romains du massif de Sainte-Victoire dans leur contexte morphodynamique. In : BURNOUF et al. $1997: 212-229$.

JOURDAN L. (1976). La faune du site gallo-romain et paléochrétien de La Bourse à Marseille, CNRS, Paris.

JOURNOT F. (1990). Archéologie des châteaux médiévaux de la montagne héraultaise (bassin de l'Orb et de la Lergue), Xe-XIVe siècle, thèse d'archéologie et d'histoire de l'art de l'Université de Rennes II, t. I, 313 p., t. II, 283, t. III, $302 \mathrm{p}$.

KOTARBA J., ALESSANDRI P., COMPAN M., PEZIN A., POMAREDES H. (1987). Arles-13, Augery de Corrèges- Sauvetage programmé, rapport de fouille, Service régional de l'archéologie du Languedoc-Roussillon.

KRAUSS-MARGUET I. (1981). Analyse anthracologique du gisement postglaciaire de la Poujade (Millau, Aveyron). Paléobiologie Continentale, 12, 1, 9:93-110.

LAFFONT P.-Y. (1998). Châteaux, pouvoirs et habitats en Vivarais, Xe-XIIIe siècles, Thèse Université de Lyon II, vol I $372 \mathrm{p}$. and vol. II, $344 \mathrm{p}$.

LAUBENHEIMER F. (1985). La production des amphores en Gaule narbonnaise, Belles Lettres, Paris, 426 p.

LAVAGNE H. (1981). Les nouvelles mosaïques de la villa gallo-romaine de Loupian (Hérault). Revue Archéologique de Narbonnaise, 14 : 173-203.

LAVAL H. and MALLÉA M. (1993). Analyse sporopollinique de sédiments médiévaux à Augery, Camargue. In : LEVEAU and PROVANSAL 1993 : 387-390.

LAVAL H. and MEDUS J. (1994).- Une séquence pollinique subboréal-subatlantique dans la vallée des Baux : changements de végétation, climatiques et anthropogéniques de l'âge du Bronze à celui du Fer en Provence. Archives Sciences de Genève, 47, 2 : 83-94.

LAVAL H., MEDUS J., ROUX M. (1991). Palynological and sedimentological records of Holocene human impact for the Etang de Berre, southeastern France. The Holocene, 1-3 : 269-272.

LEENHARDT M., RAYNAUD C., SCHNEIDER L. (eds.) (1993). Céramiques languedociennes du haut Moyen Age (VII-XIe s.). Etudes micro-régionales et essai de synthèse. Archéologie du Midi Médiéval, 11 : 111-228.

LEGUILLOUX M. (1989). La faune des villae gallo-romaines dans le Var : aspects économiques et sociaux. Revue Archéologique de Narbonnaise, 22 : 311-322.

LEGUILLOUX M. (1998). La faune tardive du port de Marseille (Ve.-VIIe s. ap. J.-C.) d'après les fouilles de la Bourse (1980-1981). Revue Archéologique de Narbonnaise, 31 : 233-253.

LEGUILLOUX M., L'acquisition des techniques d'élevage en Narbonnaise orientale. In : GARCIA and MEEKS $1997: 172-174$.

LEPELLEY C. (1996). La fin de la cité antique et le début de la cité médiévale de la fin du IIIe siècle à l'avènement de Charlemagne. Actes du colloque (Paris, 1-3 avril 1993), Edupuglia, Bari : 147-160.

LEPETZ S. (1997). L'amélioration des espèces animales domestiques à la période romaine en France du Nord. In : GARCIA and MEEKS $1997: 157-165$;

LEROY S. (1995). Analyse palynologique du forage Peyriac-Sud. In : GUILAINE 1995 : 369-390. 
Article published in BARCELÓ M. et SIGAUT F., (eds.), The Making of Feudal Agricultures ?, Boston-Leiden, Brill editor, coll. The transformation of the Roman World, vol. 14, 2004, p. 177-253.

Les étangs à l'époque médiévale d'Aigues-Mortes à Maguelone, (1986). Catalogue de l'exposition, Musée archéologique, Lattes, 173 p.

LEVEAU P. and PROVANSAL M. (1993). Archéologie et environnement : de la Sainte-Victoire aux Alpilles, Publications de l'université de Provence, Aix-en-Provence, 551 p.

LEVEAU P. and SAQUET J.-P. (eds.), 2000. Milieux et société dans la vallée des Baux, Revue Archéologique de Narbonnaise, supl. 31, Montpellier, 2000, 390 p.

LEVEAU P. (1993). Sociétés antiques et écologie des milieux montagnards et palustres. (La construction des paysages méditerranéens). In : LEVEAU and PROVANSAL, 1993.

LEVEAU P. (1996). The Barbegal waters mille in its environment: and the economic and social history of antiquity. Journal of Roman Archaeology, 9 : 137-153.

LEVEAU P. (1997). L'archéologie des paysages et les époques historiques : les grands aménagements agraires et leur "signature" dans le paysage (anthropisation des milieux et complexité des sociétés). In: MORNET and MORENZONI 1997 : 71-84.

LEVEAU P. (1999). The Integration of archeological, historical and environmental data : the example of the "Valléedes-Baux" (Bouches-du-Rhône, France). In : LEVEAU et al. 1999 : 193-206.

LEVEAU P. (2000). L’archéologie des paysages aux époques historiques. Annales, Histoire, Sciences sociales, 3 : $555-582$.

LEVEAU P., HEINZ C., LAVAL H., MARINVAL P., MÉDUS J. (1991). Les origines de l'oléiculture en Gaule du Sud. Données historiques, archéologiques et botaniques. Revue d'Archéométrie 15 : 83-94.

LEVEAU P., PROVANSAL M., BRUNETON H., PALET-MARTINEZ J.-M., POUPET P. WALSH K., 2001 (in press). La crise environnementale de la fin de l'Antiquité et du haut Moyen Âge : définition d'un modèle et retour au milieu réel. In : MAGNY and RICHARD 2001 (in press).

LEVEAU P., TRÉMENT F., WALSH K. and BARKER G. (ed.), 1999. Environmental Reconstruction in Mediterranean Landscape Archaeology, Oxbow Book, Oxford, 210 p.

LIOU B. and MOREL M. (1977). L'orge des Cavares. Revue Archéologique de Narbonnaise, 10 : 189-197.

LORREN C. and PÉRIN P. (eds.), 1995. L'habitat rural du haut Moyen Age (France, Pays-Bas, Danemark, Grande-Bretagne). Actes des XIVe journées d'archéologie mérovingienne, Paris, 1993, Musée des Antiquités de Seine Maritime, Rouen, 237 p.

MACDERMOTT F., FRISIA S., HUANG Y., LONGINELLI A., SPIRO B., HEATON T., HAWKESWORTH C., BORSATO A., KEPPENS E., FAIRCHILD I., VAN DER BORG K., VERHEYDEN S., SELMO E. (1999). Holocene climate variability in Europe : evidence from $\delta 18 \mathrm{O}$, textural and extension-rate variation in three speleothems. Quaternary Science Review, t. 18 : 1021-1038.

MAGNY M. and RICHARD H. (eds.), 2001 (in press). Équilibres et rupture dans les écosystèmes durant les 20 derniers millénaires : durabilité et mutation.

MAGNY M. and RICHARD H. (1992). Le climat à la fin de l'Age du Fer et dans l'Antiquité (500 BC - 500 AD). Méthodes d'approche et résultats. Les Nouvelles de l'Archéologie, 50 p.

MAGNY M. (1992). Les fluctuations des lacs jurassiens et subalpins. In : MAGNY and RICHARD 1992 : $32-$ 
Article published in BARCELÓ M. et SIGAUT F., (eds.), The Making of Feudal Agricultures ?, Boston-Leiden, Brill editor, coll. The transformation of the Roman World, vol. 14, 2004, p. 177-253.

36.

MARINVAL M.-C. and THIEBAULT S. (1996). Faune et flore témoins de l'exploitation du territoire rural. In : COLLARDELLE $1996: 11-19$.

MARINVAL P. (1997). Vigne sauvage et vigne cultivée dans le bassin méditerranéen. Émergence de la viticulture. Contribution archéo-botanique. In : L'histoire du vin. Une histoire de rites, Paris, 137-172.

MARINVAL P. (2000). Agriculture et structuration du paysage agricole à Marseille grecque et dans les sociétés indigènes aux premier et second Ages du Fer. Pallas, 52 :

MAUFRAS O., FABRE L., COLOMER G., SEDRAOUI Z. (1998). Une forge tardive (IV-Ve s.) sur le site de La Ramière (Roquemaure, Gard). In : FEUGËRE and SERNEELS 1998 : 210-221.

MAUNÉ S. and FEUGÈRE M. (1999). La villa gallo-romaine de Lieussac (Montagnac, Hérault, France) au VIe s. de notre ère. Archäologisches Korrespondanzblatt, 29 : 377-394.

MAUNÉ S. (1998). Les campagnes de la cité de Béziers dans l'Antiquité (partie nord-orientale) (Ile s. av. J.-C., VIe s. ap. J.-C. ), Montagnac, Monique Mergoil, 532 p..

MAUNÉ S. (1999). Paulhan. Vareilles. In : Bilan scientifique Languedoc-Roussillon 1999 : 142-144.

MAUNÉ S., SANCHEZ C., FOREST V., CHABAL L., BOUCHETTE A. (1998). L'établissement rural des JurièresBasses à Puissalicon (Hérault) Ier s.-VIe s. ap. J.-C., Contribution à l'histoire des campagnes de la cité de Béziers dans l'Antiquité. In : CLAVEL-LÉVÊQUE and VIGNOT 1998 : 73-121.

MAZOYER M. and ROUDART L. (1997). Histoire des agricultures du monde du néolithique à la crise contemporaine, Le Seuil, Paris, $564 \mathrm{p}$.

MERCIER C. and RAYNAUD C. (1995). L'habitat rural en Gaule Méditerranéenne aux VIe-VIIe s.. Approche régionale et étude de cas. In : LORREN and PERRIN, 1995 : 194-206.

METAILIE J.-P. (1981). Le feu pastoral dans les Pyrénées centrales (Barousses, Oueil, Larboust), C N R S, Paris, 294 p. .

Mines et mineurs en Languedoc-Roussillon et régions voisines de l'Antiquité à nos jours, (1976). Actes du XLIXe congrès de la fédération historique du Languedoc et du Roussillon organisé à Alès les 22 et 23 mai 1976, La Fédération, Montpellier, $334 \mathrm{p}$.

MONTEIL M., BARBERAN S., PISCORZ M. and VIDAL, BEL V., SAUVAGE L. (1999). Culture de la vigne et traces de plantation des IIe-Ier s. av. J.-C. dans la proche campagne de Nîmes (Gard, France). Revue Archéologique de Narbonnaise, $32: 67-124$.

MORNET E. and MORENZONI F. (eds.) (1997). Milieux naturels, espaces sociaux. Études offertes à Robert Delort, Paris, Publications de la Sorbonne, 161 p.

MOUSNIER M. (ed.) (2001). L'artisan au village dans l'Europe médiévale et moderne, Actes des $19^{\mathrm{e}}$ journées internationales d'histoire médiévale et moderne tenues à Flaran (septembre 1997), Presses universitaire du Mirail, Toulouse. 
Article published in BARCELÓ M. et SIGAUT F., (eds.), The Making of Feudal Agricultures ?, Boston-Leiden, Brill editor, coll. The transformation of the Roman World, vol. 14, 2004, p. 177-253.

MOUSNIER M. (ed.) (in press). Moulins et meuniers dans les campagnes européennes (IXe-XVIIIe siècle), Actes des journées internationales dhistoire médiévale et moderne tenues à Flaran (3-5 septembre 1999), Presses universitaires du Mirail, Toulouse.

NEBOIT R. (1991). L'homme et l'érosion. L'érosion des sols dans le monde, Publications de la Faculté des Lettres, Clermont-Ferrand, 269 p..

ODIOT Th. (1996). Donzère. Le Mollard (26). In : Formes de l'habitat rural en Gaule narbonnaise, n. 3, Sophia Antipolis, $25 \mathrm{p}$.

OUZOULIAS P., PELLECUER C. RAYNAUD C. (2001). Les campagnes de la Gaule à la fin de l'Antiquité. Actes du colloque de Montpellier, APDCA, Antibes,

PALET J.-M. (1997). Estudi territorial del Pla de Barcelona. Estructuracié i evolucié del territori entre l'època iberoromana i l'altmedieval. Segles II-I a C-X-XI dC, Barcelona, $218 \mathrm{p}$.

PALS J.-P. (ed.) (1992). Festschrift for Professor W. Van Zeist, Review of Paleobotany and Palynology, 73.

PARODI A., RAYNAUD C., ROGER J. M. (1987). La Vaunage du IIIe siècle au milieu du XIIe siècle. Habitat et occupation du sol. Archéologie du Midi Médiéval, 4 : 3-59.

PATZELT G. (1994). Die klimatischen Verhaltnisse im südlichen Mitteleuropa zur Römerzeit. In : BENDER and WOLFF 1994 : 7-20

PELLECUER C. (1998). Le travail du fer dans la villa des Près-Bas à Loupian (Hérault). In : FEUGÈRE and SERNEELS $1998: 166-174$.

PELLECUER Ch. (1996). Villa et domaine. In : FICHES 1996 : 277-291.

PELLECUER Ch. (2000). La villa des Prés-Bas (Loupian, Hérault) dans son environnement. Contkibution à l'étude des villae et de l'économie domaniale en Narbonnaise, Thèse de Doctorat, Université de Provence, 565 p.

PESEZ J.-M. (1991). Outils et techniques agricoles du monde médiéval. In : GUILAINE 1991 : 131-164.

PIGANIOL A. (1962). Les documents cadastraux de la colonie romaine d'Orange, Gallia suppl. 16, CNRS, Paris, 434 p., 36 fig., 47 pl.

PLANCHAIS N. (1982). Palynologie lagunaire de l'étang de Mauguio. Paléoenvironnement végétal et évolution anthropique. Pollen et Spores, XXIV : 93-118.

PLANCHAIS N. (1985). Analyses polliniques du remplissage holocène de la lagune de Canet (plaine du Roussillon, département des Pyrénées Orientales). Ecologia mediterranea, 11, fasc. 1 : 117-127.

PONS A. and QUEZEL P. (1998). À propos de la mise en place du climat méditerranéen. Compte Rendu à l'Académie des Sciences, Paris, Sciences de la Terre et des planètes, 327, série IIa : 755-760.

POUPET P. (1989). La société agricole et son rapport avec l'espace. In : FICHES 1989 : 263-266.

POUPET P. (1994). Quelques éléments pour l'histoire de l'espace rural et de l'agriculture antique en Tricastin : le quartier des Hauts-Palus, Suze-la-Rousse (Drôme). In : FAVORY and FICHES 1994 : 108-116.

POUPET P. (2000). L'anthropisation des pentes du mont Cavalier : archéologie agraire en milieu urbain. In : GARMY and MONTEIL $2000: 27-40$. 
Article published in BARCELÓ M. et SIGAUT F., (eds.), The Making of Feudal Agricultures ?, Boston-Leiden, Brill editor, coll. The transformation of the Roman World, vol. 14, 2004, p. 177-253.

PROVANSAL M., BERGER J.-F., BRAVARD J.-P., SALVADOR P.-G., ARNAUD-FASSETTA G., BRUNETON H., VÉROT-BOURRELY A. (1999). Le régime du Rhône et les mutations des environnements fluviaux du lac de Genève à la mer. Gallia 56 : 13-32.

PROVANSAL, M. (1996). The part of climate in morphogenesis from the Bronze Age in Provence, southearn France. The Holocene, 5, $3: 348-353$.

PROVOST M. (1984). L'homme et les fluctuations climatiques en Gaule dans la deuxième moitié du II ${ }^{\mathrm{e}}$ siècle après J.-C.. Revue Archéologique, 1 : 71-78.

PUERTAS O. (1998). Palynologie dans le delta du Lez. Contribution à l'histoire du paysage de Lattes. Lattara 11, Lattes, $181 \mathrm{p}$.

PUERTAS O. (2000). Spatialisation des activités agricoles dans le delta du Lez à partir de l'analyse pollinique. In : BUXO and PONS $2000: 43-49$.

PY M. (ed.), 1992. Recherches sur l'économie vivrière des Lattarenses. Lattara 5, Lattes, 343 p.

QUILICI GIGLI S. (1989). Paesaggi storici dell'agro falisco. I prata di Corchiano. Opuscola Romana, 17 : 123-135.

QUILICI L. and QUILICI-GIGLI S. (ed.) (1995). Interventi di bonifica agraria nell'Italia romana, Atlante tematico di topografia antica, 4, L’Erma di Bretschneider, Roma, 248 p.

QUILICI-GIGLI S. (1995). Bonifica agraria e difesa dei territori montani. Alcuni interventi nella bassa Sabina. In : QUILICI and QUILICI-GIGLI $1995: 129-156$

RAYNAUD C. (ed.), BRIEN-POITEVIN F., CHABAL L., COLUMEAU P., DIOT M.-F., DURANT A., MANNIEZ Y., RUAS M-P. (1990). Le village gallo-romain et médiéval de Lunel Viel (Hérault), La fouille du quartier ouest (1981-1983). Annales littéraires de l'université de Besançon, Besançon, 353 p.

RAYNAUD C. and SCHNEIDER L. (2000). L'habitat en marge. Grottes et sites perchés en Languedoc et en Provence. In : OUZOULIAS et al. 2001.

RAYNAUD C. (1996). Les Campagnes rhodaniennes : quelle crise ? In : FICHES $1996: 189-212$.

RAYNAUD C., 1998. L'activité métallurgique à Lunel-Vieil (Hérault) du Ier au XIe s.. In : FEUGÈRE and SERNEELS 1998: 155-165.

REILLE M. (1991). L'origine de la station de pin à crochets de la tourbière de Pinet (Aude) et de quelques stations isolées de cet arbre dans les Vosges et le Jura. Bulletin de la Société Botanique de France, 138, 2 : 123-48.

RIERA I MORA S. (1995). Evolucio del paisatge vegetal holocè al Pla de Barcelona a partir de les dades polliniques, Barcelone, Universitat de Barcelona. Colleccio de Tesis Doctorals. Microfixades.

RIERA I MORA S. (2000). Anthropisation du paysage végétal dans la vallée des Baux : premiers résultats de prélèvements paléo-polliniques effectués durant l'opération "Artère du Midi. In : LEVEAU and SAQUET 2000 : 359-372.

RIVET A. L. F. (1988). Gallia Narbonensis, Batsford, London, 370 p..

RIVET L. (1996). Saint-Julien-lès-Martigues. In : GATEAU 1996 : 249-254. 
Article published in BARCELÓ M. et SIGAUT F., (eds.), The Making of Feudal Agricultures ?, Boston-Leiden, Brill editor, coll. The transformation of the Roman World, vol. 14, 2004, p. 177-253.

ROTH-CONGÈS A. (1997). La fortune éphémère de Glanum : du religieux à l'économique (à propos d'un article récent). Gallia, $54: 157-202$.

ROYET R. (1996). Saint-Martin de Jalionas. In : Bilan scientifique Rhône-Alpes, 1996 : 116.

RUAS M. P. and MARINVAL P. (1991). Alimentation végétale et agriculture d'après les semences archéologiques (de 9000 avant J.-C. au XIV ${ }^{\mathrm{e}}$ siècle). In : GUILAINE 1991 : 409-439.

RUAS M.-P. (1992). Les plantes exploitées en France d'après les semences archéologiques. In : Flaran 1992 : 9-35.

RUAS M.-P. (1992). The archeobotanical record of cultived and collected plants of economic importance from medieval sites in France. In : PALS 1992 : 301-314.

RUAS M.-P. (1996). Eléments pour une histoire de la fructiculture en France : données archéo-botaniques de l'Antiquité au XVIIe siècle. In : COLARDELLE 1996 : 92-105.

RUAS M.-P. (1999). Semences archéologiques, miroir des productions agraires en France méridionale du VIe au XVIe siècle. In : BAZZANA 1999 : 301-316.

SAPIN J. (1981). Jalons géographiques pour l'histoire d'un milieu de vie antique : "La Vaunage ". Documents d'archéologie méridionale, 4 : 169-178.

SCLAFERT T. (1959). Cultures en Haute Provence : déboisement et pâturages au Moyen Age, Editions de la Maison des Sciences de l'Homme, Paris, 271 p.

SERRES F. (1979). Résultats dendroclimatiques pour les Alpes méridionales françaises. In : Evolution des atmosphères planétaire et climatologiques de la Terre, colloque international, CNE S : 381-386.

SIGAUT F. (1975). L'agriculture et le feu, Editions de la Maison des Sciences de l'Homme Paris, 320 p.

STOUFF L. (1988). L'olivier et l'huile d'olive en Provence aux derniers siècles du Moyen Age. Provence historique, $38: 181-191$.

STOUFF L. (1993). La lutte contre les eaux dans les pays du Bas-Rhône (XII ${ }^{\mathrm{e}}-\mathrm{XV}^{\mathrm{e}}$ siècles). L'exemple du pays d'Arles. Méditerranée, 3/4 : 57-68.

TERRAL J.-F. (1997). Le début de la domestication de l'olivier (Olea europea L.) en Méditerranée nord-occidentale, mise en évidence par l'analyse morphométrique appliquée à du matériel anthracologique. Compte Rendu de l'Académie des Sciences Paris, 324, série IIa : 417-425.

THOMAS A. and WILSON A. (1994). Water supply for Roman farms in Latium and South Etruria. Papers of the British School at Rome (Macmillan London), 99 : 157-158.

TRÉMENT F. (ed.), BERATO J., BERGER J.-F., BERTONCELLO F., BORRÉANI M., GATEAU F., GAZENBEEK M., LANDURÉE C., MOCCI F., MEFFRE J.-C., ODIOT T., PASQUALINI M. (2001). Le peuplement rural de la Provence, de la basse et moyenne vallée du Rhône aux IVe et Ve s.. In : OUZOULIAS et al. 2001.

TRÉMENT F. (1999a). Archéologie d'un paysage. Les étangs de Saint-Blaise, Documents d'Archéologie Française, Editions de la Maison des Sciences de l'Homme, Paris, 314 p.. 
Article published in BARCELÓ M. et SIGAUT F., (eds.), The Making of Feudal Agricultures ?, Boston-Leiden, Brill editor, coll. The transformation of the Roman World, vol. 14, 2004, p. 177-253.

TRÉMENT F. (1999b). The integration of historical, archaeological and paleoenvironmental data at the regional scale : the Étang de Berre, southern France. In : LEVEAU et al. (eds) 1999 : 193-205.

TRIAT-LAVAL H. (1978). Contribution pollenanalytique à l'histoire tardi- et postglaciaire de la végétation de la basse vallée du Rhône. Thèse, Université Aix-Marseille III, 3, 343 p.

TRIAT-LAVAL H. (1982). Pollenanalyse de sédiments quaternaires récents du pourtour de l'Etang de Berre. Ecologia Mediterranea, VIII, 4 : 97-115.

VAN DER LEEUW S. (ed.) (1995). L'homme et la dégradation de l'environnement, XVe Rencontres internationales d'Archéologie et d'Histoire d'Antibes, APDCA, Sophia Antipolis, $514 \mathrm{p}$.

VAN OSSEL P. and OUZOULIAS P. (2000). Rural settlement economy in Northern Gaul in the Late Empire : a overview and assessment. Journal of Roman Archaeology, 13 : 134-160.

VAN OSSEL P. (1992). Etablissements ruraux de l'Antiquité tardive dans le Nord de la Gaule, CNRS, Paris, 470 p..

VERNET J.-L. (1973). Étude sur l'histoire de la végétation de la France au Quaternaire d'après les charbons de bois principalement. Paléobiologie continentale, 4, 1 Montpellier, 90 p, 13 p..

VERNET J.-L., PACHIAUDI C., BAZILE F., CHABAL L., DURAND A., FABRE L., HEINZ C., SOLARI M.-E., THIEBAULT S. (1996). Les variations du $\delta$ C13 sur une série de charbons de bois préhistoriques et historiques méditerranéens de $35000 \mathrm{BP}$ à l'actuel. Premiers résultats. Compte Rendu à l'Académie des Sciences de Paris, t. 323, série IIA : 323-324.

VIDAL L. (2000). Aménagement et mise en valeur des campagnes de la Protohistoire au Moyen Âge dans le sud de la France: l'exemple du Languedoc central et oriental, thèse de doctorat de l'Université de Montpellier III-Paul Valéry, 475 p., 282 fig.

VILLEDIEU F. (1986). Importations africaines, orientales et hispaniques à Marseille, Lyon, Arles et Narbonne. In : FÉVRIER $1986: 182-183$.

VITA FINZI C. (1969). The Mediteranean Valley : Geological changes in Historical Times, Cambridge University Press, Cambridge, 143 p..

WEGMÜLLER S. (1977). Pollenanalystische Untersuchungen zur spät- und postglazialen Vegetationsgeschichte der französischen Alpen (Dauphiné), Bern, 185 p..

WHITTAKER, C. R. (1976). Agri deserti. In : FINLEY 1976 : 137-165.

WILSON A. (1995). Water-power in North Africa and the development of the horizontal-wheel. Journal of Roman Archaeology, 8 : 499-510. 